Assessing the Cost of Financial Regulation

Douglas Elliott, Suzanne Salloy, and André Oliveira Santos 
IMF Working Paper

Monetary and Capital Markets

\title{
Assessing the Cost of Financial Regulation ${ }^{1}$
}

\section{Prepared by Douglas Elliott ${ }^{2}$, Suzanne Salloy, ${ }^{2}$ and André Oliveira Santos}

Authorized for distribution by Aditya Narain

September 2012

\section{This Working Paper should not be reported as representing the views of the IMF.} The views expressed in this Working Paper are those of the author(s) and do not necessarily represent those of the IMF or IMF policy. Working Papers describe research in progress by the author(s) and are published to elicit comments and to further debate.

\begin{abstract}
This study assesses the overall impact on credit of the financial regulatory reforms in Europe, Japan, and the United States. Long-term cost estimates are provided for Basel III capital and liquidity requirements, derivatives reforms, and higher taxes and fees. Overall, average lending rates in the base case would rise by 18 bps in Europe, 8 bps in Japan, and 28 bps in the United States. These results are similar to the official BIS assessments of Basel III and an OECD analysis, but lower as a result of including expense cuts and reductions in the returns required by investors. As a result, they are markedly lower than those of the IIF.

JEL Classification Numbers: G21, G24, G28, G32

Keywords: Basel III, Financial Regulation, Systemically Important Institutions, Banks Author's E-Mail Address: DElliott@brookings.edu, ASantos2@imf.org

\footnotetext{
${ }^{1}$ We are grateful for the guidance and comments provided by Jonathan Fiechter, Aditya Narain, Jodi Scarlata, and colleagues in the Monetary and Capital Market Department's Financial Sector Analysis division.

${ }^{2}$ Douglas Elliott is a Fellow at the Brookings Institute and is a consultant to the IMF on this project. Suzanne Salloy was a summer intern at the IMF when this paper was initiated.
} 


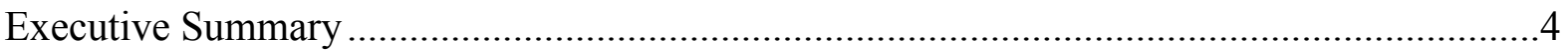

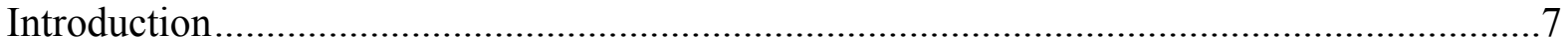

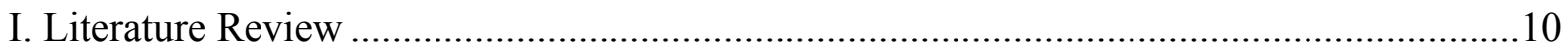

II. Qualitative Assessments of the Cost Impact of Regulatory Changes ..............................13

III. Quantitative Analysis of Stand-Alone Reforms ......................................................... 19

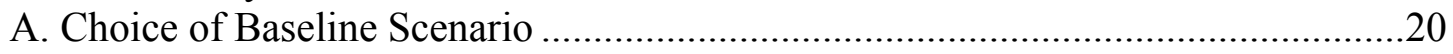

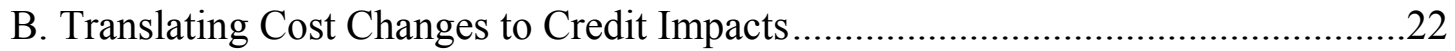

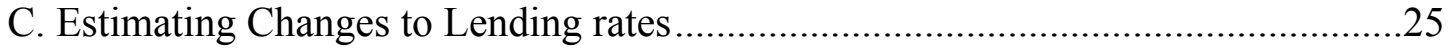

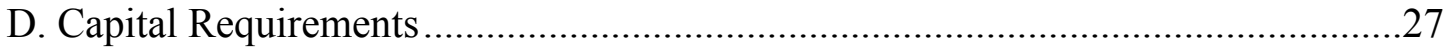

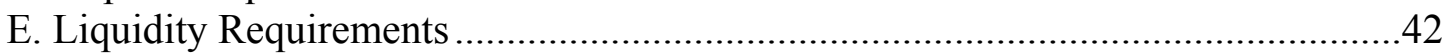

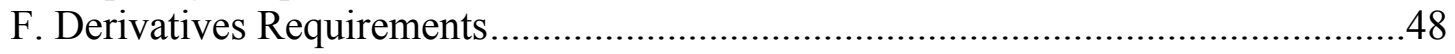

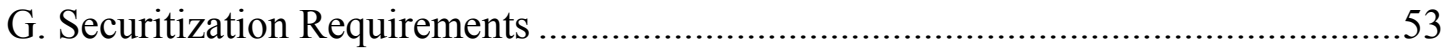

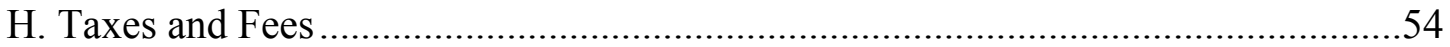

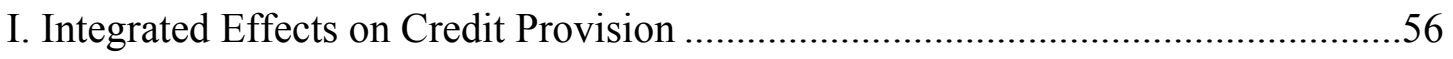

IV. Uncertainties and Areas for Further Research.........................................................66

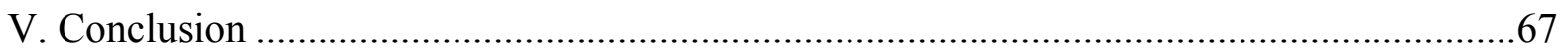

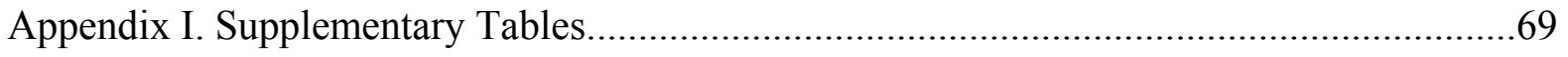

Appendix II. Assumptions for the Credit Pricing Equation............................................72

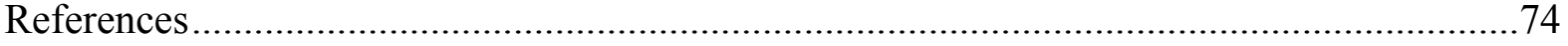

Tables

1. Basel III Impact on Credit and GDP Growth.........................................................13

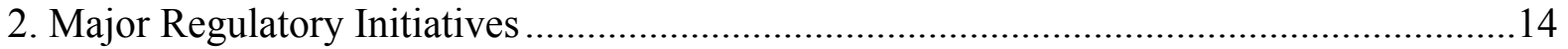

3. Impact of Major Regulatory Initiatives on U.S. Financial Institutions.............................15

4. Pro-forma Basel III Common Equity Tier 1 Capital Ratios by Region, End-2010 .............32

5. Planned Mitigating Actions by U.S., European, and Japanese Banks, ..............................35

6. Pro-forma Basel III Common Equity Tier 1 Capital Ratios by Bank Business...................36

7. Effects of Higher Capital Levels on Lending Rates ....................................................40

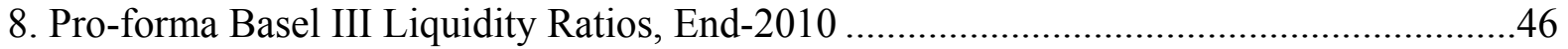

9. Estimated Effects of Liquidity Changes on Lending Rates ..........................................47

10. Effects of Derivatives Reforms on Banks per Year....................................................52

11. Estimated Effects of Derivatives Changes on Lending Rates ......................................53

12. Annual Fees and Taxes on European and U.S. Banks ..............................................56

13. Estimated Effects of Tax and Fee Changes on Lending Rates ...................................56

14. Cumulative Impact of Regulatory Reforms on Lending rates .....................................63

16. European, Japanese, and U.S. Banks in the Sample ............................................. 70

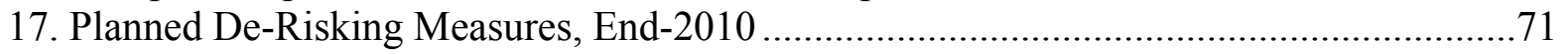


Figures

1. Effect of Basel III Changes on Common Equity Tier 1 Capital Ratios, .............................34

2. Effect of Basel 2.5 and III on Common Equity Tier Capital Ratios, ..................................38

3. Effects of Changes in Key Parameter Assumptions on Lending Rates ............................65

Appendixes

I. Supplementary Tables

II. Assumptions for the Credit Pricing Equation .......................................................... 72 


\section{EXECUTIVE SUMMARY}

Reforming the regulation of financial institutions and markets is critically important and should provide large benefits to society. The recent financial crisis underlined the huge economic costs produced by recessions associated with severe financial crises. However, adding safety margins in the financial system comes at a price. Most notably, the substantially stronger capital and liquidity requirements created under the new Basel III accord have economic costs during the good years, analogous to insurance payments.

There is serious disagreement about how much the additional safety margins will cost. The Institute of International Finance (IIF), a group sponsored by the financial industry, estimated the proposed reforms will reduce economic output in the advanced economies by approximately 3 percent during 2011-15. Official estimates suggest a much smaller drag.

Finding an intellectually sound consensus on the costs of reform is critical. If the true price is too high, reforms must be reassessed to improve the cost-benefit ratio. But, if reforms are economically sound, they should be pursued to increase safety and reduce the uncertainty about rules that creates inefficiencies and makes long-term planning difficult.

This study assesses the overall impact on credit of the global financial regulatory initiatives in, Europe, Japan, and the United States. It focuses on the long-term outcomes, rather than transitional costs, and does not attempt to measure the economic benefits of reforms. Academic theory is combined with empirical analyses from industry and official sources, plus financial disclosures by the major financial firms, to reach specific cost estimates. The analysis here does not address the significant adjustments triggered by the financial and Eurozone crises and the potential transitional effects of adjusting to the new regulations.

The study focuses principally on the effects of regulatory changes on banks and their lending. This is for three reasons: banks dominate finance; the reforms are heavily focused on them; and it is harder to estimate the effects on other parts of the system, such as capital markets. Loans, in particular, are a major part of overall credit provision and there is substantially greater data available on lending activities. Where possible, the study also looks at the effects of new regulations on securities holdings by banks and on securities markets.

Measuring the cost of financial reform requires careful consideration of the baselines for comparisons. They should incorporate the higher safety margins that would have been demanded by markets, customers, and managements after the financial crisis, even in the absence of new regulation. Some studies take the approach of assuming all the increases in safety margins are due to regulatory changes, exaggerating the cost of reforms.

A simple model is used to estimate the increase in lending rates required to accommodate the various reforms. The model assumes credit providers need to charge for 
the combination of: the cost of allocated capital; the cost of other funding; credit losses; administrative costs, and certain miscellaneous factors. The study establishes initial values for these key variables, determines how they would change under regulatory reform, and evaluates the changes in credit pricing and other variables needed to rebalance the equation.

Cost estimates are provided for capital and liquidity requirements, derivatives reforms, and the effects of higher taxes and fees. These categories were chosen after a detailed qualitative assessment of the relative impact of different reforms on credit costs. Securitization reform was initially chosen as well, but proved impossible to quantify.

Finally, an overall, integrated cost estimate is developed. This involves examining the interactions between these categories and including the effects of mitigating actions likely to be taken by the financial institutions as a result of the reforms in totality. This includes, for example, the room for expense cuts to counteract the need for price increases, to the extent that such cuts were not already included in stand-alone impact estimates.

Lending rates in the base case rise by 18 bps in Europe, 8 bps in Japan, and 28 bps in the United States, in the long run. There is considerable uncertainty about the true cost levels, but a sensitivity analysis shows reasonable changes in assumptions do not alter the conclusions dramatically. The results are broadly in line with previous studies from the official sector, partially because similar methodologies are employed. This paper finds similar first-order effects to the official BIS assessments of Basel III (BCBS (2010) and MAG (2010)) and the analysis at the OECD by Slovik and Cournède (2010). The cost estimates here are, however, markedly lower than those of the IIF.

\section{Three extensions of the methodologies from the official studies, though, lead to} substantially lower net costs. The base case shows increases in lending rates of roughly a third to a half of those found in the BIS and OECD studies, despite important commonalities in the core modeling approaches with these studies. First, the baselines chosen here assume a greater hike in safety margins due to market forces, and therefore less of a regulatory effect, than the OECD and IIF studies. (The BIS studies do not reach firm conclusions on the additional capital needs). Industry actions through end-2010 suggest that market forces alone would have produced reactions similar to what was witnessed to that point, even if no regulatory changes were contemplated.

Second, this paper assumes that banks will also react by reducing costs and taking certain other measures that have little effect on credit prices and availability, in addition to the actions assumed in the other studies. The official studies do not do so and the IIF study assumes a fairly low level of change. This accounts for 13 bps of cost reduction in Europe, 10 bps in Japan, and 20 bps in the United States. Third, this paper assumes that equity investors will reduce their required rate of return on bank equity as a result of the safety improvements. Debt investors are assumed to follow suit, although to a much lesser 
extent. The official studies assume no benefit from investor reactions, for conservatism, and the IIF assumes the benefits, although real, will arise over a longer time-frame than is covered by their projections.

There are important limitations to the analysis presented here. Transition costs are not examined, a number of regulatory reforms are not modeled, judgment has been required in making many of the estimates, the overall modeling approach is relatively simple, and regulatory implementation is assumed to be appropriate, therefore not adding unnecessary costs. Despite these limitations, the results appear to be a balanced, albeit rough, assessment of the likely effects on credit. Further research would be useful to translate the credit impacts into effects on economic output.

\section{Again, all of the analysis is based on the long-run outcome, not taking account of a transition being made in today's troubled circumstances. To the extent that bank capital or liquidity is difficult or very expensive to raise during the transition period - as they are currently in Europe, a reduction in credit supply would be expected and any increase in lending rates would be magnified, perhaps substantially. Deleveraging is clearly occurring at European banks under today's conditions in response to financial market, economic, regulatory, and political factors. It is impossible to tell whether any appreciable portion of this reaction is due to anticipation of the Basel III rules. Regardless of the transitional effects, it will be possible, over time, for banks to find the necessary capital and liquidity to provide credit, as long as the pricing is appropriate. Capital and liquidity will flow to banks from other sectors if the price of credit rises more than is justified by the fundamental underlying factors.}

The relatively small effects found here strongly suggest that the benefits would indeed outweigh the costs of regulatory reforms in the long run. Banks have a great ability to adapt over time to the reforms without radical actions harming the wider economy. 


\section{INTRODUCTION}

Reforming the regulation of financial institutions and markets is critically important and should provide large benefits to society. The recent financial crisis, from which the world is still recovering, underlined the huge economic cost that comes with recessions associated with severe financial crises. For this reason, policymakers around the world, including the leaders of the Group of 20, placed a high priority over the last few years on reforming the financial system.

However, adding safety margins in the financial system comes at a price. There are a few areas of financial reform, such as some of the measures to increase transparency, where the system's running costs may actually decrease as measures to increase safety also improve efficiency. Much more frequently, though, greater security has a cost during the non-crisis years when the wider safety margins have little short-term benefit. Most notably, the substantially stronger capital and liquidity requirements created under the new Basel III accord have economic costs during the good years that are analogous to insurance payments. In this case, the insurance is intended to substantially reduce the probability of future financial crises, their severity, and the damage to the wider economy resulting from them.

There is serious disagreement about how much the additional safety margins will cost. The Institute of International Finance (IIF, 2011) has projected that the proposed reforms will wipe away approximately 3 percent of the economic output of the advanced economies during 2011-15. Official estimates, particularly those from the Bank for International Settlements (BIS) Macroeconomic Assessment Group (MAG), suggest a reduction in Gross Domestic Product (GDP) in those countries that is much lower.

Finding an intellectually sound consensus on the costs of reform is critical. If the true price is too high, then reforms need to be restructured as necessary to improve the costbenefit ratio. On the other hand, if the reforms are economically sound, then they should be pushed forward to increase safety and reduce the uncertainty about future rules that creates inefficiencies and makes long-term planning difficult.

This study aims at assessing the overall impact on credit of the financial regulatory initiatives in Europe, Japan, and the United States. The study first reviews relevant academic theory. It then examines three principal sets of data sources: official sector analyses of the economic impact of reforms; disclosures by financial institutions of the pro-forma impact of Basel III rules; and reports by equity and debt analysts, industry associations, and consulting companies of the impact of the regulatory initiatives.

The study focuses on the long-term outcomes, rather than transitional costs, and does not attempt to measure the economic benefits of these reforms. Good policymaking requires true cost-benefit analyses and it would certainly be a mistake to ignore transitional 
costs. However, resource constraints required a narrower focus on the central question of the long-term effects on credit. Further research would be useful to translate the credit effects into their impacts on economic output.

Separate estimates are provided for Europe, Japan, and the United States. The economic and financial systems of these regions differ significantly, substantially altering the economic impact of the reforms. For example, the banking system in the United States is considerably smaller in relation to the size of its economy than is true in the other two regions. In addition, the specific reforms vary somewhat between regions and countries, even though there is a great deal of commonality in the overall direction of the changes and sometimes in the details. Despite divergences that are worthy of analysis, Europe is not broken down in order, for example, to analyze the United Kingdom and Switzerland differently.

The study goes into substantially more detail on the effects of regulatory changes on banking than on the rest of the financial system. This is partly because the actual changes are heavily focused on banks, as the cornerstone of the financial system, and partly because it is much harder to estimate the effects on, for example, capital markets with any degree of precision. The choice was also made to focus on regulatory changes that were specifically spurred by the financial crisis. This means excluding, for instance, Solvency II, the new European rules on capital and certain other safety margins for insurers, since it was in the works well before the financial crisis struck.

Further, the primary focus is on the loan business. This results from a combination of the high importance of loans in overall credit provision and the substantially greater data available on lending activities. Where possible, the study also looks at the effects of the new regulations on securities holdings by banks and on the markets for securities. In addition, the analytical approaches and overall findings related to bank lending are generally quite relevant to other forms of credit provision.

Measuring the cost of financial reform requires careful consideration of the baseline for comparisons. At first glance this might seem simple, since one can compare the new regulatory requirements with the old. However, this misses the crucial point that regulatory requirements are not necessarily the binding constraint. In particular, financial institutions often carry significantly stronger safety margins than the minimums required by the rules, as a result of their own desire to operate safely and because of pressure from the markets and rating agencies. Nor can it can be assumed that the additional buffers on top of the regulatory requirements will remain the same as in pre-crisis times. The crisis sharply altered perceptions of risk by bank managers, customers, counterparties, and investors. As a result, the appropriate buffers above regulatory minima have surely changed. 
Again, all of the analysis is based on the long-run outcome, not taking account of a transition being made in today's troubled circumstances. To the extent that bank capital or liquidity is difficult or very expensive to raise during the transition period - as they are currently in Europe, a reduction in credit supply would be expected and any increase in lending rates would be magnified, perhaps substantially. Deleveraging is clearly occurring at European banks under today's conditions in response to financial market, economic, regulatory, and political factors. It is impossible to tell whether any appreciable portion of this reaction is due to anticipation of the Basel III rules. Regardless of the transitional effects, it will be possible, over time, for banks to find the necessary capital and liquidity to provide credit, as long as the pricing is appropriate. Capital and liquidity will flow to banks from other sectors if the price of credit rises more than is justified by the fundamental underlying factors.

Several other areas of important uncertainty are not directly addressed in this study. First, it is assumed that regulations are implemented in an appropriate manner, thereby avoiding unnecessary costs. This is more likely to be true in the long run than when regulations are first introduced. Second, regulatory arbitrage and shifts of business to the "shadow banking" sector are seldom explicitly factored into the calculations here. Unlike the first point, such changes would generally decrease the cost of credit provision by circumventing costly regulatory reforms. Similarly, "gaming" of the system is only lightly addressed in this paper. It would also tend to decrease both the cost to banks and the overall effectiveness of reforms.

There are many areas for research to expand on the topics covered here. In addition to refining key findings presented here, other topics include analysis of transitional effects; potential impacts of regulatory arbitrage; changes in the role of less-regulated credit providers; the effects of insurance regulations; the impact on other regions of the world; a further breakdown of the effects on different types of borrowers, lenders, and types of transaction; and the inclusion of more categories of reform than those studied in detail here.

The review of the existing empirical and theoretical literature provides relevant cost estimates and benchmarks for the major categories of financial reform. The review includes methodologies and specific estimates provided by financial analysts and private sector consultants, in addition to reviews of more traditional academic research and economic analyses. The literature review is then combined with the authors' previous analyses and experience to assess qualitatively the relative importance of the cost impacts of the different categories of financial reform, such as changes to capital requirements.

Five categories of reform were initially selected for detailed quantitative analysis, based on the qualitative assessment. They are the most important and amenable to quantitative estimates. For each of the categories, cost estimates are presented based on external analyses, supplemented by calculations by the authors. The cost estimates are then translated into a 
common framework of changes in the average cost of credit for borrowers resulting from the reforms, since this is of most concern to the rest of the economy. There was sufficient information to evaluate the impact of most regulatory changes, except securitization reform, which proved impossible to quantify.

Finally, an overall, integrated cost estimate for the categories taken together is considered. This involves examining the interactions between these categories and including the effects of mitigating actions likely to be taken by the financial institutions as a result of the reforms in totality. This includes, for example, the room for expense cuts to counteract the need for price increases, to the extent that such cuts were not already included in standalone impact estimates.

\section{Literature REVIEW}

There are many academic analyses of the effects of capital requirements on lending behavior. The most theoretical models are useful for drawing some broader lessons about the optimum design of capital regulation but make too many simplifying assumptions to be very helpful with the specifics of the analysis in this study. Empirical studies of the effects of historical changes in capital requirements, for their part, find it difficult to fully control for other factors occurring at the same time, making it hard to draw more than broad conclusions from them. There are many fewer academic analyses of the likely impact of liquidity requirements and virtually no studies on the cost effects of the other major regulatory changes, with the exception of changes in taxation or fees.

\section{Equity and credit analysts and international management consulting firms with expertise in the financial sector have evaluated the likely cost impact of reforms. These firms have a strong incentive to perform these analyses. Most crucially, these can substantially change the appropriate prices of the stocks and bonds of firms in the sector. As a result, there are a host of analyses, of varying qualities, addressing questions directly relevant to this study. ${ }^{3}$ They are helpful, in part because they incorporate guidance from the financial institutions as to how they plan to adjust to various reforms. In addition, major international management consulting firms have also provided detailed analyses of what they think financial institution managements need to do in order to respond to the regulatory reforms. They are also useful in pointing out the likely responses by managements and the considerable range of reactions beyond simply increasing prices to customers.}

\footnotetext{
${ }^{3}$ One has to be aware of potential biases toward the over-estimation of regulatory costs in reports about the financial system written by employees of major financial institutions, but this is offset, and perhaps more than offset, by the pressures for financial analysts to be positive about the prospects of the industry they follow. If cost estimates by analysts are too negative, it makes it difficult for them to recommend buying shares in these firms, which puts them at odds with the managements they follow, and upon whom they rely for information. Many investment funds in this sector are specialists and would also not welcome excessively negative views that would hurt the stocks that they own.
} 
Official bodies have published cost-benefit analyses of some of the important regulatory changes, particularly the capital and liquidity reforms proposed in Basel III. These analyses have reported low effects of the capital and liquidity reforms on the economy, with the benefits from higher financial stability outweighing the cost incurred in terms of lost output.

\section{Findings of Comprehensive Studies}

The study that provides the most detailed analysis of the overall cost impact of comprehensive financial reforms is IIF (2011). The Institute of International Finance is an association representing over 400 financial institutions across the world. Its study, although admirably comprehensive and detailed, shows a far larger cost to financial reform measures than seems plausible. For instance, their model predicts that the price of credit in the United States will average almost 5 percentage points higher on average over the period 2011-15 as a result of the regulatory changes alone. This encompasses all forms of loans, including mortgages and shorter-term credit. Overall, they estimated that GDP in major economies would be about 3 percent smaller in 2015 than they would be without the effects of comprehensive financial reforms.

This study differs substantially from IIF (2011). One major difference, which comes through in multiple ways, is the focus on the long-term effects while the IIF looks primarily at the transition effects in the short- to medium-term. Beyond that, there are a number of other different technical choices. There are four areas in particular where divergent views appear to have the greatest impact:

- $\quad$ First, the IIF baseline appears to correspond more with the levels of safety margins held pre-crisis than it does with the levels banks would choose to hold in light of the lessons learned from the financial crisis. This can make a large difference since the levels of capital and liquidity were clearly far too low pre-crisis, which would have been corrected to a very considerable extent by market forces with or without new regulation. This means that the IIF study ascribes a considerable amount of the cost of shifting to a saner financial system to regulatory change rather than to market-driven adjustments.

- $\quad$ Second, the IIF assumes that the expected return demanded by investors in bank securities is heavily influenced by the volume of securities being issued, at least in its main scenario. It takes some increase in expected returns to lure investors to absorb a large amount of issuance, but the assumed magnitude of that effect seems too big. This matters, as it appears to be an important driver of their results.

- $\quad$ Third, there is greater scope for cost-cutting by banks than the IIF assumes. This is of somewhat lesser importance numerically, but is still enough of a difference to matter. 


\section{Slovik and Cournède (2011) at the Organisation for Economic Cooperation and} Development (OECD) estimated effects well below those found in IIF (2011). They used a simple banking model that assumes that bank funding costs would rise by the difference between the starting cost of capital and the starting cost of debt, multiplied by the amount of new capital required. This increased cost is directly passed through as an increase in interest rates on loans. Thus, their model excludes any decrease in the returns required by investors from the presumably safer banking system and assumes no expense costs or any other adjustments besides a simple rise in loan pricing. They also assumed that banks would maintain the same discretionary capital buffers above regulatory minimums as these minimums increased, despite referencing previous studies that showed banks do tend to lower their discretionary buffers under these circumstances. Despite making a number of key assumptions that should tend to overstate the impact on lending rates, they still concluded that those spreads would rise by much less than the IIF estimates. They then went on to use an OECD macroeconomic model to translate the credit spread increases into declines in expected economic growth. Their conclusion was that the major economies would be about 0.75 percent smaller after five years, rather than 3 percent smaller in the IIF's estimate.

\section{Finally, BCBS (2010) estimated that the Basel III capital and liquidity changes would} reduce the steady-state level of economic activity by 0.6 percent in total, or 0.08 percent annually, if spread over the eight-year transition period. This study did not examine the other regulatory changes, but it is likely that the capital and liquidity changes taken together account for a significant majority of the costs. It also estimates the liquidity changes by looking solely at the Net Stable Funding Ratio (NSFR) requirements and not the Liquidity Coverage Ratio (LCR), although its technique appears likely to capture most of both effects. Key assumptions in BCBS (2010) include a full pass-through of capital and funding costs to loan rates, no reduction in operating expenses, no increase in non-interest sources of income, no credit rationing, no changes in the cost of capital and debt arising from higher capital and liquidity ratios, a possible reduction in the liquidity requirements arising from compliance with the capital requirements, a 15 percent return-on-equity (ROE), and a 100 bps yield difference between illiquid and liquid assets and long and short liabilities.

\section{Thus, as shown in Table 1, previous studies differ greatly in their cost estimates. ${ }^{4,5}$}

Because of these major differences in outcome and methodology, it has been necessary to go beyond these studies to look at analyses that examine different parts of the overall picture and to build up from there.

\footnotetext{
${ }^{4}$ It should be noted that a number of simplifying assumptions had to be made to put the results on a reasonably consistent basis for the table, given their disparate approaches.

${ }^{5}$ MAG (2010) estimated- loan spreads that are slightly higher over a period of 35 quarters than then ones estimated by BCBS (2010) and slightly lower over a period of 48 quarters.
} 
Table 1. Basel III Impact on Credit and GDP Growth

\begin{tabular}{|c|c|c|c|c|c|c|c|c|}
\hline \multirow{2}{*}{$\begin{array}{l}\text { Basel III impact } \\
\text { Zone }\end{array}$} & \multicolumn{3}{|c|}{$\begin{array}{l}\text { Impact on credit } \\
\text { spreads } \\
\text { (bps) }\end{array}$} & \multicolumn{3}{|c|}{$\begin{array}{c}\text { Impact on annual GDP } \\
\text { growth } \\
(\%) \\
\end{array}$} & \multirow{2}{*}{$\begin{array}{l}\text { Credit } \\
\frac{\text { (bps) }}{\text { Global }}\end{array}$} & \multirow{2}{*}{$\begin{array}{l}\text { GDP } \\
(\%) \\
\text { impact }\end{array}$} \\
\hline & Europe & Japan & U.S. & Europe & Japan & U.S. & & \\
\hline IIF 2012-2019 & 328 & 181 & 243 & -0.40 & -0.30 & -0.10 & 281 & -0.20 \\
\hline IIF 2011-2015 & 291 & 202 & 468 & -0.60 & -0.80 & -0.60 & 364 & -0.70 \\
\hline OECD 5 years transition & 54 & 35 & 64 & -0.23 & -0.09 & -0.12 & 53 & -0.16 \\
\hline BIS Long-term (capital) 1/ 2/ 3/ & 52 & N.A. & 52 & -0.07 & N.A. & -0.03 & 52 & -0.06 \\
\hline BIS Long-term (liquidity) 3/ 4/ & 25 & N.A. & 25 & -0.03 & N.A. & -0.03 & 25 & -0.03 \\
\hline BIS Long-term (combined) 3/ 5/ & 66 & N.A. & 66 & -0.08 & N.A. & -0.04 & 66 & -0.08 \\
\hline \multirow{4}{*}{\multicolumn{9}{|c|}{$\begin{array}{l}\text { 1/ BIS estimates an increase in credit spread of } 13 \text { bps for each one point increase in the ratio of Tangible } \\
\text { Common Equity to Risk-Weighted Assets, but does not estimate the total required change in that ratio. } \\
\text { For broad consistency with the IIF and OECD figures, a } 4 \text { point change in the ratio is assumed. } \\
\text { 2/ U.S. and European figures for needed capital increases are assumed to be the same for this table. } \\
\text { 3/ BIS estimates the permanent, steady-state change in level of GDP. For comparison with the other studies, } \\
\text { the cost is spread over } 8 \text { years. }\end{array}$}} \\
\hline & & & & & & & & \\
\hline & & & & & & & & \\
\hline & & & & & & & & \\
\hline \multicolumn{9}{|c|}{$\begin{array}{l}\text { 4/ BIS does not provide a breakdown by region on the credit spread effects of liquidity changes, } \\
\text { so global figures are used for both regions. }\end{array}$} \\
\hline
\end{tabular}

\section{Qualitative Assessments OF The COST ImPaCt OF Regulatory Changes}

Ranking the categories of financial reforms by their likely impacts allows one to select a subset on which to focus. Reforms are in process across a very wide range of financial activities, in response to the many flaws and risks that were exposed by the severe financial crisis. Table 2 lists the major categories and sub-categories of legislation and regulation of the financial sector undertaken in response to the crisis.

It is necessary to focus the quantitative analysis on the key areas of reform. The breadth of the changes, across multiple geographies, renders it impossible to cover all the reforms in a reasonable timeframe. In order to focus the quantitative analysis on the key areas, the reforms are grouped into larger categories and then assessed by their relative importance on a qualitative basis. This assessment is made separately for each geographical region and also broken down by the major classes of financial institutions and markets.

Table 3 shows the qualitative assessment for the United States of the impact on the major categories of financial institutions. Similar tables are shown in the appendices for Europe and Japan. Table 3 condenses the qualitative assessment into a simple scale running from +10 to -10 , where +10 represents a category of reform that is likely to create a major increase in costs for the relevant type of financial institution. Negative numbers indicate that those institutions would likely benefit from a decrease in costs, or from an increase in revenues that more than covers the additional costs. For example, changes to capital requirements, which are heavily concentrated on the highly regulated financial institutions, particularly banks, should drive some business to insurers, other non-bank financial institutions, and to the capital markets. This would be offset only slightly by the effects of capital changes on these other types of financial institutions, leading to a substantial benefit for them. 
Table 2. Major Regulatory Initiatives

\begin{tabular}{|c|c|}
\hline Higher capital requirements & $\begin{array}{l}\text { Higher overall capital } \\
\text { Higher quality capital } \\
\text { SIFI buffer } \\
\text { Capital conservation buffer } \\
\text { Counter-cyclical capital requirements } \\
\text { Penalty for combining banking and assurance } \\
\text { Many changes to the specific requirements }\end{array}$ \\
\hline Higher liquidity requirements & $\begin{array}{l}\text { Liquidity coverage ratio } \\
\text { Net stable funding ratio } \\
\text { Liquid asset definition } \\
\text { Stress test } \\
\text { Off-balance sheet commitments } \\
\text { Money market fund regulation } \\
\text { Local restrictions }\end{array}$ \\
\hline Expansion of the regulatory perimeter & $\begin{array}{l}\text { Applying bank-like rules to some non-banks } \\
\text { HF- Alternative Fund Managers }\end{array}$ \\
\hline Enhanced consumer protection regulation & Consumer loans in USA \\
\hline Tightening of derivatives regulation & $\begin{array}{l}\text { Standardized trades } \\
\text { Central counterparties for clearing of standardized trades } \\
\text { Higher capital and collateral requirements } \\
\text { Increased transparency } \\
\text { Post-trade disclosures }\end{array}$ \\
\hline Accounting changes & $\begin{array}{l}\text { Tightenning of standards for what can be off the balance sheet } \\
\text { Conforming IASB and GAAP } \\
\text { Fair value measurement } \\
\text { Hedge accounting }\end{array}$ \\
\hline Changes to securization regulation & $\begin{array}{l}\text { Skin-in-the game requirements } \\
\text { Change to initial and ongoing disclosure requirements } \\
\text { Underwriting standards }\end{array}$ \\
\hline Tougher regulation of credit rating agencies & $\begin{array}{l}\text { EU oversight } \\
\text { Increased legal risk for the agencies in the US } \\
\text { Greater SEC oversight in the US } \\
\text { Restricted use in regulation }\end{array}$ \\
\hline Structural changes to banks and limitations on bank activities & $\begin{array}{l}\text { Resolution and recovery plans } \\
\text { Volcker rule in the US } \\
\text { Limitation in the US on derivatives dealing by banks } \\
\text { Vickers commision structural changes in UK banking }\end{array}$ \\
\hline Changes in regulation of compensation and corporate governace & $\begin{array}{l}\text { EU limitations on and regulation of compensation } \\
\text { US rules for changes in incentive compensation }\end{array}$ \\
\hline Higher taxes or fees facing financial institutions & UK bank tax \\
\hline Changes in crisis resolution regimes & $\begin{array}{l}\text { Dodd-Frank in the US } \\
\text { International coordination in crisis prevention and coordination }\end{array}$ \\
\hline Compensation & $\begin{array}{l}\text { Guidelines on risk alignment and governance } \\
\text { Deferrals and claw-backs } \\
\text { Link to capital conservation } \\
\text { Limits for state-assisted firms } \\
\text { Shareholder say on pay }\end{array}$ \\
\hline
\end{tabular}


The categories of reform in Table 3 are listed in rough order of importance, based on the authors' qualitative assessments. However, there is no formula to go from the figures in the table to the position in the listings. The ordering of the list is purely a convenience for the reader, given the subjectivity involved in establishing it. In general, the ordering should be clear by a simple inspection. The rationales for the qualitative assessments in Table 3 are shown after the table. It should be noted that it is assumed that the implementation of regulations will be appropriate. Some of these areas are highly complex and the economic costs could be higher if there are execution problems.

Table 3. Impact of Major Regulatory Initiatives on U.S. Financial Institutions

\begin{tabular}{|c|c|c|c|c|c|c|c|}
\hline & \multicolumn{2}{|c|}{ Commercial Banking } & \multirow{2}{*}{$\begin{array}{l}\text { Investment } \\
\text { Banking }\end{array}$} & \multirow{2}{*}{$\begin{array}{l}\text { Universal } \\
\text { Banking }\end{array}$} & \multirow{2}{*}{$\begin{array}{c}\text { Life } \\
\text { Insurers }\end{array}$} & \multirow{2}{*}{$\begin{array}{l}\text { Non-bank } \\
\text { Financials }\end{array}$} & \multirow{2}{*}{$\begin{array}{l}\text { Capital } \\
\text { Markets }\end{array}$} \\
\hline & Large & Small & & & & & \\
\hline Higher capital requirements & 10 & 10 & 10 & 10 & -7 & -8 & -10 \\
\hline Higher liquidity requirements & 7 & 4 & 10 & 8 & -5 & -8 & -10 \\
\hline Tightening of derivatives regulation & 8 & 3 & 10 & 8 & -2 & -3 & -5 \\
\hline Accounting changes & 3 & 3 & 3 & 3 & 1 & 6 & 3 \\
\hline Changes to securitization regulation & 2 & 3 & 2 & 2 & 1 & 4 & 3 \\
\hline Enhanced consumer protection regulation & 5 & 5 & 2 & 3 & 1 & 7 & 2 \\
\hline Expansion of the regulatory perimeter & -3 & -3 & -1 & -2 & 0 & 7 & 2 \\
\hline Higher taxes or fees facing financial institutions & 3 & 2 & 3 & 3 & 1 & 3 & -1 \\
\hline Changes in crisis management and resolution regimes & 4 & 0 & 3 & 3 & -1 & -1 & -2 \\
\hline Tougher regulation of credit rating agencies & 1 & 1 & 1 & 1 & 1 & 2 & 2 \\
\hline Structural changes to banks and activity limits & 2 & -1 & 3 & 2 & 0 & -1 & -2 \\
\hline Changes in regulation of compensation and governance & 0 & 0 & 0 & 0 & 0 & 0 & 0 \\
\hline
\end{tabular}

- $\quad$ Higher capital requirements. Capital is a key input, and an expensive one, for most banking activities, as confirmed by the later quantitative assessments. The required equity capital for banking activities will increase several-fold in the United States, compared to prior regulation, once Basel III is implemented. The result is to increase costs substantially for U.S. banks across the board. On the other hand, non-banks, with rare exceptions, are not facing appreciably higher capital requirements. This will improve their competitive position for those activities in which they compete with banks. In particular, some credit activity may move to the capital markets, which are facing essentially no increases in capital requirements.

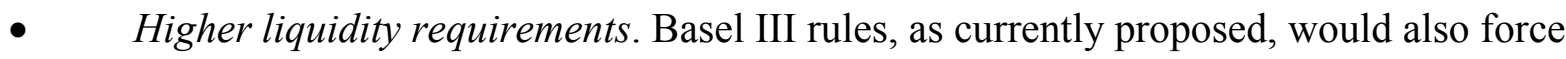
U.S. banks to shift their asset-liability management to favor shorter asset maturities and longer liability maturities, both of which are expensive. ${ }^{6}$ Like the capital changes, this heavily affects the core of banking activities and, therefore, has a high impact. This impact is likely to be somewhat less, however, for the commercial banking portion of the business, which can access a substantial amount of stable deposits that are favored by the liquidity rules. Therefore, commercial banking, particularly at smaller banks, should be considerably less affected than investment banking.

\footnotetext{
${ }^{6}$ As discussed below, it is highly likely that there will be significant changes in the Basel III liquidity requirements before they are fully implemented.
} 
Universal banks would fall in between, given their split of business between commercial and investment banking. As with capital, non-bank financial institutions are largely unaffected by Basel III or similar changes and therefore should benefit from a movement of business in their direction.

- $\quad$ Tightening of derivatives regulations. The Dodd-Frank Act requires regulators to take a series of actions to push business away from customized derivatives towards exchange-traded derivatives and away from bilateral counterparty arrangements and into central clearinghouses. In general, it will be mandatory for standardized types of derivatives to be exchange-traded and centrally cleared. Customized derivatives will carry higher capital charges for banks and bank affiliates and collateral will often be required from counterparties where it was not needed before. Derivatives are a major category of financial activity in the United States, and many other banking activities rely on derivatives for hedging; therefore, changes of this magnitude will have major impacts on banks. For the most part, bank costs will increase and some of their higher-margin revenue sources will move to low-margin standardized forms. Some of this business will shift to the various non-bank financial institutions, with capital markets gaining the most, once again. Banks are likely to recoup some of their losses from additional business conducted with these entities, however. Insurers and nonbank financials will suffer some of the same losses as the banks, to an extent sufficient to reduce their net benefit, but not to eliminate it completely.

- Accounting changes. Changes in the Generally Accepted Accounting Principles (GAAP) used for U.S. accounting will almost invariably make U.S. financial institutions look less attractive and require more capital. The latter effect is because much of U.S. regulatory accounting automatically follows GAAP and other parts are heavily influenced by changes to GAAP. The most painful changes are probably those that make it considerably harder to move transactions off-balance sheet, inspired in part by the problems created by Structured Investment Vehicles (SIVs) that, in retrospect, should have been treated as on-balance sheet. The accounting changes should hit most financial institutions, with somewhat less effect on insurers and somewhat more on other non-bank financials, which generally relied much more on wholesale funding from vehicles like SIVs. Although this category of reform ranks relatively high on the list, it is not nearly as significant in its cost implications as changes to capital and liquidity requirements that affect the core of what financial institutions do or the major changes to derivatives markets.

- $\quad$ Changes to securitization regulations. Securitization reforms are aimed at increasing transparency and trying to incentivize the firms that put together the securitizations to care about the quality of their securitizations. This meshes with reforms in other areas such as regulation of the rating agencies and increases in capital standards for securitizations under Basel III. It is difficult to be sure of the magnitude of the impacts, since much will depend on the details in this area. However, it already seems clear that a large portion of the market will be exempted in the United States from 
some requirements, on the basis of guarantees from Fannie Mae and Freddie Mac. In general, it appears that banks will be modestly affected and the presumption is that securitizations will be harder and more costly to do, which would increase their costs. However, it is possible that restoration of faith in the securitization market could ultimately reduce costs for banks by allowing them to resume the more active use of those markets. Non-bank financial institutions are shown as more affected, since some of them have made very heavy use of securitizations in the past.

- $\quad$ Enhanced consumer protection regulations. Commercial banks in the United States are likely to be considerably affected over time by the newly established Consumer Financial Protection Bureau (CFPB). The presumption is that it will be an active agency that will generally be focused on consumer interests, even when that raises the costs for banks. Also, some actions that it takes would probably reduce revenue potential by making potentially profitable products unworkable for the banks. The industry clearly views the CFPB as a major threat to profitability of some lines of business and they may be right. Investment banks should be less affected since they sell fewer retail products, most of which would remain under Securities and Exchange Commission (SEC) supervision anyway. Many non-bank financial institutions will find themselves with substantial federal regulation for the first time, which is why they are expected to experience the largest impact.

- $\quad$ Expansion of the regulatory perimeter. There is always a question of which firms should be heavily regulated and which can be left outside the regulatory perimeter and subjected to a lesser degree of control. It has been agreed for many years that banks and insurers need to be within the perimeter. Investment banks were not included, but largely now are, as a result of the crisis. The Dodd-Frank Act did not do much directly about bringing "shadow banking" within the perimeter, but the Financial Stability Oversight Council has considerable power in this area and the CFPB does as well in areas that touch on consumer protection. Any expansion of the perimeter will bring greater costs and limitations to those firms that find themselves newly inside it, which would provide a relative benefit to banks as a result of creating a more level playing field.

- $\quad$ Higher taxes or fees facing financial institutions. Deposit insurance fees in the United States have increased considerably in response to losses at the Federal Deposit Insurance Corporation as a result of the financial crisis. The formula for calculating fees has also been altered so that most of the increase comes at the expense of the larger banks. There are also various proposed fee increases at the SEC and other regulatory bodies, which should raise costs in the industry. Finally, the U.S. Administration has proposed a Financial Crisis Responsibility Fee that was originally pegged at about US\$10 billion a year and was subsequently reduced to about US $\$ 3$ billion a year after estimated taxpayer losses from the financial rescues fell sharply. However, there appears to be little chance that this will pass through Congress. 
- $\quad$ Changes in crisis management and resolution regimes. The Dodd-Frank Act, complemented by international efforts coordinated through the Financial Stability Board (FSB) in Basel, is clearly intended to make it considerably easier to deal with large, troubled financial institutions and to reduce the chance that government support would be provided to aid bondholders and counterparties. This should add administrative expenses and operational limitations for the large U.S. banks and may raise the interest rates they have to pay on their liabilities as a result of a lessened potential for government aid. These cost burdens would produce at least a modest competitive advantage for other credit providers.

- $\quad$ Tougher regulation of credit rating agencies. The Dodd-Frank Act encourages greater SEC oversight of the rating agencies, requires more transparency, and raises their legal liabilities. All of this is intended to ensure that they do a better job in the future of providing unbiased and accurate ratings. This is not likely to have a strong effect on the financial industry's costs or revenues, although it may very modestly raise the cost of ratings and the work required to procure them and may slightly reduce revenues by making rating agencies less flexible about meeting requests from the banks.

- $\quad$ Structural changes to banks and activity limits. Relatively little structural change is being required by Dodd-Frank, with the exception of the so-called Volcker Rule to eliminate proprietary trading and related activities and through some changes in where derivatives business can be housed within a banking group. These changes are not inconsequential, but they act on the periphery of the banking business. They will also produce some relative winners, probably modestly increasing the competitiveness of smaller banks that had never had the ability to subsidize some of their core activities with profits from proprietary trading. Capital markets should benefit as some business is forced out of the banking groups.

- $\quad$ Changes in regulation of compensation and governance. Compensation and governance changes required by legislation and regulation are relatively minor in the United States. Where they are likely to have the most effect, such as in forcing better management of compensation arrangements, they generally work in favor of the banks by encouraging an ongoing shift towards approaches that discourage unreasonable risk-taking and by helping hold down overall employee compensation. At the same time, the new regulations do not appear draconian and are unlikely, of themselves, to lead to an exodus of talent from the heavily regulated financial institutions towards hedge funds and other competitors.

Overall, the reforms fall into three broad groupings. Capital and liquidity requirements should have a major impact on costs and profitability for banks and should thereby confer some significant competitive advantages on non-banks of various kinds. At the other end of the spectrum, a number of categories of reforms should have relatively little effect on costs, and, in the middle, there are some that will be significant, but do not rise to the level of effect 
of the first grouping. These conclusions are broadly true for all three regions studied, although the details certainly vary among the regions. The high importance of capital and liquidity makes sense as good management of these items is central to banking.

Compliance costs were not addressed initially, but appear unlikely to rise to the significance of the most important categories. It is true that additional compliance costs could well rise to multi-billion dollar figures, but this must be viewed in the context of bank assets in the three regions in the range of US\$50 trillion. Further, many of these costs would be one-time charges that would be amortized over many years and the changes will often provide value to bank managements by giving them a more detailed understanding of their own positions and risks.

It is critical to bear in mind that these qualitative assessments are rough, subjective, and intended for a limited purpose. They are only used to focus the remainder of the work and not in an attempt to rank their overall regulatory importance or their overall virtues. The exact rankings, especially in any one column, are of no significance to the remainder of the conclusions.

\section{Quantitative Analysis of Stand-Alone Reforms}

Five categories of reform were selected for further analysis based on the qualitative assessments below. They are the capital and liquidity requirements, derivatives and securitization regulations, and taxes and fees. ${ }^{7}$ These five categories capture most of the total cost impact of regulatory reforms. In addition, the other categories are difficult to quantify and their impacts will be sufficiently small in relation to the aggregate effects of the five chosen categories that the conclusions here should remain largely valid. The expansion of the regulatory perimeter is likely to work in the opposite direction to all the others, generally aiding banks and hurting non-banks, so its exclusion should partially offset the failure to include the other areas.

The changes in capital requirements virtually all stem from Basel III. Most, if not all, of the world's significant financial centers were represented in the deliberations of the Basel Committee on Banking Supervision (Basel Committee or BCBS) on Basel III. As a result, the leaders of the G-20 have endorsed the changes and all significant financial centers have agreed to implement Basel III. The Basel III capital rules are very comprehensive, so that countries have generally seen little need to go beyond that framework, except that a few, such as Switzerland, have chosen to create still higher capital requirements using the same overall approach.

\footnotetext{
${ }^{7}$ Abouhossein and Ranjan (2012) estimate that two thirds of the 7 percentage point reduction in the projected 2013 ROE in global investment banks are associated with Basel III capital and liquidity rules while the other one third is related to the Dodd-Frank Act, the Independent Commission on Banking, and the French proposal.
} 
The creation of new liquidity requirements, or changes to the existing ones, also reflect strongly those in Basel III. It should be noted that few nations had formal liquidity requirements, although it was always part of the task of supervisors to make at least a subjective judgment about liquidity levels. As a result, the Basel III liquidity standards will generally determine liquidity requirements going forward. Previous versions of the Basel accord did not contain liquidity requirements, so this is a very new area for the committee.

There is no global agreement on changes to derivatives regulation, but the United States and Europe are broadly on the same track in their proposed reforms. Asian countries are expected to act once the dominant derivatives centers settle on their regulations. On both sides of the Atlantic, the intent is to push derivatives away from customized trades and into standardized formats wherever possible and to have those transactions executed on exchanges and cleared through central clearinghouses. For those transactions where customization remains sensible, counterparty risks are to be reduced by requiring higher capital from financial institutions and by raising or instituting collateral requirements for counterparties.

\section{Similarly, there is no global agreement on securitization regulation, but the United} States and Europe are in broad agreement. It is unclear at this point what Asian regulators might do, but the securitization markets in most of Asia are relatively small in comparison. Securitization reforms are intended to ensure that new securitizations are more transparent and that those entities that put together the securitizations have "skin in the game" so that they are not indifferent to the ultimate success or failure of the securitization. The level of that skin in the game appears likely to be 5 percent on both sides of the Atlantic, although much of the market in the United States will be exempted because of guarantees by Fannie Mae and Freddie Mac or because the underlying mortgages meet certain stricter standards. Reforms in other areas are also intended to make securitizations safer, such as through regulation of the rating agencies and increases in capital standards for securitizations under Basel III.

Changes in taxation and fees for financial entities may vary greatly across the world. There is considerable disagreement across the globe, particularly in the vexed area of potential taxes on financial transactions. The latter is being considered quite seriously in Europe, but has been rejected by the United States and a number of other countries. Changes in taxes and fees to date have been quite specific to individual countries, such as the increases in deposit insurance fees promulgated in the United States.

\section{A. Choice of Baseline Scenario}

A key consideration in any quantitative study of the effect of regulatory changes is the baseline against which to compare. This would be relatively simple if financial institutions always ran exactly at the minimum levels required by regulation or even if they always 
maintained the same buffer above those minimums, regardless of economic and financial market conditions. However, this is clearly not true.

Financial institutions decide their target capital and liquidity levels based on a number of factors, not just regulatory requirements. Managements will choose their levels of safety margins so as to meet the maximum of: (i) the regulatory requirements plus whatever chosen buffer the institution prefers to hold to lower the risk of regulatory intervention if things go wrong; (ii) the economic capital that their own risk models tell them they need in order to minimize risks of bankruptcy or other bad outcomes; (iii) the level the rating agencies demand for the institution to maintain its targeted credit rating; and (iv) the level that counterparties and financial markets demand.

The financial crisis substantially increased the safety margins demanded under all four methods, not just the requirements of regulators. Banks' own economic risk models have been adjusted to reflect substantially higher risk perceptions, in addition to automatic increases as the data from the financial crisis became part of the historical database. Rating agencies clearly became more conservative, even aside from their perceptions about how regulators might change requirements. Finally, counterparties, financial markets, and customers have shed the considerable complacency that they exhibited prior to the financial crisis.

The fair test, therefore, would be to compare expected post-reform levels of safety margins, such as capital ratios, with what those levels would be in the absence of regulatory changes, but taking account of changes in the behavior of other parties as a result of the financial crisis. Unfortunately, the latter levels cannot be observed and some subjective judgment is necessary to determine the appropriate baseline. However, it is imperative to reflect changes in safety margins demanded by non-regulatory constituencies, including banks' internal risk managers, even though it requires judgment to estimate the figures. Otherwise, the calculations would unfairly penalize regulatory changes for costs that would have been incurred anyway as a result of the demands of other constituencies.

The baseline assumptions are shown in the individual sub-sections dealing with the different regulatory changes. In general, end-2010 figures on capital and liquidity in the United States, Japan, and Europe are used as a reasonable approximation of what market forces would have demanded even without regulatory changes. This has the potential of understating the effects of regulation, since some in the industry argue that a substantial portion of the reaction to Basel III was already included in the capital and liquidity levels by then. ${ }^{8}$ This does not appear to be the case, however. There has been clear market pressure for

\footnotetext{
${ }^{8}$ For comparison, end-2009 ratios of capital to risk-weighted assets were approximately 0.5 to 1.5 percentage points lower, depending on the region.
} 
banks to carry substantially higher capital ratios, post-crisis, and for the quality of capital to be increased. This has been most obvious in Europe, where the end-2010 figures for the European banks probably overstate the regulatory impact since markets are clearly demanding more capital and liquidity than those banks had at end-2010, at least in aggregate. For Japan, the end-2010 figures seem reasonable and consistent with the other continents, although it is less clear what a reasonable baseline is for that nation. A few figures illustrate the rationale for using end-2010 ratios for the three regions. Financial markets became much more focused on the ratio of tangible common equity to total assets as a result of the financial crisis. Yet, even by the end of 2010, the Basel III equivalent of this ratio was only at about 3 percent in Europe and Japan and a bit over 5 percent in the United States. ${ }^{9}$ It is very unlikely that financial markets would be comfortable with lower ratios than this in Europe and Japan in the long run. This also appears unlikely in the United States, where asset holdings are generally riskier, and the accounting creates higher levels of the ratio than under International Accounting Standards.

\section{It is even less likely that new requirements for minimum liquidity levels had a} substantial impact on bank balance sheets by end-2010. The Basel liquidity rules take effect after a multi-year delay and it is already widely believed that there will be significant changes in the rules on the liquidity coverage ratio and probably even more substantial revisions to the net stable funding ratio rules. Since the balance sheet adjustments could, in practice, be put in place by banks within a couple of years, the long transition periods and regulatory uncertainty make it improbable that banks had already acted on this in any major way by end-2010. Indeed, there is little anecdotal evidence that they have. On the other hand, they have presumably already reacted to market forces resulting from the crisis. Thus, end2010 levels appear to be a good baseline for liquidity.

\section{Similarly, the other major categories of proposed regulatory changes are unlikely to} have been reflected in banks' financial statements by end-2010. Transition periods and regulatory uncertainties in these areas also appear to have given banks enough breathing space that they have not dramatically altered their activities yet.

\section{B. Translating Cost Changes to Credit Impacts}

Higher costs for banks and other credit providers clearly will affect credit pricing and availability, but not through a direct 100 percent pass-through. Like other industries under pressure, credit providers will respond in a variety of ways, with the exact mix of actions dependent on specifics of the cost increases and of the competitive situation of the

\footnotetext{
9 Tier 1 common equity under Basel III appears to be a reasonable proxy for the tangible common equity ratio and may even capture investors' intent better.
} 
credit providers. There are eight broad categories of bank responses to cost increases in this paper:

- $\quad$ Absorbing the costs by lowering returns to shareholders. In the long run, credit providers can only absorb any additional costs if the expected returns to shareholders remain at or above the target returns required by them, otherwise the sector will shrink over time as capital is withdrawn. In a reasonably efficient market, a reduction in required returns is only likely to be the case if the increase in cost is associated with some other factor that makes investors willing to accept a lower return over time. A number of the regulatory reforms should have exactly this effect. For example, higher capital requirements should reduce the probability of failure and also damp down the volatility of profits. This increased safety should induce investors to lower their return requirements.

- $\quad$ Reducing funding costs. All else equal, banks could respond by paying less for their deposits and borrowed funds. Fund providers that do not benefit from guarantees ought to reduce their required interest rates at least marginally to reflect the greater safety provided by higher bank capital, better liquidity, and the benefits of other reforms. There may also be room for banks to decrease the rates paid on retail deposits, even when they are guaranteed. Money market funds and other available products are not perfect substitutes for retail deposits, which means that cost pressures on the banking industry could result in some rate decreases. ${ }^{10}$ In practice, the new minimum liquidity requirements are likely to raise average funding costs by more than these factors reduce them, but the net increase should still be smaller than in the absence of the safety benefits and the ability of banks to squeeze deposit rates.

- $\quad$ Reducing expenses. Industries that come under external pressure almost invariably reduce their costs as one response to the threat, as seen to a significant extent already in the financial industry. A substantial portion of the cost of credit provision comes from administrative and marketing expenses, where there is considerable room to cut expenses if necessary. In addition to reductions in expense ratios at individual banks, there are likely to be market share gains by the more efficient banks, lowering the average expense ratio for the industry as a whole.

- $\quad$ Decreasing the expected credit losses. Credit providers can alter the terms and conditions under which they lend, in order to reduce the probability of a credit loss and the size of any resulting loss. This can occur without necessarily cutting back on marginal loans per se. For example, loans to businesses often contain covenants by the borrower that must be met to keep the loan in place, such as maintaining a certain

\footnotetext{
${ }^{10}$ See Elliott (2009 and 2010a) for a discussion of the competitive situation of the retail deposit market in the United States. It is notable that movements in retail deposit rates are not as highly correlated with money market fund rates as one might expect, indicating that they are somewhat distinct markets.
} 
minimum level of net worth or annual income. Technically the lender could call the loan if such covenants are breached, perhaps reducing their loss by exiting before more damage occurs. More commonly, the negotiating leverage provided by this right is used to renegotiate the loan to improve pricing for the lender or to force the borrower to agree to actions to remedy the problems they face. Including tougher covenants up-front is one way to reduce the expected losses on such a loan.

- $\quad$ Limiting the regulatory impacts through technical means. In some cases, there is scope for a credit provider to reduce the effect of a regulatory change by taking specific actions designed to meet the particular challenge. For example, improving data collection and modeling efforts may allow a firm to justify a lower risk weighting under the internal modeling approach. Less technically, it may be possible to meet a client's credit needs through a somewhat different transaction, such as by decreasing the maturity of a loan modestly to make it a short-term asset or by making a commitment to lend rather than disbursing funds up-front. For that matter, there may be new circumstances where securitizations or outright loan sales may make sense. This broad category would also be where much of the activity would occur that policymakers may consider "gaming" the system. Credit providers will be looking for the optimal structure through which to offer a given product under the rules that are then applicable. Sometimes this will have consequences different from those desired by policymakers.

- $\quad$ Rationing credit. Credit providers could also choose to make fewer loans by rejecting those loan applications that fail to meet newly heightened credit standards. This could be done at the individual loan level or by making a decision to withdraw from lines of business that do not meet minimum profitability criteria.

- $\quad$ Raising prices for credit. Finally, of course, credit providers can simply charge more for their loans. This option will be limited by competitive market conditions within the banking industry and in regard to other types of credit providers.

- $\quad$ Restructuring their businesses. Many credit providers are in the process of rethinking what business lines they wish to be in and how they manage those businesses. In the end, a combination of the above actions may be necessary to construct a portfolio of business lines that fit together to optimize the overall profitability of the organization. Such restructuring will also include strategic decisions to sell or buy businesses or to merge with other financial firms or to sell the entire organization.

\section{The likely reactions of credit providers to the regulatory changes are discussed below} under each of the categories of reform and also under the final section on quantification, which looks at some overall responses to the combined effects of regulation. 


\section{Estimating Changes to Lending rates}

The effects on lending rates of higher capital levels and other safety margins can be estimated using a loan pricing formula. ${ }^{11}$ The core of any lending decision boils down to a fairly simple mathematical formulation to determine whether a requested credit provides sufficient return to merit making the loan:

$$
L^{*}(1-t)>=\left(E^{*} r_{e}\right)+\left(\left(D^{*} r_{d}\right)+C+A-O\right) *(1-t)
$$

where:

$L=$ effective interest rate on the loan, including the annualized effect of fees;

$t=$ marginal tax rate for the bank;

$E=$ proportion of equity backing the loan;

$r_{e}=$ required rate of return on the marginal equity;

$D=$ proportion of debt and deposits funding the loan, assumed to be the amount of the loan minus $E$;

$r_{d}=$ effective marginal interest rate on $D$, including indirect costs of raising funds, such as from running a branch network;

$C=$ the credit spread, equal to the probability-weighted expected loss;

$A=$ administrative and other expenses related to the loan;

$O=$ other income and expense items related to the loan.

In simple terms, the rate on the loan needs to cover the cost of capital and other funding sources, any expected credit losses, plus administrative expenses. This preliminary hurdle rate may be reduced by other benefits to the bank from making the loan. For example, many of the largest commercial banks in the United States have built their investment banking arms in part on the propensity of corporations to direct their investment banking business, which is generally lucrative, to those banking groups that also supply them with loans. As a result, loans to large companies prior to the crisis were often underpriced on a stand-alone basis, in recognition of the relationship benefits.

Versions of this simple formula are an important building block in all of the studies described earlier, because it allows researchers to translate costs arising from regulatory reforms into loan rate increases and GDP changes. ${ }^{12}$ Among others, Elliott (2009 and 2010a), BCBS (2010), MAG (2010), and Slovik and Cournede (2011) all use this pricing model (also named accounting-based approach) with small variations and IIF (2011)

\footnotetext{
${ }^{11}$ Portions of the following discussion are taken from Elliott (2009). See also King (2010) for a similar approach.

12 This is especially true in economic and econometric models featuring neither bank capital nor bank liquidity.
} 
uses a closely related model..$^{13}$ The formula has the flexibility to capture many key attributes of credit provision. For example, the varying risks of different loan classes can be captured by creating a weighted average capital requirement and a weighted average credit cost. Elliott (2010a) applied the formula to different types of loans, borrowers, and lenders to explore the differential impact of capital requirements on different types of credit. This study focuses on aggregate credit provision in order to simplify the analysis. Further research could use the same approach to examine various categories of lending. Once loan rate increases are obtained, the impact of regulatory reforms on GDP can then be estimated.

For simplicity and conservatism, the analysis here assumes that any additional capital requirements will be met with common equity, rather than preferred equity or other securities. Some securities besides common equity can count as capital, within strict limits, if they meet certain criteria. These securities are generally cheaper than common equity, so their inclusion in the analysis could slightly decrease the estimated cost of regulatory changes. However, it is clear that most banks will not be raising additional non-common forms of capital in response to the new regulations, in part because they already have substantial amounts outstanding that were issued under the previous, less stringent, capital rules. Similarly, the banking industry appears to have little need to issue additional Tier 2 capital, the weakest form of capital that is still allowed under Basel III. Therefore, the cost of any such capital-raising is not estimated here. In sum, this analysis focuses solely on Tier 1 capital requirements and assumes any new capital is in the form of common equity.

Regulatory reforms will change a number of the variables in the loan pricing formula, forcing the banking industry to make offsetting adjustments to one or more other variables. For example, higher proportions of capital would require a higher price for credit, except to the extent offset by other adjustments, such as a lower cost of equity demanded by investors, reflecting reduced risk, or a reduction in administrative expenses at the bank. In the remaining sections, there is no treatment of lending under uncertainty and, therefore, no impact of any potential offsetting adjustments on the credit risk of different borrowers. In addition, the risk of credit rationing for less creditworthy borrowers is not analyzed in detail, although, as noted below, it would be relatively limited. Adding both uncertainty and credit rationing would add complexity to the analysis, but the broad conclusions would still remain intact.

In general, the analysis here suggests the required increases in credit pricing are low enough that credit availability should not be significantly reduced in the aggregate, as the market should be willing to bear the higher price. However, there will doubtless be

\footnotetext{
${ }^{13}$ Individual country studies that build on the pricing equation above include Koop et al. (2010), Schanz et al. (2011), de-Ramon et al. (2012), for instance.
} 
some types of loans where competition from non-banks will make it impossible for banks to competitively offer credit at the prices necessary to produce the required return.

The results are insensitive to the base case assumptions for a number of the variables. The initially assumed rates for credit costs, administrative costs, and other income and expense do not influence the marginal effect of changes in the variables examined in this paper. For example, starting with an assumed credit spread of 3 percent, instead of 1 percent, simply causes the necessary loan rate to increase by that 2 percentage point difference. The effect of requiring more capital is the same in both cases. This is fortunate, since it is difficult to know what the equilibrium levels are likely to be for these variables. It would be possible to show a simpler version of the equation that condensed the three variables into one aggregate variable to emphasize this, but it seemed likely that readers would benefit from seeing the individual pieces.

\section{Capital Requirements}

\section{Minimum capital requirements for banking groups are sharply increased under}

Basel III. One of the lessons from the recent financial crisis is that banks need to hold significantly higher levels of capital. Therefore, the Basel Committee members, with the ultimate endorsement of the G-20 leaders, raised the minimum common equity capital ratio from, in practice, 2 percent of risk-weighted assets to 7 percent, which includes a 2.5 percent "conservation buffer." Banks with capital below the basic 4.5 percent ratio can be taken over by regulators. Banks above this level but below the 7 percent target will have serious operating limitations, including limits on compensation and on payments to shareholders.

The minimum quality of capital is also raised by Basel III. Another lesson of the crisis was that some financial instruments, and some types of assets, were not actually available to protect banks. For example, subordinated debt had been viewed as an effective form of capital, albeit one that provided weaker protection than common equity. The theory was that subordinated debtholders could be hit with losses without doing harm to constituencies that were of concern to regulators, such as depositors, senior debtholders, etc. In practice, very few regulators felt that they could allow such losses in the widespread and severe financial crisis experienced in 2008-9. The signaling and legal effects concerning the health of the troubled bank, and the potential to trigger a drying up of funding for other banks that might become troubled, were viewed as too severe to be worth the benefits of having subordinated debtholders shoulder some losses. Similarly, some types of assets, such as tax loss carryforwards or minority stakes in non-bank financial institutions, were difficult to monetize, in

part due to the severity of the crisis. As a result, Basel III drops subordinated debt, and some other securities, from the definition of capital and limits the ability of certain assets to be counted when calculating core common equity. 
Basel III capital requirements remain based primarily on risk-weighted assets (RWA). The key tests look at the ratio of capital to an adjusted size of total assets that reflects the presumed risk levels of the various assets. Many government obligations are treated as riskless by being given a zero-percent risk-weighting and therefore do not require any capital. Standard loans have a 100 percent risk-weighting, so that a bank owning only such loans as its assets would have risk-weighted assets equal to its total assets. Most mortgages are weighted at 50 percent. There are specific weights for many other asset categories as well.

Many risk weights are increased quite substantially under Basel III compared to Basel II, especially for trading account assets. The crisis also demonstrated that risk-weightings were often considerably too low compared to the actual risk of the assets. Some risk weights are directly increased under Basel III, while others rise because of changes to the formulas for how to calculate risk weights, especially for trading assets. The modifications for trading assets are generally in place already as part of a package of intermediate changes, known as Basel 2.5, which were agreed upon while the Basel III Accord was still in development.

Systemically Important Financial Institutions (SIFIs) will have an incremental capital requirement. On top of the otherwise required minimum, the largest and most important banking groups will have required minimum capital to RWA ratios of 0.5 to 2.5 percentage points above those applied to other banks. This can even rise to 3.5 percentage points if a SIFI is perceived to be growing its risks excessively despite already being subject to the 2.5 percentage point incremental requirement.

A new leverage ratio will generally not be the binding constraint on capital, but provides a safety net to ensure RWA calculations do not produce excessively large balance sheets. Basel III, for the first time, will introduce a straight leverage ratio as an additional minimum requirement. This leverage ratio is essentially just the level of capital divided by the total asset size, although there are adjustments to reflect off-balance sheet items and certain unfunded commitments. Most observers believe that this ratio will seldom be the binding one, since it is set low enough that the tests using RWAs should normally produce higher capital requirements. However, it would help to guard against a situation where banks held overly large quantities of seemingly low-risk assets which then proved to carry higher risk than was understood. A topical example of this might be the large holdings of sovereign debt of Eurozone countries, which had a risk-weighting of zero when acquired. The leverage ratio will undergo a "parallel run" period from 2013-17 during which it is not mandatory to remain above the minimum ratio, before it becomes a hard requirement in 2018. (Public disclosure of the ratios will be required starting in 2015).

In theory, under idealized conditions, adding equity capital does not increase bank costs. Modigliani and Miller (1958) proved that, under specific conditions, including perfect 
markets and no distortions induced by government policy, the proportion of a firm's funding coming from equity was immaterial to its weighted average cost of funds. ${ }^{14}$ This is because investors in equity and debt do not charge as much for supplying funds to a safe company as they do to a less safe one. Intuitively, this effect translates into investors accepting a lower expected return in consideration for the reduced risk and volatility resulting from higher capital levels and lower probability of default. Modigliani and Miller showed that increasing a firm's safety by switching from debt towards equity results in a reduction of the cost of each unit of equity and each unit of debt that exactly counteracts the cost increase from having more units of equity, which will always be more expensive than debt because of its inferior position in liquidations.

In practice, though, higher equity levels do increase a bank's costs. There are two significant distortions created by public policy that interfere with the offsetting mechanism described by Modigliani and Miller. First, virtually all jurisdictions provide a tax advantage to debt issuance by allowing corporate deductions for interest payments, but not for dividends. ${ }^{15}$ Therefore, the after-tax weighted cost of funding does go up as the portion of equity capital rises. In the first instance, this is purely a private cost, not a societal one, since it represents an increase in taxes paid to the government. From the point of view of the bank, however, it does create a cost increase which should prompt it to take offsetting actions of some kind, whether charging more for services, cutting expenses, or whatever. This creates effects on the larger economy.

\section{A second policy distortion is that there are a host of explicit and implicit guarantees of} bank liabilities. For instance, when deposits are guaranteed by the government, then deposit rates will be very insensitive to the relative safety of the bank. An increase in equity will not create a significant offsetting decrease in the rate demanded by depositors. ${ }^{16}$ This insensitivity of deposit rates could be offset by risk-based pricing of deposit insurance premiums, however those systems that do incorporate this mechanism tend to do so very crudely and seldom fully reflect the change in risk. Beyond deposits, debt investors appear to believe, with some reason, that certain banks are "too big to fail" and may therefore receive government aid in a crisis that eliminates or reduces the potential for debt-holder losses. Such implicit guarantees have a similar effect of lowering the benefits of increased safety that come from higher equity levels.

\footnotetext{
${ }^{14}$ See Modigliani and Miller (1958).

${ }^{15}$ Belgium is an exception. It provides banks with a tax break on equities in order to offset the tax advantage they forego by not issuing debt.

${ }^{16}$ There may be a small decrease in required deposit pricing, as depositors may still mildly prefer to be with a safer bank, for a variety of reasons, including being part of a wider relationship with the bank that may be sensitive to its creditworthiness.
} 
There may also be agency costs and market imperfections that increase equity costs. Some researchers believe that the cost of raising equity is significantly higher than pure theory would dictate. ${ }^{17}$ For example, there can be negative signaling effects when a firm chooses to issue equity since it may indicate that management believes the market price is higher than warranted by the firm's prospects. This would be less of an issue if many banks are raising equity and are doing so as a result of regulatory changes, but it is not entirely eliminated, since banks have other ways to respond, such as by cutting back on their size. A bank with over-priced equity would presumably be more likely to choose equity issuance rather than shrinkage.

\section{Different analysts make different assumptions about how much the increase in safety reduces the costs of switching to equity from debt. The more careful analysts generally} assume there is some offset, with the most common assumption being that the return on equity and debt demanded by investors adjusts to be about halfway ( 50 percent) between the complete offset assumed by Modigliani and Miller and a complete absence of any offset, which would mean no change in demanded returns. One of this report's authors earlier estimated a 50 percent offset for the United States based on a rough numerical analysis of tax effects and the likely reactions of investors in terms of reduced required returns on equity and debt, taking account of explicit and implicit guarantees on the liabilities (Elliott 2009). Miles, Yang, and Marcheggiano (2010) came to a similar conclusion based on a more extensive analysis. They found that, under simplified assumptions, U.K. banks showed a ModiglianiMiller pass-through of 45 percent under one test (linear specification) and 75 percent under another (log speficiation). In the end, there simply is not enough data available to conclusively determine the pass-through and too many factors have to be estimated, such as implicit guarantees, in order for theory to give an exact answer. A 50 percent pass-through appears to be a reasonable estimate that, if anything, is likely to modestly understate the long-term pass-through.

The degree of offset matters significantly to estimates of the effects of capital increases on credit costs and economic growth. As discussed below, a significant difference between the IIF's findings and those of others is that it assumes a smaller offset, in substantial part because it focuses on the transition and not the long run. Of course, a complete offset would render the question of the pass-through of higher equity costs essentially moot, since total costs would remain constant. However, it is a very small minority of analysts, if any, who believe there would be a complete offset.

There are multiple ways banks can meet Basel III's much tougher capital standards. Equity could be raised through retaining earnings or by new issuance, assets could be shrunk

\footnotetext{
${ }^{17}$ Researchers include, for instance, Myers (1984) and Myers and Majluf (1984) who proposed the pecking order hypothesis in the capital structure.
} 
to reduce the denominator of the capital ratios, or assets with higher risk-weightings could be replaced with assets with lower risk-weightings. Credit pricing is likely to rise and availability to fall, as banks need more incentives to hold assets on their balance sheets due to the rise in their total funding costs. The real question is the magnitude of the impacts. The main debates in this regard are about how much it would cost to raise large sums of capital and, therefore, the effects on the cost of providing credit, and about how any increased costs would be divided between expense cuts, reductions in credit availability, and increases in credit pricing.

\section{The new Basel regulations affect European, Japanese, and U.S. banks differently.}

Table 4 and Figure 1 summarize the disclosures by 21 banks in the United States, 38 European banks, and 6 Japanese banks of their pro-forma Basel III common equity Tier 1 capital ratios, supplemented with estimates from Da Silva et al. (2011) and Cannon et al. (2010) for banks that have not provided any disclosure. ${ }^{18,19}$ Both Table 4 and Figure 1 show that the impact of the increase in RWAs and the qualification standards for capital (deductions) arising from Basel III reduces common equity Tier 1 capital ratios by 2.5-3 percentage points on average. However, the effects of increases in RWAs and deductions on U.S., European, and Japanese banks are asymmetrical. The effect of increases in RWAs is larger in U.S. banks than in European and Japanese banks on average while the effect of the deductions against capital is higher in Japanese banks than in European and U.S. banks. ${ }^{20}$ As a result of the two effects, pro-forma Basel III common equity Tier 1 capital ratios for European banks are larger than in U.S. and Japanese banks on average. ${ }^{21,22}$ Finally, Table 4 also shows that European banks plan to rely more on mitigating actions to comply with the Basel III minimum required ratios than U.S. banks. However, this also seems to be

\footnotetext{
${ }^{18}$ The disclosures by the banks are incomplete in many cases, not homogeneous, and reported in different documents and ways. This implies that there is some interpretation involved to understand the effects of the new Basel III capital rules on the banks.

${ }^{19}$ In practice, sell-side equity and debt analysts will rarely go too far out on a limb in making their own calculations of something this complex and managements are equally eager to keep invalid calculations from gaining currency. Thus, there tends over time to be considerable guidance provided by managements to the analytical community on technical calculations such as these.

${ }^{20}$ Hansen et al. (2012) find similar asymmetric effects of Basel 2.5 and III on RWAs.

${ }^{21}$ Samuels et al. (2012) also find that European banks have higher projected 2013 Basel III core Tier 1 capital ratios than U.S. banks.

${ }^{22}$ If public sector capital injections in European banks are excluded, pro forma Basel III common equity Tier 1 capital ratios for European banks would be slightly lower than in U.S. banks on average. As Basel III only grandfathers the public sector capital injections until 2018, most European banks with public sector capital injections plan to repay them before 2018. This would lead to a reduction in their pro forma Basel III common equity Tier 1 capital ratios. Indeed, Dayal et al. (2011) reported pro forma Basel III core Tier 1 capital ratios that exclude public sector injections, resulting in lower pro forma Basel III core Tier 1 capital ratios for European banks (5.8 percent) than for U.S. banks (6.7 percent) as of end-2010.
} 
the result not only of new Basel III regulations but also of the current European financial crisis, which makes raising new capital unattractive, creating a premium for mitigation activities.

Figures from the European Banking Authority (EBA, 2012) suggest Basel III capital ratios may be modestly smaller than shown in Table 4. A study by the EBA of balance sheet figures as of end-June 2011 for European banks (EBA 2011) concluded that the ratio of common equity Tier 1 capital to RWA would average about 6.6 percent if Basel III were fully applied at that point. This compares to the 7.1 percent average shown in Table 4 . This difference could result from the passage of time, although this is unlikely to have been a major factor. More likely it results from the common definition across the banks imposed by EBA or from a sample bias in the figures underlying Table 4, given the reliance on voluntary disclosures. ${ }^{23}$

\section{Table 4. Pro-forma Basel III Common Equity Tier 1 Capital Ratios by Region, End-2010 \\ (In percent)}

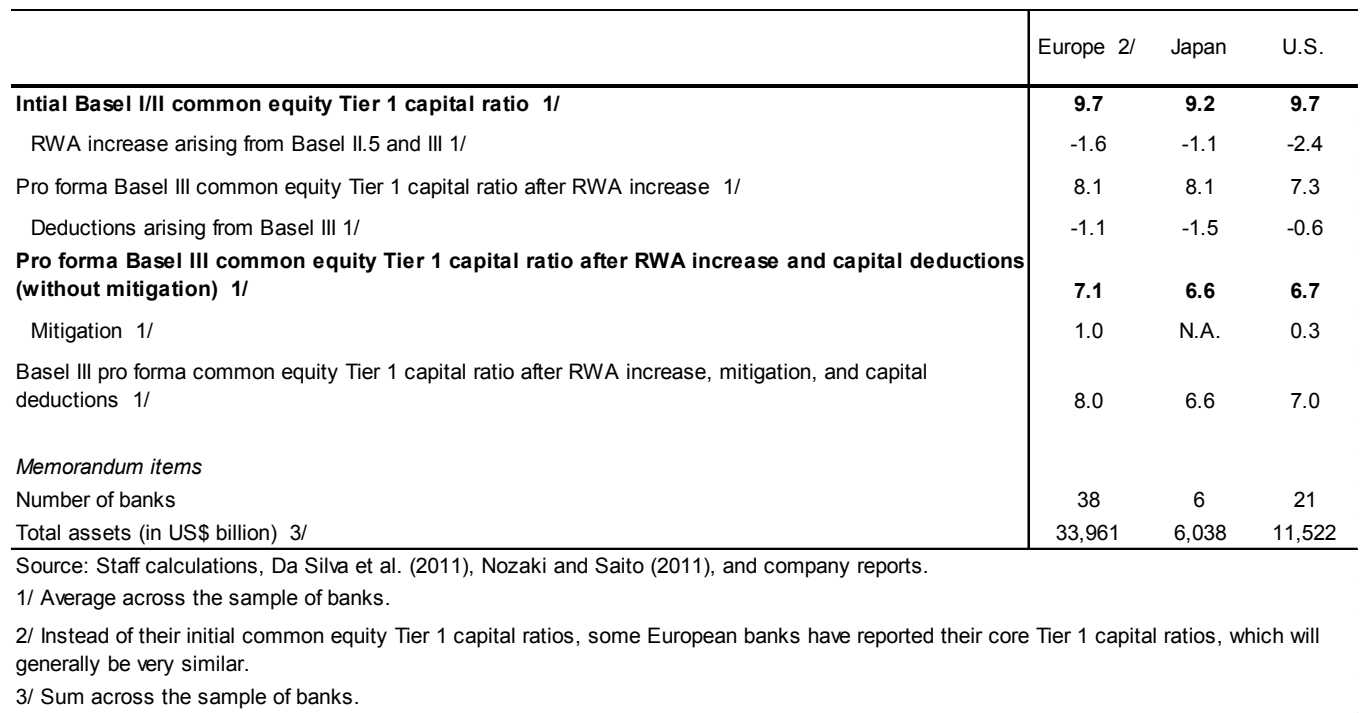

\section{Planned mitigating actions in Table 4-which does not include planned capital} raising - are de-risking measures. Table 5 lists 4 categories of mitigating actions that are intended to reduce RWAs, including asset run-offs, asset disposals, asset impairments, and

\footnotetext{
${ }^{23}$ In a sample of 103 global and regional banks from advanced and emerging economy member jurisdictions, BCBS (2012) reported that the impact of Basel 2.5 and Basel III on a pro forma basis is a reduction in common equity Tier 1 capital ratio from 10.2 percent to 7.1 percent on average, as of end-June 2011, which is broadly consistent with estimates shown here.
} 
other actions such as RWA optimization. ${ }^{24}$ The first three mitigating actions aim at offsetting increases in RWAs of particular assets that make them no longer viable for banks to hold. They do not necessarily lead to deleveraging if there is no reduction in the associated funding, no haircuts in the run-off or disposal of assets, and only a change in the asset composition. The fourth mitigating action includes certain technical measures that can be taken to reduce the RWAs by using better data and calculation methodologies.

\footnotetext{
${ }^{24}$ As seen on Table 5, most banks do not classify taking asset impairments as capital mitigation, because the impairment reduces capital at the same time as it reduces the balance sheet value of the asset.
} 
Figure 1. Effect of Basel III Changes on Common Equity Tier 1 Capital Ratios, End-2010

(In percent)

A. Effect of RWA Increases on Common Equity Tier 1 Capital Ratios

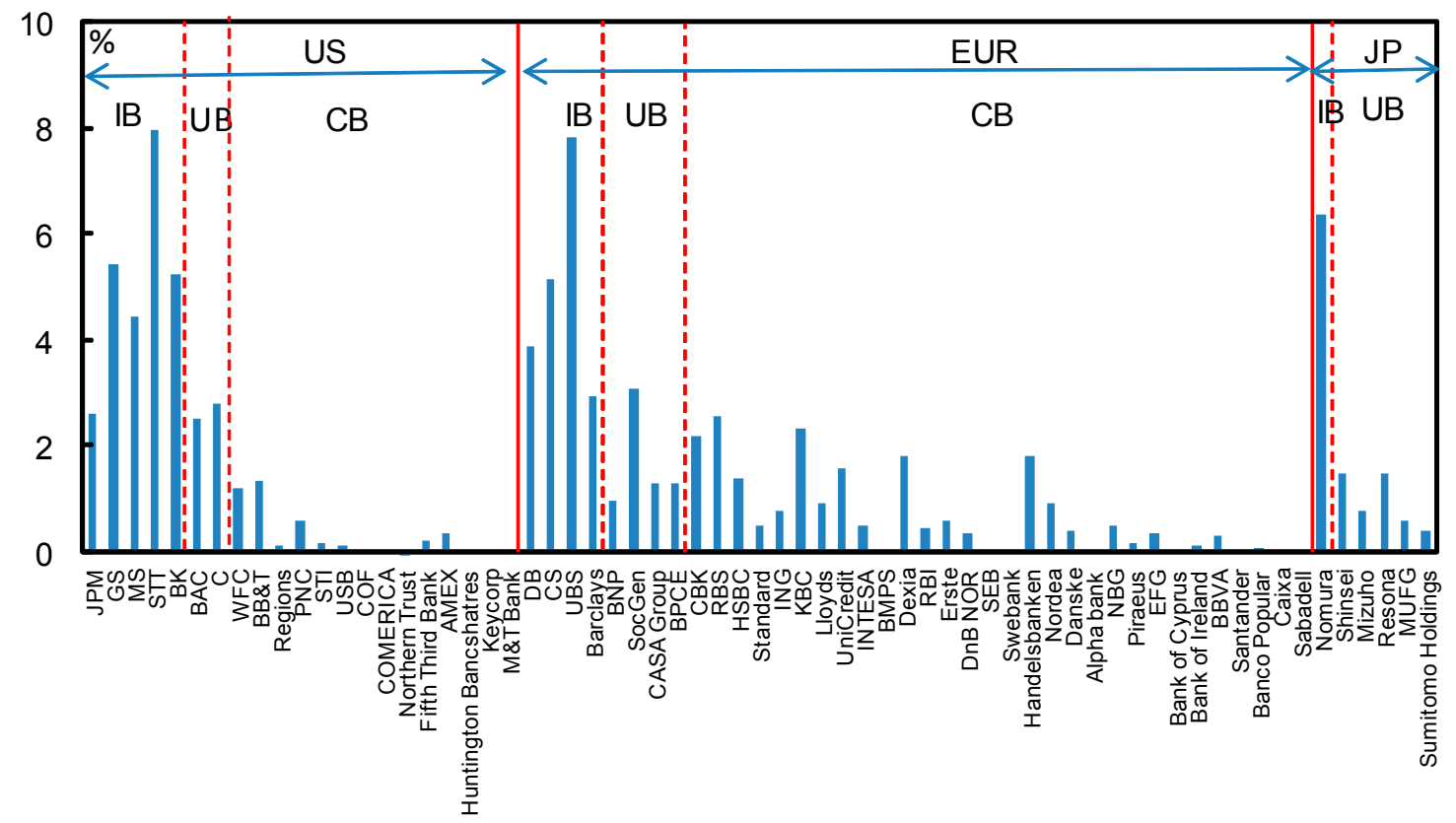

B. Effect of Deductions on Common Equity Tier 1 Capital Ratios

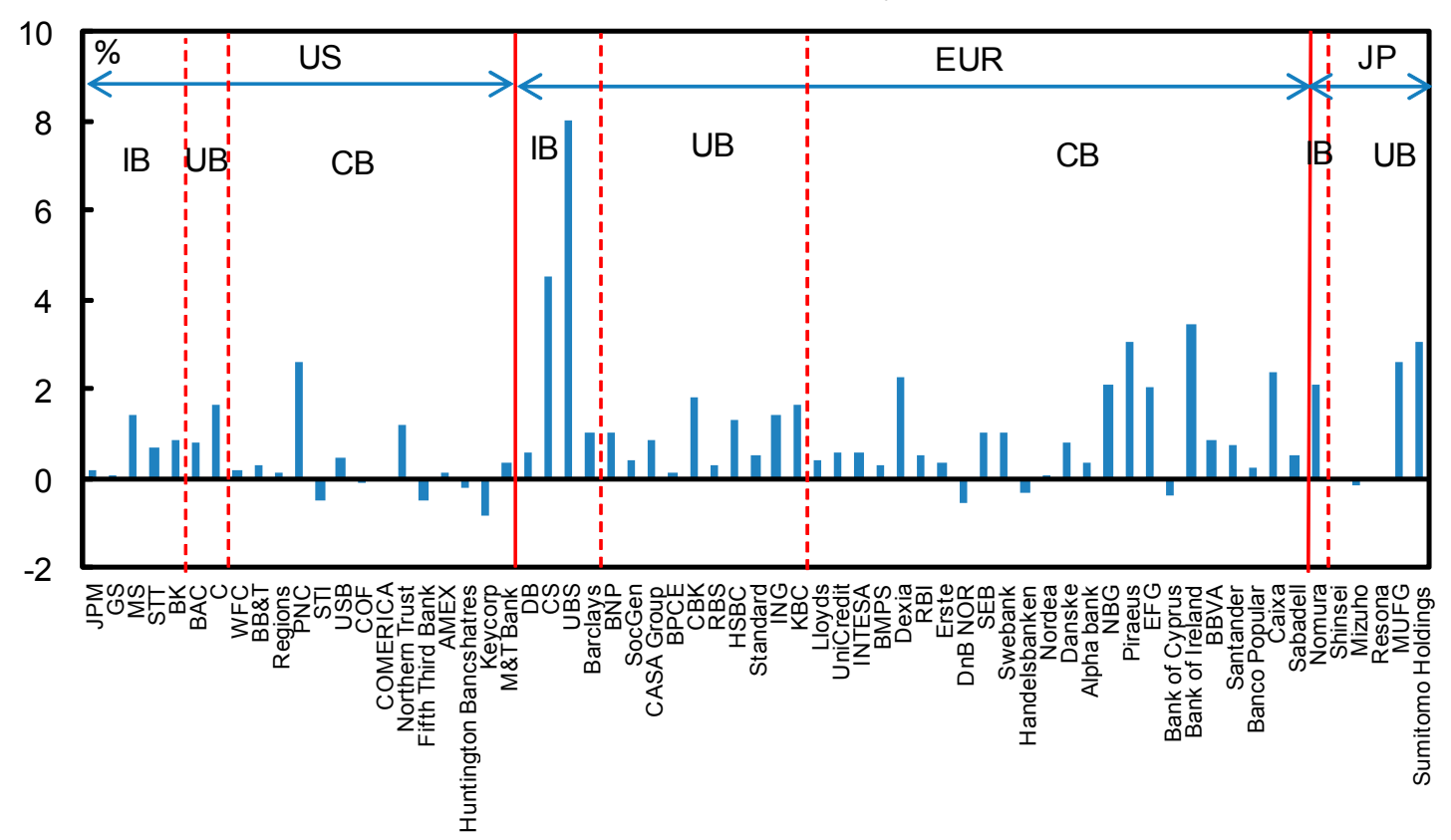

Source: Company reports. 
Table 5. Planned Mitigating Actions by U.S., European, and Japanese Banks, End-2010

\begin{tabular}{|c|c|c|c|c|}
\hline Country/Bank & $\begin{array}{l}\text { Run- } \\
\text { offs }\end{array}$ & $\begin{array}{c}\text { Asset } \\
\text { Disposals }\end{array}$ & Impairments & Other \\
\hline \multicolumn{5}{|l|}{ Europe } \\
\hline $\mathrm{RBI}$ & $\sqrt{ }$ & & & \\
\hline $\mathrm{KBC}$ & $\sqrt{ }$ & $\sqrt{ }$ & & \\
\hline Dexia & & $\sqrt{ }$ & & \\
\hline Credit Agricole & $\sqrt{ }$ & $\sqrt{ }$ & & $\sqrt{ }$ \\
\hline BNP & & $\sqrt{ }$ & & $\sqrt{ }$ \\
\hline Société Générale & $\sqrt{ }$ & $\sqrt{ }$ & & $\sqrt{ }$ \\
\hline BPCE & & $\sqrt{ }$ & & $\sqrt{ }$ \\
\hline Deutsche Bank & $\sqrt{ }$ & $\sqrt{ }$ & & $\sqrt{ }$ \\
\hline Commerzbank & $\sqrt{ }$ & $\sqrt{ }$ & $\sqrt{ }$ & $\sqrt{ }$ \\
\hline Alpha Bank & & $\sqrt{ }$ & & \\
\hline NBG & & $\sqrt{ }$ & & $\sqrt{ }$ \\
\hline Eurobank & & & & $\sqrt{ }$ \\
\hline Bank of Ireland & $\sqrt{ }$ & $\sqrt{ }$ & & \\
\hline UniCredit & & & & $\sqrt{ }$ \\
\hline Intesa & & $\sqrt{ }$ & & $\sqrt{ }$ \\
\hline BMPS & & & & $\sqrt{ }$ \\
\hline ING & & & & \\
\hline Nordea & & & & $\sqrt{ }$ \\
\hline Banco Popular & & & & $\sqrt{ }$ \\
\hline BBVA & & & & $\sqrt{ }$ \\
\hline Santander & & & & \\
\hline Swedbank & & & & $\sqrt{ }$ \\
\hline Credit Suisse & $\sqrt{ }$ & $\sqrt{ }$ & & $\sqrt{ }$ \\
\hline UBS & & $\sqrt{ }$ & & $\sqrt{ }$ \\
\hline Lloyds Group & $\sqrt{ }$ & & & \\
\hline HSBC & $\sqrt{ }$ & & & $\sqrt{ }$ \\
\hline RBS & $\sqrt{ }$ & $\sqrt{ }$ & $\sqrt{ }$ & \\
\hline Barclays & $\sqrt{ }$ & & & $\sqrt{ }$ \\
\hline \multicolumn{5}{|l|}{ Japanese } \\
\hline Shinsei & $\sqrt{ }$ & $\sqrt{ }$ & & $\sqrt{ }$ \\
\hline \multicolumn{5}{|l|}{ United States } \\
\hline Morgan Stanley & $\sqrt{ }$ & & & $\sqrt{ }$ \\
\hline PNC & $\sqrt{ }$ & & & \\
\hline Bank of New York & $\sqrt{ }$ & & & \\
\hline Goldman Sachs & $\sqrt{ }$ & & & \\
\hline Bank of America & $\sqrt{ }$ & $\sqrt{ }$ & & $\sqrt{ }$ \\
\hline
\end{tabular}

Source: Company reports. 
The new Basel capital rules also have diverse effects on different types of bank business models. Table 17 in the Appendix I classifies European, Japanese, and U.S. banks into investment, universal, and commercial banks based on quantitative criteria and qualitative judgment as in Otker-Robe, I. and Pazarbasioglu, C. (2010). ${ }^{25}$ Both Table 6 and Figure 1 show that, even though investment banks have the largest initial core Tier 1 capital ratios, they are the most affected by the new Basel III capital rules, with 6 percent and 6.7 percent pro-forma Basel III common equity Tier 1 capital ratios before and after mitigation, respectively, on average. Both increases in the RWAs and capital deductions will affect investment banks more than universal banks on average. Commercial banks would be the least affected by Basel III on average.

\section{Table 6. Pro-forma Basel III Common Equity Tier 1 Capital Ratios by Bank Business Model, End-2010}

(In percent)

\begin{tabular}{l|rrr}
\hline & IB 2/ & UB & CB \\
\hline Initial Basel I/II common equity Tier 1 capital ratio 1/ & 11.0 & 9.4 & 9.2 \\
RWA increase arising from Basel II.5 and III 1/ & -3.9 & -1.7 & -0.7 \\
Pro forma Basel III common equity Tier 1 capital ratio after RWA increase 1/ & 7.1 & 7.7 & 8.6 \\
Deductions arising from Basel III 1/ & -1.2 & -1.1 & -0.6 \\
Pro forma Basel III common equity Tier 1 capital ratio after RWA increase and capital & & & \\
deductions (without mitigation) 1/ & 6.0 & 6.7 & 7.9 \\
Mitigation 1/ & 0.8 & 0.7 & 0.3 \\
Pro forma Basel III common equity Tier 1 capital ratio after RWA increase, mitigation, and capital dd & 6.7 & 7.3 & 8.3 \\
Memorandum items & & & \\
Number of banks & 10 & 17 & 38 \\
Total assets (in US\$ billion) 3/ & 12,086 & 25,592 & 13,844 \\
\hline $\begin{array}{l}\text { Source: Staff calculations, Da Silva et al. (2011), Nozaki and Saito (2011), TCH (2011a) and company reports. } \\
\text { 1/ Average across the sample of banks. }\end{array}$ & & \\
2/ Also includes U.S. trust banks. & &
\end{tabular}

\section{The effects of increases in RWAs arising from Basel 2.5 and III are larger for} European, Japanese, and U.S. banks with lower average risk weightings. Figure 2, panels $\mathrm{A}$ and $\mathrm{B}$, shows a negative non-linear relationship between average risk weighting and the effects of increases in RWAs arising from Basel 2.5 and III on common equity Tier 1 capital ratios in European and U.S. banks on a pro-forma basis. Both panels A and B seem to suggest that there could be a convergence of risk weighted assets across European and U.S.

\footnotetext{
${ }^{25}$ The quantitative categorization of banks is based on the proportion of securities in the banks' total assets: banks are classified as investment banks if loans are less than 15 percent of total assets or securities are more than 60 percent of total assets, and as commercial banks if loans are more than 60 percent of total assets or securities are less than 15 percent of total assets. After these criteria are applied, all other banks are classified based on judgment, taking into account the scope of derivatives activities, the relative shares of securities and loans, and the share of trading income in total revenue. The final categorization is cross-checked against categorizations used by private sector analysts.
} 
banks. However, as previously suggested in Table 4, the difference in average risk weighting between European and U.S. banks still seems to remain large under Basel III. In addition, Figure 2, panel C, also shows the effects of increases in RWAs arising from Basel 2.5 and III on common equity Tier 1 capital ratios for the few European and Japanese banks that disclose separate information on them. ${ }^{26}$ For commercial and universal banks, Basel III effects on RWAs and common equity Tier 1 capital ratios are larger than Basel 2.5 on average. However, for investment banks, the effects of Basel 2.5 and III on the common equity Tier 1 capital ratios are similar.

${ }^{26}$ EBA (2012) also reports lower effects of Basel 2.5 on RWAs than Basel III in European banks. 
Figure 2. Effect of Basel 2.5 and III on Common Equity Tier Capital Ratios, End-2010 (In percent)

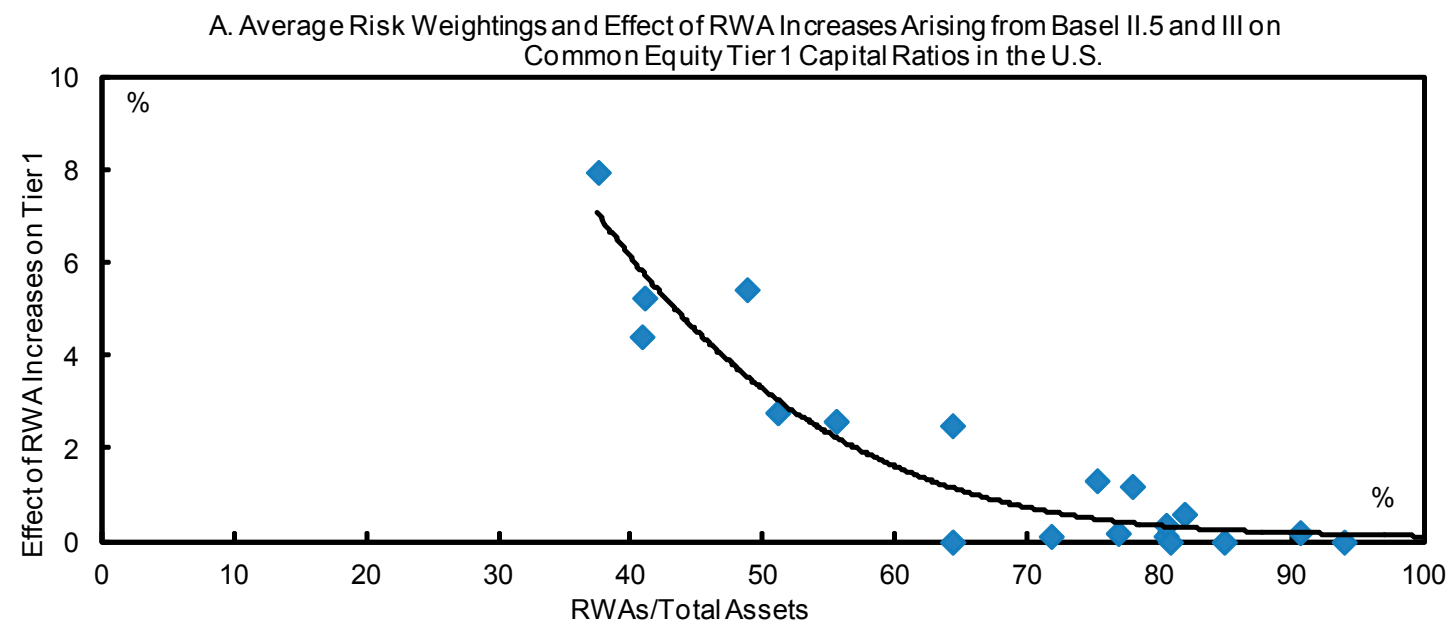

B. Average Risk Weightings and Effect of RWA Increases Arising from Basel II.5 and III on

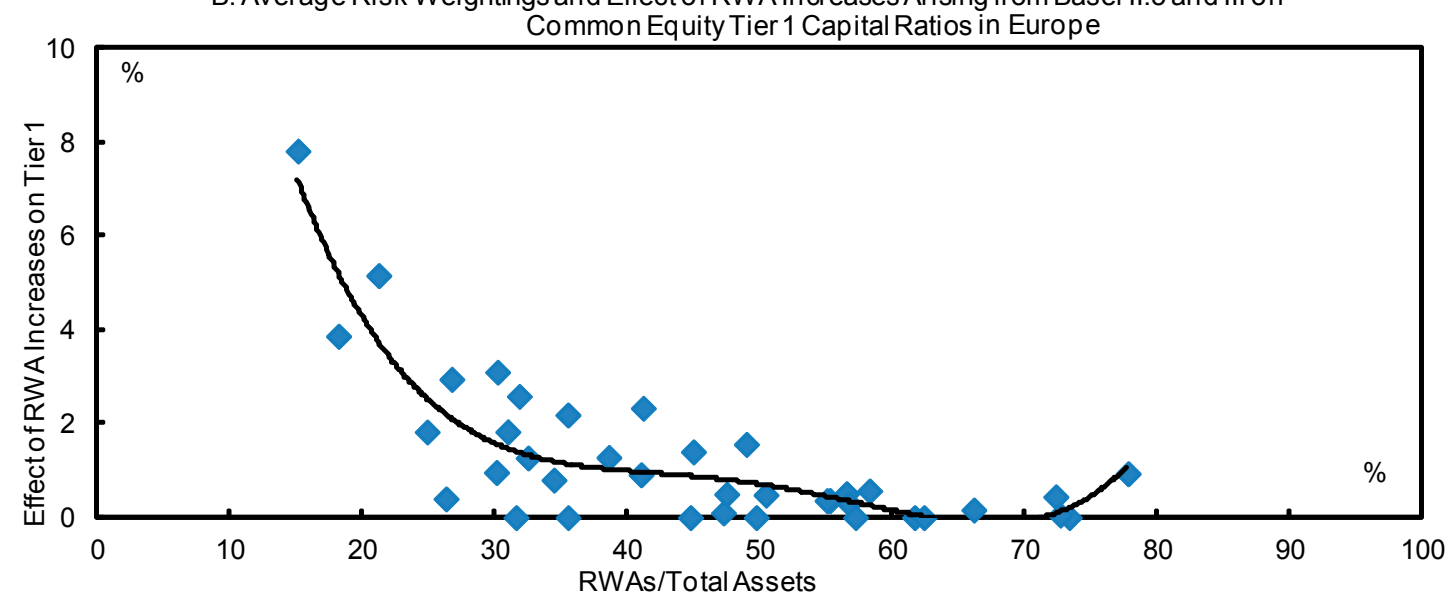

C. Effect of Basel 2.5 and III Increases on Common Equity Tier 1 Capital Ratios

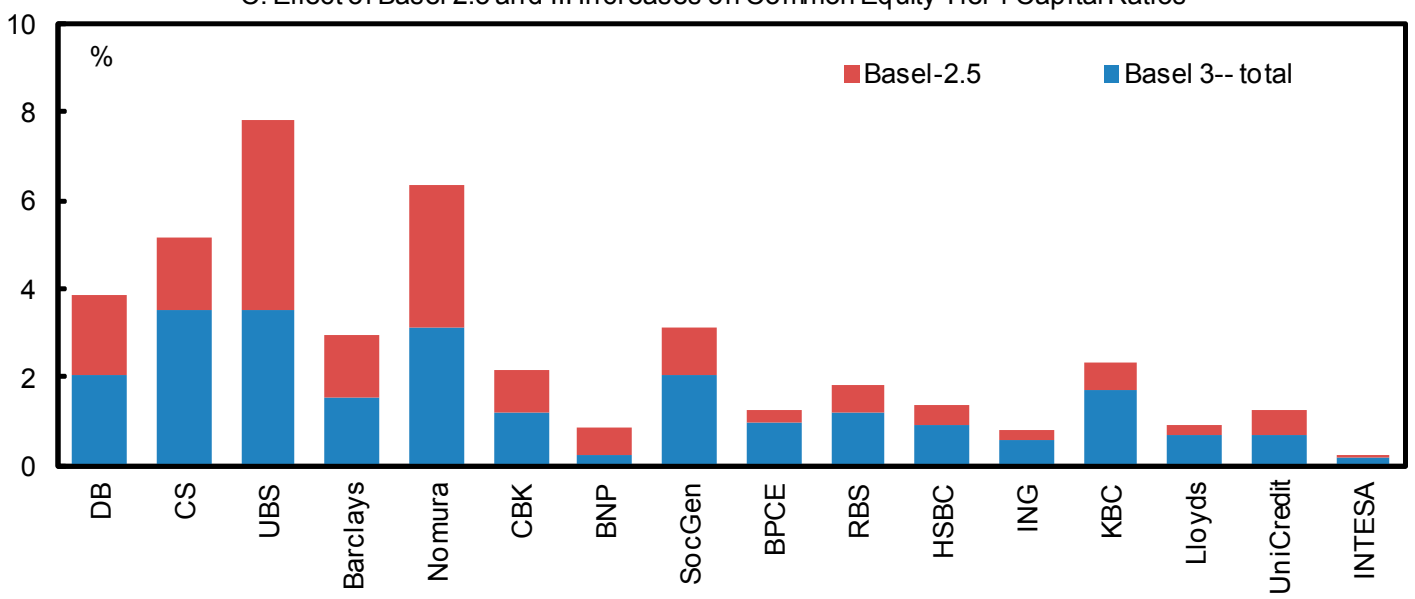

Source: Company reports 


\section{Effects of Changes to Capital Levels on Lending rates}

The impact of higher capital on lending rates does not seem large in economic terms. Table 7 shows the net stand-alone impact from changes in expected capital levels in the three regions on the required interest rate produced by the loan pricing formula. It is less than the 25 bps that generally represents the smallest increment in which major central banks adjust their short-term policy rates, and is comparable to the $11 \mathrm{bps}$ increase in lending rates in U.K. banks found in Miles, Yang, and Marcheggiano (2010) after allowing for the 45 percent offsetting effect arising from the Modigliani-Miller proposition holding partially. ${ }^{27,28}$ In addition, the gross stand-alone effect of higher capital on lending rates in Europe and the United States is also similar to the 20 bps and 36 bps increase in lending rates for U.K. and U.S. banks found in Miles, Yang, and Marcheggiano (2010) and Gorton, Lewellen, and Metrick (2011), respectively.

\section{However, the effect is significant compared to pre-tax returns on assets for the banking industry. Pre-tax return on assets (ROA) in banking is generally in the range of $100 \mathrm{bps}$ or less. Thus, the need to pass along even 20 bps to some combination of customers, employees, and investors can loom large in comparison with existing profit margins. This is one reason why banks are likely to take mitigating actions, including expense cuts, as explained below.}

\section{A target minimum ratio of 10 percent common equity Tier 1 capital to risk-weighted assets is assumed. This represents a buffer of 3 percentage points above the Basel III minimum of 7 percent ( 4.5 percent plus a 2.5 percent conservation buffer.) The additional 3 percent reflects both mandatory additional capital to be required for Systemically Important Financial Institutions (SIFIs) and a further discretionary buffer. The SIFI capital surcharge will initially range from 0.5 percentage points to 2.5 points, with room for regulators to increase this to 3.0 points for SIFIs already at the 2.5 point level who take on undue additional risk. These SIFI surcharges are likely to add 1.0 to 1.5 points to the required capital levels of the banking system as a whole. The rest of the 3 points assumed here reflects the fact that managements virtually always choose to operate with some buffer to minimize the probability of regulatory intervention and will wish to avoid eating into the conservation buffer, thereby incurring mandatory limitations.}

\footnotetext{
${ }^{27}$ The comparison to the 25 bps that generally represents the smallest increment in which major central banks adjust policy rates, is an approximation. For example, central bank moves usually only directly affect short-term rates, whereas loans have an average duration of several years. In addition, long-term rates could react to the tightening of short-term rates in different ways. They could move by the same amount of short-term rates in a parallel shift of the yield curve; they could move less than short-term rates with an inversion of the yield curve; or, finally, they could move more than short-term rates with a steepening of the yield curve.

${ }^{28}$ The changes in lending rates in the United Kingdom and the United States in Miles, Yang, and Marcheggiano (2010) and Gorton, Lewellen, and Metrick (2011) are adjusted for a change in the capital-to-total assets ratio of 1.24 percent and 2.65 percent, respectively.
} 
Another important assumption is that investors would require a 12 percent return on
equity (ROE) for all regions, prior to any effects of regulatory changes. This is below the 15 percent ROE figure that some in the industry have said is the minimum investors will accept. In practice, BCBS (2010) found that banks had returned an average of 14.8 percent over the preceding 15 year period. Since investors generally paid well above book value for bank stocks during that period, they must have been willing to accept a significantly lower return on their own equity investment, unless they fooled themselves over a very prolonged period. ${ }^{29,30}$ For its part, the IIF, despite its ties to the financial industry, assumes significantly lower ROE requirements than the 12 percent chosen for this study: using a 10 percent ROE for the United States, 7.5 percent for the Euro Area and Switzerland, 9 percent for the United Kingdom, and 5 percent for Japan. ${ }^{31}$ The 12 percent ROE for the United States and Europe is chosen in this study as a conservative figure that falls between the oft-stated 15 percent requirement and the presumably more realistic required returns shown by historical measures and the IIF's prospective estimates. The 7 percent figure for Japan follows similar logic.

Table 7. Effects of Higher Capital Levels on Lending Rates (In percent)

\begin{tabular}{|c|c|c|c|}
\hline & Europe & Japan & U.S. \\
\hline End-2010 pro forma Basel III common equity Tier 1 capital ratio & 7.12 & 6.57 & 6.69 \\
\hline Capital-to-total assets ratio, without risk weighting & 3.06 & 2.95 & 5.36 \\
\hline Assumed minimum capital-to-RWA ratio in equilibrium & 10.00 & 10.00 & 10.00 \\
\hline Implied capital -to-total assets ratio, without risk weighting & 4.30 & 4.49 & 8.01 \\
\hline Necessary increase in capital-to-total assets ratio & 1.24 & 1.54 & 2.65 \\
\hline Assumed base case return on equity required by market & 12.00 & 7.00 & 12.00 \\
\hline Assumed base case cost of other funding sources & 2.00 & 1.25 & 2.00 \\
\hline After-tax unit cost of switching to capital as funding source & 10.60 & 6.13 & 10.60 \\
\hline Stand-alone effect of higher capital on pre-tax loan interest rate & 0.19 & 0.13 & 0.40 \\
\hline Assumed offset from reduction in return required by market 1 / & -0.09 & -0.07 & -0.20 \\
\hline Net stand-alone effect on pre-tax loan interest rate & 0.09 & 0.07 & 0.20 \\
\hline \multicolumn{4}{|l|}{ Memorandum items } \\
\hline Total assets (in US\$ billion) & 33,961 & 6,038 & 11,522 \\
\hline Total RWA after Basel II.5 and III (in US\$ billion) & 14,597 & 2,713 & 9,233 \\
\hline Tax rate (in percent) & 30.00 & 30.00 & 30.00 \\
\hline
\end{tabular}

\footnotetext{
${ }^{29} \mathrm{n}$ investor's required expected return can be estimated by dividing the expected ROE of a bank by the multiple of book value paid by the investor. Thus, investors who paid twice book value for shares in a firm with a 20 percent expected ROE were implicitly willing to accept a 10 percent return on their own investment.

${ }^{30}$ Haldane, Brennan, and Madouros (2010) point out that the high 20 percent ROE in international banks before the financial crisis was the result of increased leverage (on and off-balance sheet, increased share of assets held at fair value, and writing deep out-of-the money options.

${ }^{31}$ See IIF (2011).
} 
Several assumptions, explained further in an appendix, have a substantial effect on these calculations. Most basically, as explained above, the figures assume that financial markets and bank managements would cause banks to move to at least end-2010 capital levels as a result of the lessons learned from the financial crisis, regardless of regulatory changes. The changes in capital levels would be higher, and the costs increased, if a lower base case capital level were assumed. Equally importantly, it matters how much credit equity investors are likely to give in the long run to the reduced volatility and risk in a banking system with higher capital. Assuming there is no such credit would double the net effects shown above, while assuming a 75 percent pass-through to equity markets would halve the net effects.

Using different assumptions for the cost of capital or other funding sources would not have a major effect on the figures. For example, as shown in Table 15 below, the net effect of capital increases in the United States only changes by 2 bps for each additional point in required return on equity. Raising the assumed cost of other funding in the United States would lower the cost of moving to higher capital levels by $1 \mathrm{bps}$ for each percentage point increase in funding costs.

\section{A comparison of Europe versus the United States}

It may be counterintuitive that the capital requirements would have a greater effect on lending rates in the United States than in Europe, given the prevalent belief that U.S. banks are better-capitalized at the moment. ${ }^{32}$ This finding does not indicate that the total economic impact would be less in Europe, given the much higher proportion of credit provided by banks in Europe compared to the United States. In fact, the projected annual increase in total credit costs in Europe, based on the above figures, would be about US\$30 billion a year ( 9 bps times US\$34 trillion in total banking assets as of 2010) compared to about US\$23 billion in the United States (20 bps times US\$11.5 trillion.) This is a crude estimate, since there will also be effects on non-bank lending spreads, but such changes in lending rates are likely to be significantly smaller than for banks.

The estimated long-term minimum capital levels are driven by the ratio of capital to risk-weighted assets, on which the three regions are very broadly equal. This contrasts with the ratio of capital to total assets, which appears to be the main focus of financial market fears, where Europe and Japan are at about 3 percent, with the United States at over 5 percent. This latter ratio is roughly the same as the Basel III leverage ratio, which appears

\footnotetext{
${ }^{32}$ Using a DSGE model Roger and Vleck (2011) reported higher long-run lending spreads for U.S. banks (20 percent) than for European banks in all scenarios, which include a lower payout ratio in conjunction with a lower ROE. full pass-through with no other action, and a reduction in RWAs associated with an overall cut in lending and a focused cut in lending concentrated in high risk borrowers.
} 
likely to be the binding constraint only for a relatively small portion of the industry, in the long run.

The differential cost of meeting the higher target for capital to risk-weighted assets results from very different average risk weightings across the regions. Since European banks have an average risk weighting of about half the level the United States runs (roughly 40 percent versus 80 percent), they need to raise only half as much capital per dollar of total assets in order to meet any given increase in the ratio of capital to RWAs. An explanation of the complex topic of average risk weightings lies outside the scope of this study, but appears to reflect at least three principal factors. ${ }^{33}$ European banks have a different business model from U.S. banks, with larger balance sheets of lower-risk assets. Accounting differences between International Accounting Standards and U.S. Generally Accepted Accounting Principles play a substantial role as well. Finally, European banks appear to have worked harder to optimize their balance sheet on a risk-weighted basis, reflecting both their longer use of Basel II rules and the pressures they are currently under to minimize the need for additional capital..$^{34}$

\section{E. Liquidity Requirements}

Prior to the recent financial crisis, regulators around the world generally placed a much lower emphasis on liquidity requirements than on capital requirements. As a result, few countries had a rigorous, formalized set of liquidity requirements, although supervisors paid attention, to varying degrees, to potential liquidity problems at individual institutions for which they were responsible.

The crisis underlined how critical liquidity problems can be in determining the fate of individual institutions and in transmitting problems across banking systems and overall financial markets. As a result, the Basel III accord includes two new liquidity requirements, the Liquidity Coverage Ratio (LCR) and the Net Stable Funding Ratio (NSFR).

\section{Liquidity Coverage Ratio}

The LCR is basically a stylized stress test of an institution's ability to withstand a severe liquidity freeze that lasts 30 days. When liabilities mature, they are assumed to be very difficult to roll over, with the degree of difficulty depending on the category of the liability.

\footnotetext{
${ }^{33}$ See Le Leslié and Avramova (2012).

${ }^{34}$ Samuels et al. (2012) surveyed 130 Asian, European, and U.S. equity investors to collect their views on RWA calculations. They found that most investors mistrust reported RWAs. For investors, the major differences between European banks' risk weightings reflect not only differences in their business mix but also in the Basel II approach (standardized or the IRB approach) used by banks, the way internal model works, and the way that national regulators apply the rules.
} 
Undated liabilities, such as demand deposits, are assumed to be withdrawn to various degrees depending on the type and source of the deposit. Retail deposits are assumed to be somewhat "sticky," meaning that a considerable portion of these deposits remains even in troubled times. Deposits from corporations, on the other hand, are assumed to be withdrawn to a much greater extent. Thus, each category of liability is assigned a percentage roll-over figure representing the portion of that liability that either remains a source of funding during the 30 days or is replaced by funds in the same category.

Similarly, each asset category is assigned a percentage haircut. ${ }^{35}$ This represents the loss that would be incurred if that asset were to be liquidated in the middle of a severe financial crisis. Safe, short-term assets have no haircut or a relatively small one while riskier or longerterm assets have higher haircuts or even a full haircut if there is essentially no way to monetize an asset in the 30-day crisis period.

The LCR is the ratio of total assets, after the liquidity haircuts, to the total cash outflows under the stress assumptions. Upon full implementation, the ratio will be required to exceed 100 percent, meaning that the assets, after haircuts, can provide more than enough funds to cover the cash outflows. Supervisors started monitoring the LCR in 2011, but the ratio will only be required as a minimum standard starting in 2015 . However, there has been a great deal of objection by many in the financial industry and other observers and the Basel Committee has indicated the likelihood of further refinements in the formulas prior to the start of the mandatory period. Data gathered during the observation period may also lead to further rule changes.

\section{Net Stable Funding Ratio}

The NSFR is intended to cover risks that stem from excessive maturity mismatches between assets and liabilities. This ratio relates the total amount of assets to the total amount of liabilities maturing in more than one year. The one-year cut-off is somewhat arbitrary, but corresponds to a common market and regulatory convention of treating shortterm instruments as those of less than a year. The NSFR ratio requires that illiquid assets and a small portion of off-balance sheet commitments and contingencies be matched with stable funding sources. Asset and liabilities are then weighed according to their liquidity and stability characteristics, respectively.

\section{The NSFR is intended to counter an economic externality that exists in regard to liquidity crises. Individual financial institutions can potentially be better off as a result of}

\footnotetext{
35 "Haircut" is a term frequently used in the financial markets to represent the extent to which an asset is treated as if it were worth less than its full value. For example, collateralized borrowing usually is for less than the current value of the underlying asset, with a haircut applied to protect the lender from market movements that might occur before they could liquidate their collateral, in the event the borrower does not repay.
} 
holding lower levels of liquidity, unless institutions across the system make the same choice. In the latter case, a liquidity scare can create major losses across the system as fire sales spread across key asset categories, as occurred in 2008-9, forcing central bank intervention. Similar to the LCR, supervisors also started to monitor the NSFR in 2011, but the ratio will become a binding requirement only in 2017. The NSFR has received even more strenuous objections than the LCR and there is a strong expectation that the NSFR will be modified prior to its implementation.

\section{Meeting the Liquidity Requirements}

\section{Banks that would not meet the 100 percent ratio requirements for the two tests could take any of several types of actions or combinations of these actions:}

- Increase the length of liabilities. Liabilities with maturities of over 30 days for the LCR or one year for the NSFR generally are not included in the ratios and, therefore, do not need to be matched by appropriate assets.

- $\quad$ Raise capital. Common equity and other instruments that count as capital, are either perpetual or have very long maturities. Replacing shorter-term liabilities with capital would also reduce the denominator of the LCR ratio and increase the numerator of the NSFR ratio.

- $\quad$ Shorten the maturity of assets. In general, shorter maturity assets have lower haircuts, with lower weights in the denominator of the NSFR ratio and higher weights in numerator of the LCR ratio.

- $\quad$ Switch to higher quality assets. In general, assets of higher quality have lower haircuts, with lower weights in the denominator of the NSFR ratio and higher weights in the numerator of the LCR ratio.

- Shrink, in combination with other actions. Shrinking does not automatically change the liquidity ratios, if everything else stays in the same proportions. However, reducing assets and corresponding short-term liabilities will sometimes be the most cost-effective way to rebalance.

\section{Implications of Adjustment Actions}

Under normal circumstances, each of the potential adjustment actions by banks would reduce profits. When there is a normal upward-sloping yield curve, longer-term liabilities will cost more than shorter-term ones and shorter-term assets will earn less than those of longer term. Capital, for its part, is more expensive than other funding sources. Similarly, higher-quality assets virtually always yield less than lower-quality ones, since risk aversion by investors means that riskier assets must generally pay higher returns. Finally, shrinking a bank's book usually means reducing otherwise profitable business. 
There are also questions about the larger effects on markets and the economy. Maturity transformation is not just an activity from which banks derive profits; it also plays an important economic role. Many savers place a high value on having near-instant access to a portion of their funds, yet the vast bulk of useful economic projects have lives that are too long to be safely funded on this basis. Banks bridge this gap by taking advantage of the fact that savings deposits are "sticky," meaning that they tend to stay in place for long periods, on average, even though they could theoretically be withdrawn on any given day. Liquidity arrangements with central banks, combined with deposit insurance to avoid panic by savers, have been constructed to avoid the biggest risks to having banks rely on this stickiness of deposits.

\section{The Basel III liquidity requirements would almost certainly reduce maturity} transformation to some extent. Indeed, they are intended for that exact purpose, at least as regards banks. Further, it seems likely that regulators would extend similar types of requirements to other institutions if the maturity transformation activity were to migrate to a great extent away from banks. Therefore, it would be useful to have at least a rough estimate of the economic benefits of maturity transformation and of the likely change in those benefits as a result of the liquidity requirements. In particular, there is a concern that European financial markets may not be able to easily accommodate the shifts necessitated by the liquidity requirements (see Barclays Capital (2010d), for example). The analysis here does not attempt to answer these questions, given their complexity and a paucity of theory and data adequate to analyze them.

There may be an additional effect from the reduction in the attractiveness for banks of owning debt in other banks. The new liquidity rules discourage interconnectivity in the financial system, which may force banks to pay up to find buyers of their debt as one of their traditional funding bases, other banks, pulls back. It is difficult to quantify this potential effect, which would, in any event, be offset in its effects on the wider economy by a relatively greater attractiveness of non-bank debt for bank portfolio holdings.

\section{Estimating the funding and liquid assets needed to comply with a 100 percent NSFR and LCR, respectively, is particularly difficult. There is a fairly wide range of uncertainty around the estimates shown in Table 8 below. First, unlike with Basel III capital requirements, few banks have provided any detailed information about their liquidity needs under the new rules. Nor has there been a history of reporting such figures even under older rules, analogous to the situation with capital under Basel II. Therefore, the estimates of the gaps have considerable uncertainty. Second, there is a paucity of information about the costs of potential actions to close those gaps, since there is no detailed data to evaluate the options. Third, the NSFR, and, to a lesser extent, the LCR rules are certain to change and also to be implemented with some differences across countries. For example, the LCR gap reported by the Clearinghouse Association (TCH) in its analysis of the situation in the United States,}


might be halved if U.S. authorities respond to some issues of concern, reducing that gap. ${ }^{36}$ Despite all these uncertainties, the estimates do provide a useful starting point for understanding the potential magnitude of the liquidity effects.

\section{In the U.S. case, there are no available estimates from official sector sources of the} extent of the gaps under the LCR and NSFR. However, it is possible to make a rough estimate by starting with the figures compiled by the BCBS (2012) for 103 large banks around the world, which are likely to comprise most of the global banking assets. Given the estimates for European banks in EBA (2012) that include most of the banking system assets, the difference between BCBS and EBA totals should approximate the gaps for the rest of the world. Further subtracting the Japanese estimates from Nozaki and Saito (2011) provides an upper bound for the portion of the gaps associated with the United States, assuming that the rest of the world has no gap. This gives estimates of US\$695 billion for the LCR and US\$622 billion for the NSFR in the United States. In the case of the NSFR, Table 8 uses a significantly higher figure of US\$1 trillion to reflect the fact that some private sector estimates are much higher.

Table 8. Pro-forma Basel III Liquidity Ratios, End-2010

\begin{tabular}{|c|c|c|c|}
\hline & Europe & Japan & U.S. \\
\hline \multicolumn{4}{|l|}{ Liquidity Coverage Ratio } \\
\hline $\begin{array}{l}\text { Da Silva et al. (2011), Nozaki and Saito (2011), and adjusted BCBS (2012), } \\
\text { respectively (in percent) 1/ }\end{array}$ & 76 & 121 & N.A. \\
\hline Additional liquid assets needed for a 100\% LCR (in US\$ billion) $2 /$ & 1,326 & 53 & 700 \\
\hline \multicolumn{4}{|l|}{ Net Stable Funding Ratio } \\
\hline $\begin{array}{l}\text { Da Silva et al. (2011), Nozaki and Saito (2011), and adjusted BCBS (2012), } \\
\text { respectively (in percent) 1/ }\end{array}$ & 89 & 87 & N.A. \\
\hline Additional long-term funding needed for a 100\% NSFR (in US $\$$ billion) $2 /$ & 1,703 & 554 & 1,000 \\
\hline \multicolumn{4}{|l|}{ Memorandum items } \\
\hline $\begin{array}{l}\text { Da Silva et al. (2011)-Abouhossein (2011) and Nozaki and Saito (2011) number of } \\
\text { banks, respectively }\end{array}$ & 33 & 3 & N.A. \\
\hline $\begin{array}{l}\text { Da Silva et al. (2011)-Abouhossein (2011) and Nozaki and Saito (2011) total } \\
\text { assets, respectively (in US\$ billion) }\end{array}$ & 31,378 & 5,942 & N.A. \\
\hline
\end{tabular}

Figures from EBA (2012) suggest Basel III liquidity ratios may also be modestly smaller than shown in Table 8. EBA banks reported an average LCR of 71 percent and an average

\footnotetext{
${ }^{36}$ In particular, The Clearinghouse Association argues that securities issued or guaranteed by Fannie Mae and Freddie Mac should be fully allowed to count for liquidity purposes, rather than being put in a bucket that is limited to 40 percent of the total liquidity sources. They further argue that borrowing capacity with the Federal Home Loan Banks, another set of government-sponsored enterprises, should be given some credit as well.
} 
NSFR of 89 percent as of end-June 2011, with a shortfall of liquid assets at approximately $€ 1.2$ trillion and of long-term funding at $€ 1.9$ trillion. The difference between Table 8 and EBA figures could also result from the EBA imposing a common definition across banks or from a sample bias in the figures in Da Silva et al (2011). ${ }^{37}$

\section{Effects of Changes to Liquidity Levels on Lending rates}

The total estimated stand-alone cost of the liquidity changes is similar to that produced by the capital changes. Table 9 shows the estimated impact of higher liquidity requirements, using the credit pricing formula. The central assumption is that banks will experience an increase in the average cost of their funds as they lengthen liability maturities or a decrease in their investment returns if they instead shorten the maturity of their assets. ${ }^{38}$ The level of impact is intuitively reasonable, in that the vast majority of a bank's funding is from sources other than capital, so profits are quite sensitive to changes in those costs. The liquidity requirements also represent a much larger change from previous regulation than is true for the capital reforms, since regulators had generally treated liquidity as a lower priority item. The new rules also remain in flux and do not become binding for a number of years, suggesting that the baseline data on banks generally reflect few actions already taken to deal with the liquidity regulations, leaving more of an adjustment still to be done.

Table 9. Estimated Effects of Liquidity Changes on Lending Rates

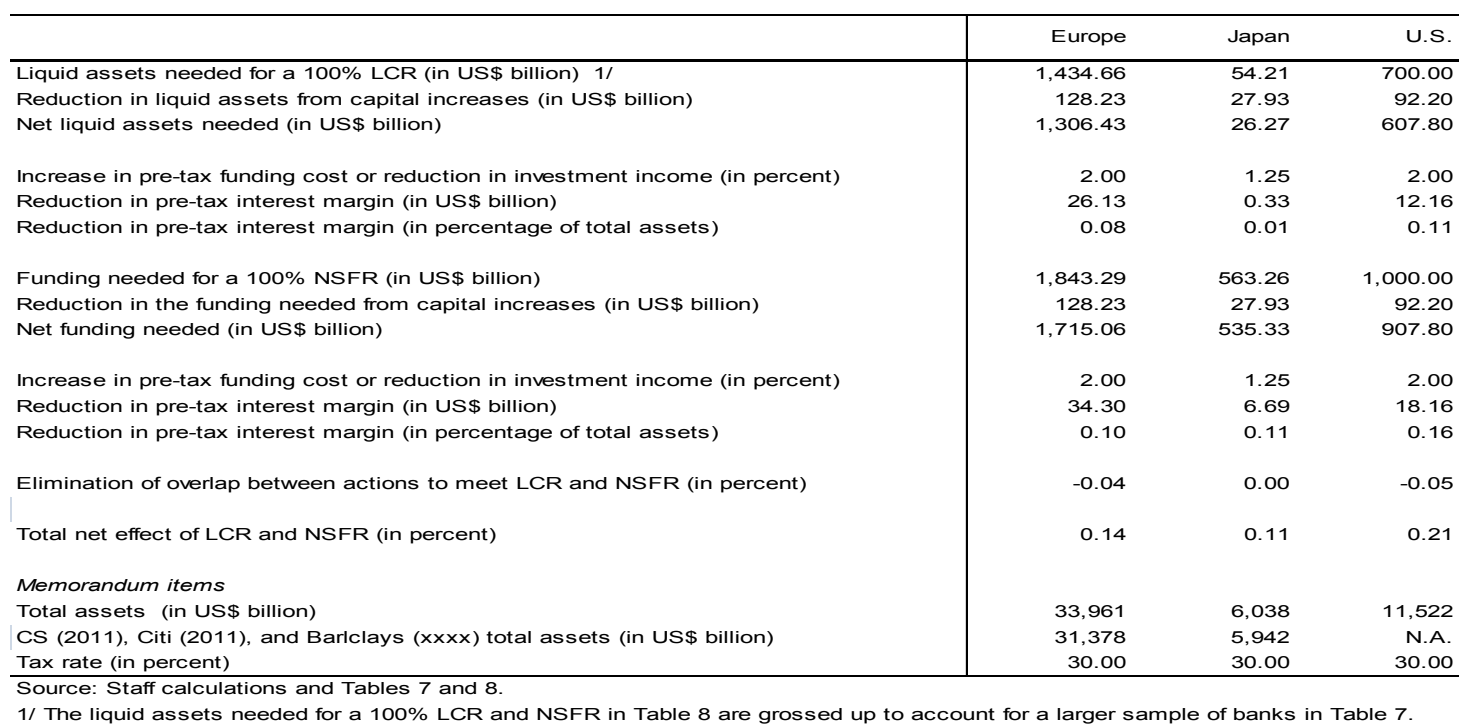

\footnotetext{
${ }^{37}$ BCBS (2012) also reported that the average LCR and NSFR in the sample of 103 global banks are 90 and 94 percent, respectively, as of end-June 2011. The associated shortfall of liquid assets and of long-term funding are $€ 1.76$ trillion and $€ 2.78$ trillion, respectively, as of end-June 2011 .

${ }^{38}$ Abouhossein (2010) illustrates this type of analysis in great detail.
} 
There are three key assumptions influencing the costs. First, the size of the assumed liquidity gap is central to the analysis. There are few good sources for this, limiting any ability to cross check. Public reports do not give sufficient detail on asset and liability structures to independently calculate the gaps with any certainty. Second, the cost of altering the maturity of the assets or liabilities can only roughly be estimated. The figures used above are broadly consistent with those of the equity analysts who have reported on this, but are significantly higher than the 100 bps assumed by the BIS based on historical averages for interest rates. ${ }^{39,40}$ It would be helpful to have more precise and accurate figures, but this is not feasible without a much more detailed study. Third, it is impossible to estimate with any precision the overlap between the actions taken to meet the LCR needs and those to meet the NSFR requirements. It is assumed that half the cost of the smaller of the two changes would be eliminated through that overlap.

The costs of liquidity adjustments are assumed to be spread evenly across the loan book and other asset categories. For lack of more detailed information, each dollar of loan is assumed to bear the same impact as a dollar of investment or other assets. This may overstate the effect on the loan book, since the liquidity requirements appear likely to hit investment banking activities harder.

\section{F. Derivatives Requirements}

The G-20 has committed to a number of actions to make derivatives safer and more transparent. Standardized derivatives will be pushed towards trading on exchanges (and similar mechanisms that are technically not exchanges) and clearing through central clearinghouses. Customized derivatives trades will carry higher safety margins of capital and collateral. Other technical reforms also increase transparency and safety.

Exchange trading is much more transparent than the current dominant mechanism of bilateral transactions where a client contacts at most a few dealers and compares their prices before transacting with one dealer. Clients will have a clearer idea about market conditions before they commit to a trade and there will be much more information available afterwards to market participants about what trades have taken place.

Central clearing houses are intended to reduce, and better manage, counterparty risk. The clearing house stands between the two counterparties to a derivatives transaction, so that each external party's exposure is to the clearing house and not to each other. This matters because derivatives, unlike many other financial instruments, commit the two sides of a trade to perform in the future, creating credit risk that the other side will fail to do so. Central

\footnotetext{
${ }^{39}$ See Abouhossein (2011), for a particularly detailed analysis.

${ }^{40}$ See BCBS (2010).
} 
clearing houses are intended to be very strong entities that will be safe counterparties, in addition to having the advantage of being able to net across a very wide range of offsetting positions created by the counterparties with which they transact. Clearing houses attempt to ensure their own safety by requiring cash collateral, known as "margin," from counterparties, with the level of the margin fluctuating with the profit or loss in the contracts implied by current market pricing, as well as the degree of volatility in contracts of that type. As a second line of defense, clearing houses also require both up-front and contingent capital from the dealers who are members of the clearing house.

Those derivatives that remain too customized for clearing houses will trigger stronger safety margins. Dealers will have to hold significant amounts of capital against their customized derivatives risks, more than for exchange-traded positions. They will also face a new mandate to require collateral from most counterparties with whom they transact, in order to reduce their risk of losses if the counterparty fails to perform as promised.

\section{Effects on Bank Profits and Lending rates}

The derivatives market has been dominated by very large banks. These firms have been perceived as highly creditworthy, which was important in light of the credit risk created when entering into a derivatives contract, given the reliance on promises of future performance. These leaders have also generally had the necessary sophistication to create and manage derivatives transactions and positions, as well as the extensive customer relationships that can help to generate such transactions.

Large banks will likely be relative losers as a result of derivatives reforms. Customized derivatives, which have been a product with high profit margins, will be replaced to a large extent by standardized derivatives, which will tend to have lower profit margins as a result of the greater competition and transparency. Offsetting this, bank capital requirements will go down as trades shift to exchanges and clearing houses, although the benefits will be partially reduced since the customized derivatives that remain will carry considerably higher capital requirements. Finally, Deloitte (2011) concludes that, even if margins are compressed, larger dealers will benefit to some extent from the derivatives reforms as they earn fees for collateral management and clearing and share revenues with Central Counterparties (CCPs). These gains would partially offset the losses from the direct effects of reform.

There is a debate about the extent to which banks will try to recoup lower derivatives profits by raising prices of other products. The answer depends in part on the extent to which derivatives have been treated as separate profit centers rather than as one part of the total profitability of dealing with a particular client or counterparty. If derivatives were a completely separate profit center, and priced accordingly, then there would be no crosssubsidies with other products. On the other hand, it is clear that, in many instances, derivatives profits were one piece of a larger customer relationship. Sophisticated clients, 
who tend to be the largest users of derivatives, have been aware of the relative level of profitability of the derivatives business they provide and have looked for better pricing on loans or other products to offset high profit margins on derivatives. To the extent that there are cross-subsidies like these, a reduction in derivatives profitability for a bank could lead to increases in the price of other products.

Small and medium-sized banks are likely to benefit from derivatives reforms. First, they will have some new profit opportunities in aiding their clients to access markets that would be more open and less dominated by a small group of large, sophisticated dealers. Second, they may well find better pricing for the derivatives that they purchase for their own needs, for the same reasons that non-financial firms are likely to benefit, as explained below.

Non-financial firms, often called "end users" in this context, should benefit on the whole. Standardization of derivatives should drive transaction costs downwards, as it has for other financial products. Such margin compression should provide a very substantial benefit for end-users, given the importance of derivatives. This would be offset by three factors. One, they may have to begin putting up collateral on customized derivatives positions and will have to meet margin requirements on centrally cleared positions. Two, access to customized derivatives for specialized needs may be reduced or the price may go up significantly. Three, the elimination of cross-subsidies from derivatives profits may raise the price they pay for credit or other financial products.

The new rules will also increase the economy's total needs for liquid assets. This will be occurring at the same time as banks themselves are being pushed towards buying more liquid assets. The combined effect will presumably be to push down the returns on liquid assets, since buyers will have a number of reasons to own them almost without regard to their yields.

For simplicity and conservatism, the analysis here assumes that the cost to the large banks represents the total effect on the economy, potentially overstating the net costs. In reality, it is likely that there are net economic gains for the other participants in the derivatives market, which would reduce the total cost to the economy and perhaps even turn it into a gain. However, it is too difficult to quantify these benefits and it seemed useful to show that even a conservative estimate does not suggest a large net cost.

The primary risk in assuming that the net effects on all participants in the derivatives market other than the major dealers rounds to zero is that the effects of new collateral requirements might turn out to more than offset the other advantages for non-dealers. At first glance, this concern appears plausible, since there are estimates that CCPs may require US\$1 trillion or more of initial margin for the positions that they clear, as a result of massive increases in central clearing, combined with more conservative margin requirements resulting from the lessons of the financial crisis. 
However, a more detailed review suggests that this will not more than offset the benefits for non-dealers, although it is impossible to be sure. Heller and Vause (2012) estimate that the initial margin required by CCPs for all interest rate and credit default swaps might be US $\$ 0.7$ trillion in an intermediate case. They indicate that such swaps account for about twothirds of all swaps by both notional amount and by market value. Grossing the US\$0.7 trillion up to reflect the missing one-third of swaps raises the figure to approximately US\$1.1 trillion. Singh (2010) estimates that collateral at the major dealers already covered about 44 percent of their swap exposures. If this can serve as a reasonable proxy for the level of existing collateralization of the swaps which would be cleared by CCPs, then the net new collateral required as a result of moving to CCPs would be approximately US\$0.6 trillion.

There will be a cost to funding the additional collateral. For dealers, this would likely involve either selling some longer-term securities to replace them with the short-term government notes that CCPs will generally require, using repos of longer-term securities to achieve the same effect, or raising some additional funding to purchase the necessary collateral outright. For non-dealers, the most likely approach will be to borrow funds in order to buy appropriate securities for the collateral needs. For newly raised funds, the net cost will be the difference between the rate on the borrowing and the rate earned on the securities to be used as collateral, since interest on the securities used as collateral remains with the owner of the securities. For a switch from longer-term to shorter-term securities or the use of repos, the cost will be the difference in interest earnings. On average, it appears reasonable to assume that the net cost will be in the range of 200 bps.

Thus, the first-order effect of the higher collateral requirements would be to raise credit costs by approximately US\$12 billion a year (US\$0.6 trillion times 2 percent). Even without the offsets described next, this could be offset by raising lending rates by about 3 ps on the total size of assets held by banks in Europe and the United States. However, even this figure is likely to exaggerate the net effects, since there are a number of offsets:

- $\quad$ Implicit lending rates in bilateral derivatives transactions. The pricing of derivatives by dealers already includes a credit component when a counterparty does not provide collateral up-front. This cost is no less real for being unstated. It will no longer be necessary when dealing with a CCP or will be at a far lower level to reflect the much higher safety of a CCP. Unfortunately, it is impossible to make a good estimate of the total implicit lending rates built into existing bilateral deals.

- $\quad$ Lower capital requirements. Dealers will have lower capital requirements, and therefore lower costs, when clearing through a CCP rather than bilaterally.

- $\quad$ Lower margins on exchange-traded products. There is a strong consensus that dealers will have lower margins on exchange-traded transactions than on their existing bilateral derivatives deals. This cost is built into the estimates in this paper for the cost to dealers, but would be exactly offset by reduced costs for non-dealers. 
In sum, it appears reasonable to assume, as this paper does, that the various effects will at least net out for everyone but the major derivatives dealers, although it is impossible to establish this with certainty. More positively, it is also quite probable there would be a net benefit to the economy rather than the cost conservatively assumed here. It should also be emphasized that this paper looks at the cost in non-crisis years, without taking account of the benefits of a reduction in the frequency of financial crises and the damage they cause. So, even if there is indeed a "cost" as shown here in the non-crisis years, this does not imply that the derivatives reforms do more harm than good.

\section{Estimates of the costs of derivatives reforms on European and U.S. banks contain a} high degree of uncertainty. ${ }^{41}$ Even though the large dealers will be the most affected, the wide range of estimates in Table 10 is an indication that, without further clarity from the final rules, the effects of the derivatives reforms on banks cannot be pinned down easily. In addition, banks will need to post initial margins and default funds for any CCPs in which they will clear their derivatives transactions. The levels for these have yet to be determined and, therefore, their costs cannot be estimated. However, given the magnitudes in Table 10, it appears that the costs to the economy as a whole of derivatives reforms may not be substantial.

Table 10. Effects of Derivatives Reforms on Banks per Year (In US\$ million)

\begin{tabular}{|c|c|c|}
\hline & Europe & U.S. \\
\hline \multicolumn{3}{|l|}{ Da Silva, Goel, and O'Donohoe (2010) } \\
\hline No. of banks & 14 & 4 \\
\hline Derivative Reform Gross Loss & 4,738 & 3,766 \\
\hline Derivative Reform Net Loss after Cost Reduction & 2,843 & 2,260 \\
\hline \multicolumn{3}{|l|}{ Goldberg, Blyakher, Keating, and Nash (2010) } \\
\hline No. of banks & $\ldots$ & 25 \\
\hline Derivative Reform Gross Loss & $\ldots$ & 2,651 \\
\hline Derivative Reform Net Loss after Cost Reduction & $\ldots$ & $\ldots$ \\
\hline \multicolumn{3}{|l|}{ Horowitz, Foundos, Ketron, and Fandetti (2010) } \\
\hline No. of banks & $\ldots$ & 4 \\
\hline Derivative Reform Gross Loss & $\ldots$ & 6,911 \\
\hline Derivative Reform Net Loss after Cost Reduction & $\ldots$ & 1,235 \\
\hline \multicolumn{3}{|l|}{ Moszkowski, Goldschneider, and Chubak (2010) } \\
\hline No. of banks & $\ldots$ & 4 \\
\hline Derivative Reform Gross Loss & $\ldots$ & 3,428 \\
\hline Derivative Reform Net Loss after Cost Reduction & $\ldots$ & \\
\hline
\end{tabular}

The effects of derivatives reforms on bank credit pricing appear to be quite low. This is despite an approach of assuming that the losses by big banks will not be offset by economic gains to other market participants. The estimates used here are from early in the reform process and are fairly crude. Nonetheless, the very low size of the impact suggests that more

\footnotetext{
${ }^{41}$ While Japanese banks might be affected by the derivatives reforms, cost estimates are not available for them.
} 
refined numbers are unlikely to produce figures that rise to the importance of the capital or liquidity reforms.

Table 11. Estimated Effects of Derivatives Changes on Lending Rates

\begin{tabular}{l|rrr}
\hline & Europe & Japan & U.S. \\
\hline Total estimated effect on net income (in US\$ billion) & 2.84 & N.A. & 2.26 \\
Effect on pre-tax income (in US\$ billion) & 4.06 & N.A. & 3.23 \\
Cost per dollar of assets (in percent) & 0.01 & N.A. & 0.03 \\
& & & \\
Memorandum itens & & & \\
Total assets (in US\$ billion) & 33,961 & 6,038 & 11,522 \\
Tax rate (in percent) & 30.00 & 30.00 & 30.00 \\
\hline Source: Staff calculations and Tables 7 and 10.
\end{tabular}

\section{G. Securitization Requirements}

The Dodd-Frank Act and pending European legislation will have significant effects on how securitizations are created and sold. Broadly similar steps are being taken on the two sides of the Atlantic. ${ }^{42}$ Securitizers will be required, in many cases, to keep a piece of the risk, in order to better align their interests with those of the purchasers. Disclosure requirements and underwriting standards are heightened, to increase the quality of offerings and of the information needed to buy them sensibly. There are also a number of indirect effects resulting from other reforms, such as the pressures on rating agencies to do a more careful job of rating securitizations, due to heightened oversight in Europe and higher legal standards of liability in the United States. Capital requirements for securitized assets owned by banks may also be increased, sometimes significantly, from Basel II levels.

"Skin in the game" requirements will raise the cost for banks of participating in securitizations. Arrangers of securitizations, which are often banks or their affiliates, will be required to hold a piece of many securitizations that they sell. The United States and Europe seem to have both settled on 5 percent as the size of that piece, although that could change in Europe before the legislation is finalized. In the United States, there are exceptions for securitizations of Qualified Residential Mortgages (QRMs) that are mortgages meeting fairly strict underwriting guidelines and for mortgages securitized by Fannie Mae and Freddie Mac, at least as long as they are effectively owned by the federal government. Europe appears likely to have fewer exceptions, although this will not be clear for some time.

The "skin in the game" requirement will add costs. Banks are generally not the most costeffective holders of mortgages, which is why they securitize so many of their own mortgages

\footnotetext{
${ }^{42}$ It is unclear what will eventually happen in Asia, where securitizations have been less common.
} 
in the first place. The additional capital and liquidity requirements created by holding

5 percent of the relevant securitized mortgages will create expenses for them. Risks will also be higher as they move from a fee-oriented business model to one in which they retain more of the risk themselves.

Other reforms may add administrative costs, but could save banks money over time. It is in the interest of the banks for there to be a well-functioning securitization market. In fact, it is likely that a number of the reforms would have evolved as market responses even without regulation, such as some of the measures that increase transparency. Other reforms would perhaps not have evolved without regulation, but may limit future losses by banks related to securitizations that go wrong. It is difficult to quantify many of these impacts, since there exist considerable legal risks in the judicial process and it is unclear how market volumes might respond to various reforms.

\section{It proved impossible to develop satisfactory cost estimates for the securitization} changes, as a result of the many uncertainties and the scarcity of external estimates. It appears likely that the impacts will be roughly of the size of the derivatives reforms, rather than the considerably larger effects from capital and liquidity changes, but it is impossible to be sure of this at this point.

\section{H. Taxes and Fees}

\section{The financial sector will also face higher taxes and fees, as a further response to the} financial crisis. There are four principal categories of revenue raising specifically targeted at the financial sector:

- Increases in deposit insurance and similar premiums. Many countries require banks, and sometimes other financial institutions, to pay insurance premiums to support a fund to protect depositors or other customers of financial institutions. The large losses in the financial crisis have generally caused these premium levels to increase and, in some cases, for new funds to be established. The aggregate premium levels are generally set with the intention of bringing in sufficient revenue to be self-supporting over time. The specifics of the premium structure are often designed to provide incentives to operate on a safer basis, such as by charging a higher premium for riskier institutions.

- $\quad$ Taxes related to bonus payments above certain levels. A number of countries have considered taxing bonuses to financial sector executives that exceed certain levels. The United Kingdom is the only country to follow through, with a one-off bonus tax related to bonuses paid for 2009 performance that was charged to the financial institutions paying the bonuses. There are currently no bonus taxes in operation or near implementation. 
- $\quad$ Taxes tied directly to the financial crisis. The Obama Administration in the United States proposed a Financial Crisis Recovery Fee (FCRF), essentially a tax designed to recover the taxpayer losses from the Troubled Asset Relief Program (TARP). This does not appear likely to pass through Congress, especially since the expected TARP losses have shrunk to relatively modest levels from much higher original estimates.

- $\quad$ Financial transactions tax. There is a lively debate going on now as to whether there should be a new, broad-based tax on a wide range of financial transactions. There appear to be two principal arguments for such a tax. First, it is potentially a way of garnering a large amount of revenue from the financial sector without placing a very high tax on any particular transaction, given the massive volume of financial transactions around the world. Second, some favor the tax because it could make the financial sector smaller, simpler, and less active. There is a significant subset of financial instruments which rely on the existence of extremely efficient market operations, which would be made less efficient by such a transactions tax. Others oppose such a tax for a wide variety of reasons, including concerns about loss of market efficiency and distortions to capital allocation, skepticism that a sensible system can be designed given the broad range of financial transactions that exist or can be created, and a belief that regulatory arbitrage would be inevitable and harmful. Europe is seriously considering instituting such taxes, despite opposition from the United Kingdom. However, the United States and a number of other non-European countries are strongly opposed. ${ }^{43}$

\section{Effects of New Taxes on Lending rates}

\section{Increases in taxes and fees affect financial activity in the same ways as other cost} increases. Banks may choose to shrink by refusing business that was marginal and no longer meets their profit criteria as a result of higher costs. Other business would be retained, but some or all of the costs would be passed on to customers, employees, or other parties. Responses may be across the board or may differentially affect certain lines of business or balance sheet categories, especially if the taxes or fees are targeted.

Table 12 includes anticipated cost increases of the following amounts, based on national fiscal estimates. Their effects on credit are discussed in detail in the next section since bank responses should be largely the same as to any other increase in costs.

\footnotetext{
${ }^{43}$ See Claessens, Keen, and Pazarbasioglu (2010).
} 
Table 12. Annual Fees and Taxes on European and U.S. Banks

\begin{tabular}{l|cc}
\hline & Europe & U.S. \\
\hline Financial stability contribution & 5.9 & $\ldots$ \\
Deposit insurance fee changes & 8.8 & 2.0 \\
Orderly liquidation fund & $\ldots$ & 0.6 \\
Other fees & $\ldots$ & 0.7 \\
\hline Source: Schorer, Michael et all (2011) and Elmendorf (2011)
\end{tabular}

Taxes and fees that have already been passed, or are probable, do not appear likely to have a very large effect on credit pricing, although not a negligible one either. The methodology here is quite straightforward, simply taking the expected tax costs based on official estimates and dividing them into the total asset base.

\section{Table 13. Estimated Effects of Tax and Fee Changes on Lending Rates}

\begin{tabular}{l|rrr}
\hline & Europe & Japan & U.S. \\
\hline Total estimated effect on net income (in US \$ billion) & 14.70 & 0.00 & 3.38 \\
Effect on pre-tax income (in US\$ billion) & 20.99 & 0.00 & 4.83 \\
Cost per dollar of assets (in percent) & 0.06 & 0.00 & 0.04 \\
& & & \\
Memorandum itens & & & \\
Total assets (in US\$ billion) & 33,961 & 6,038 & 11,522 \\
Tax rate (in percent) & 30.00 & 30.00 & 30.00 \\
\hline Source: Staff calculations and Tables 7 and 12.
\end{tabular}

\section{Integrated Effects on Credit Provision}

The aggregate effects of these areas of financial reform will be different from the sum of the stand-alone impacts. There are numerous ways in which responses to one area of regulation will either reinforce or offset changes in other areas. Banks, and their investors, will also respond in additional ways to the overall effect of the combined regulatory changes beyond those effects that are captured in a stand-alone analysis.

\section{Interactions between Different Regulatory Categories}

Higher capital requirements generally lower the liquidity requirements. None of the financial instruments that count as capital for purposes of Basel III carry with them any liquidity requirements, since they are all of sufficiently long maturity to fall outside the tests. Therefore, forcing banks to hold more capital reduces liquidity requirements, all else equal. The liquidity analysis presented here includes a rough adjustment for this interaction.

Actions to improve liquidity will frequently reduce capital requirements. One of the methods to improve the LCR and NSFR of a bank is to switch into assets that are safer and 
consequently more liquid, therefore bearing a lesser haircut for purposes of the liquidity ratios. In general, these safer assets will also carry lower risk-weightings for capital purposes.

Derivatives rules change capital requirements. Customized derivatives will carry higher capital requirements than they did before, increasing the need for capital. In addition, and probably of more importance over time, there will be a major movement from customized to standardized derivatives, changing capital requirements further. It is not clear at this point what the net effect will be.

Some taxes and fees, and proposed taxes and fees, exclude equity and long-term debt. Such taxes create an interaction between a bank's responses to taxes and its responses to liquidity requirements, going in both directions. The tougher liquidity requirements may lead to changes that also reduce the tax base. On the other hand, actions to reduce these taxes might include further shifts towards safer liquidity management.

\section{It does not appear that the unmodelled interactions between the different categories} would change the overall impact substantially as compared to simply adding the individual pieces. Further, the interactions tend to ameliorate the costs of each individual item. That is, the regulatory reforms provide a number of incentives to move towards safer operations, so that creating higher safety margins in one area will often automatically move a bank partway towards greater safety by other measures, reducing the cost of adjustment in that other area of regulation. Thus, the cumulative cost of the suite of regulatory reforms is probably modestly less than the sum of the parts approach.

For these reasons, the individual effects of the categories are added as the first step in estimating the aggregate costs. In addition, the interacting effects of capital and liquidity changes are also explicitly modeled. The potential impact of certain additional mitigating factors is then projected, as described next.

\section{Mitigating Factors}

Banks can respond in a number of ways to the greater regulatory burden besides raising prices or reducing credit availability, as was briefly described earlier:

- $\quad$ Absorbing the costs by lowering returns to shareholders. As discussed in the section on capital requirements, a key parameter of any regulatory cost model is an assumption about how much the increased safety will be reflected in lower return requirements from current and potential equity holders. This lies virtually entirely outside of the control of the banks and is therefore not really a bank response, but rather an automatic mitigating factor. The base case in this study assumes approximately a 50 percent pass-through, in the sense that the new required return lies halfway between the required return prior to regulatory changes and the return 
implied by the Modigliani-Miller formula. This is broadly consistent with the Modigliani-Miller approach adjusted for tax distortions and explicit and implicit guarantees for various funding sources, as described earlier.

- $\quad$ Reducing funding costs. Average funding costs are likely to rise, as the new minimum liquidity requirements push banks to shift their mix of funding towards longer-term and more reliable sources, which are consequently more expensive. Greater competition for these sources is also likely to increase their costs. These effects are explicitly modeled. Working in the opposite direction, there are two factors that should lower funding costs compared to where they would otherwise be. Greater bank safety should be rewarded with somewhat lower required rates from wholesale funding markets and there may be some room, particularly in the United States, to modestly squeeze deposit rates. ${ }^{44,45}$

- $\quad$ Reducing expenses. Industries that come under external pressure almost invariably reduce their costs as one response to the threat. A substantial portion of the cost of credit provision comes from administrative and marketing expenses, where there is considerable room to cut expenses if necessary. For American banks, roughly half the expenses represent compensation. Some of this comes down fairly automatically when pre-compensation profits fall, since the size of bonus pools tends to remain within a certain percentage range of those profits. In addition, there is almost certainly some room to cut compensation further as a percentage of profits, given the high levels of pay compared to the overall job market. It is true that some bank employees can move to other parts of the financial sector, but there is usually enough specialized human capital tied up in banking that it would take a quite substantial pay cut to trigger this for most employees. It should be noted that industry-wide compensation cuts operate differently from attempts by a single bank or a small number of banks to reduce payments. As with other industries under pressure, there is considerably less room for a competitor to try to steal employees when all institutions face the same pressures. For banks in Europe and Japan, there appear to be very considerable savings that could be achieved through restructurings or mergers, in addition to whatever room is available to cut compensation per person. Nor is compensation the only expense that could be cut in any of these regions, since few

\footnotetext{
${ }^{44}$ Investors in the wholesale market for bank funding should be willing to accept slightly lower returns as a result of the greater safety of the banks. However, these reactions may be muted by a continued belief that government aid may be available in the event a large bank becomes troubled, reducing the probability of default. To the extent that reforms have reduced this belief, the increase in perceived default risk from the reduced government backstop may more than offset the improvement in stand-alone creditworthiness.

${ }^{45}$ The United States has large deposit volumes in relation to the size of the banking system and money market funds there are becoming at least marginally less competitive as a result of regulatory changes. It is unclear whether there is room to cut deposit rates in Europe or Japan.
} 
would argue that banks are operating at their theoretical maximum efficiency in terms of real estate and other non-compensation expenses.

- $\quad$ Decreasing the expected credit losses. As explained above, there are ways that banks could modestly reduce expected credit losses, without turning away significant business, by tightening the technical terms of loans.

- $\quad$ Limiting the regulatory impacts through technical means. Banks can use various technical responses to tightened regulatory requirements, such as improving the modeling of the behavior of certain assets in order to reflect a lower level of risk in the internal risk models that determine capital requirements.

- $\quad$ Rationing credit. Credit providers could also choose to make fewer loans by rejecting those loan applications that fail to meet newly heightened credit standards. This could be done at the individual loan level or by making a decision to withdraw from lines of business that do not meet minimum profitability criteria.

- $\quad$ Raising prices for credit. Finally, of course, credit providers can simply charge more for their loans. This option will be limited by competitive market conditions within the banking industry and in regard to other types of credit providers.

- $\quad$ Restructuring their businesses. Many credit providers are in the process of rethinking what business lines they wish to be in and how they should manage those businesses. In the end, a combination of the above actions may be necessary in order to construct a portfolio of business lines that fit together to optimize the overall profitability of the organization. Such restructuring will also include strategic decisions to sell or buy businesses or to merge with other financial firms or to sell the entire organization.

The box on the following page lays out some likely areas for business restructuring and some of their implications for the financial sector and the economy as a whole. The main effect on the broader economy of the changes in business mix at the banks would be higher economic costs for non-financial companies to raise debt or hedge against financial risks, to the extent that banks do not absorb these costs by finding other efficiencies or accepting a lower return. These cost increases would have similar effects to a direct hike in the price of lending by banks.

In certain cases, there may also be a loss of some alternatives for risk hedging by nonfinancial entities. For example, some types of customized derivatives could absorb too much additional regulatory burden to be worthwhile offering on a large enough scale to support the necessary infrastructure. It is difficult to quantify the economic loss for the wider economy, since there will always be alternatives, such as less perfect hedges or simply retaining the risk at the non-financial entity.

The main effect on the larger economy from operational transformations is to hold down the cost of credit below what it would otherwise have to be. Indirectly, though, 
efficiencies mean that someone gets paid less, whether employees, through lower compensation or unemployment, or suppliers. These effects would carry through in a more complete economic model.

McKinsey (2011) and Oliver Wyman and Morgan Stanley (2011) examined the probable effects of the new regulations on capital markets activities of the banks. They found that regulatory reforms would have a major impact on profitability, primarily due to higher capital and liquidity requirements and from the business model changes being mandated for the derivatives business. However, different parts of the capital markets activities would be affected to quite different degrees. Most of the equities business remains a low user of capital and liquidity and is relatively unaffected by the derivatives changes. Both consulting firms expect this business to continue to produce very high ROE. On the other hand, much of the plain vanilla fixed income business will see significantly higher burdens from capital and liquidity requirements and was not hugely profitable in the first place. This business is likely to migrate away from firms of average or lower effectiveness and towards a relatively small number of firms that have the scale and expertise to squeeze out costs and grab market opportunities. Lessened competition and the direct pressures from the regulatory burden are likely to lead to price increases of one kind or another, whether through wider bid-ask spreads, higher commissions and fees, or in more subtle ways. 


\section{Box 1. Restructuring Strategies by Banks and Implications for the Economy}

Financial institutions can restructure themselves in a number of ways in response to regulatory and market changes. Each of these actions is likely to have a somewhat different effect on the wider economy.

Shifts in business mix. The large scale regulatory changes taking place will significantly shift the relative profitability among lines of business, and among products and customer types within various lines. Some activities will be forbidden, such as by the Volcker Rule in the United States, while others will now have regulatory burdens too high for some banks to continue to do them profitably. This could either be because the burden has increased sharply, such as would result from much higher capital requirements for certain trading activities, or because the business was only marginally profitable in the first place, so that a relatively small increase in costs may make them unattractive. The higher regulatory burden could be either a direct result of regulation, such as with capital requirements, or could be an indirect result of regulation affecting the kind of business customers demand.

Operational transformations. Higher costs should spur greater efforts to improve the efficiency of operations. Logically, there were already incentives for such improvements, since they would increase income, but there tends to be sloppiness in organizations that are making excellent profits without exerting themselves to the utmost. When external cost pressures directly threaten managers' jobs and compensation, they and their employees tend to become more inventive and more flexible. The two consulting firms write considerably about ways to use electronic information and processes to compete better. There is clearly room for improved efficiencies, even if it turns out to be less than estimated by consultants who have a stake in moving firms in that direction.

Cultural transformations. A subset of operational transformations will take place in a more subtle way, as financial firms refocus on core skills such as risk management, expense control, and meeting genuine customer needs. It is difficult to quantify these effects in any way, but they are quite likely to be beneficial for both the banks and the wider economy.

Mergers and acquisitions. Despite valid concerns about institutions that are "too big to fail," the financial industry in most countries still has many competitors of sub-optimal scale. Cost pressures will almost certainly push another wave of consolidation. In Europe, this could be enhanced still further if the twin financial and sovereign debt crises help to pull down protectionist regulatory barriers between countries in the European Union. Industry consolidation would have effects very similar to those described under "operational transformations," although likely on a larger scale for those enterprises undergoing such a change.

\section{Overall Impact of New Regulatory Initiatives on Lending rates}

\section{The overall estimated impact of the regulatory reforms analyzed here on lending rates} would be low in the long term, with relatively small economic effects. Table 14 summarizes the overall impact on lending rates of the regulatory reforms analyzed here, in the long run. As noted earlier, the effects measured here are similar to, or smaller than, the 25 bps increment that central banks usually increase or decrease their short-term policy rates. A single such adjustment is not usually regarded as significant for the economy as a whole, except for the signaling effect it provides about future central bank actions. Also, a change in central bank policy rates usually affects market rates more widely, whereas these effects are concentrated on banks in the first instance.

Nor is the size of these effects likely to be high enough to spur much reduction in credit availability. Although there will be areas of exceptions, where credit rationing might occur, 
credit price increases in this range are highly likely to be feasible for the industry as a whole, so there is no particular reason for banks to pull back in general, rather than simply to increase their pricing. This conclusion depends on the industrial structure of the financial industry, particularly whether there are alternative credit providers who could step in and steal business if bank lending rates moved in these relatively small amounts. One of the coauthors addressed this issue specifically for the United States (Elliott 2009, 2010a) and found it unlikely that competing segments could do this to any great extent. Similar logic appears to apply in Europe and Japan. Should this be wrong, the effects on the banking system would be worse, as business would be lost and more of the adjustment would fall on bank investors and employees, but the effect on the economy would be smaller. Bank credit would shrink, but non-bank credit would rise to replace it.

\section{Again, all of the analysis is based on the long-run outcome, not taking account of a transition being made in today's troubled circumstances. To the extent that bank capital or liquidity is difficult or very expensive to raise during the transition period - as they are currently in Europe, a reduction in credit supply would be expected and any increase in lending rates would be magnified, perhaps substantially. Deleveraging is clearly occurring at European banks under today's conditions in response to financial market, economic, regulatory, and political factors. It is impossible to tell whether any appreciable portion of this reaction is due to anticipation of the Basel III rules. Regardless of the transitional effects, it will be possible, over time, for banks to find the necessary capital and liquidity to provide credit, as long as the pricing is appropriate. Capital and liquidity will flow to banks from other sectors if the price of credit rises more than is justified by the fundamental underlying factors.}

As with any other industry under cost pressures, expense reduction in the banking industry will help reduce the regulatory impact. The analysis below assumes that banks are capable of reducing their expense bases by at least 5-10 percent, especially as approximately half of the expenses are compensation. Studies by management consulting firms support this belief, indeed they suggest the assumed adjustments are conservative. Further, earnings reports from financial firms, and a great deal of anecdotal evidence, show that large adjustments in expenses are already taking place. ${ }^{46}$ The cumulative impact of the various regulatory changes analyzed below is greatest in the United States, so it is assumed that a full 10 percent of expenses will be eliminated eventually there. Since the impact from regulatory reform may be less in Europe and Japan, based on the numerical analysis shown here, a more conservative 5 percent reduction is used.

The banking industry will be able to adjust in other ways, so another 5 bps of expense cuts or revenue improvements are assumed. For example, as noted in Elliott (2009), banks

\footnotetext{
${ }^{46}$ McKinsey (2010) and Oliver Wyman (2011) support this belief.
} 
in the United States compete only somewhat loosely with money market funds for deposits, leaving the industry room to reduce deposit rates slightly from what they would otherwise have paid. ${ }^{47}$ Banks may also be able to persuade customers to direct a little more of their lucrative investment banking or other business to them, in exchange for acting as their core credit providers. Even credit losses may be reduced marginally without credit rationing by modest tightening of covenants and other loan terms. Each of these actions could create economic costs for bank customers, but possibly at substantially lower levels than the gain for the banks, making them easier adjustments than pure pricing moves would be. In total, it appears quite conservative to assume that the combination of such non-price adjustment mechanisms could yield 5 bps of benefit for the banks.

Table 14. Cumulative Impact of Regulatory Reforms on Lending rates (In basis points)

\begin{tabular}{l|rrr}
\hline & Europe & Japan & U.S. \\
\hline Capital & 19 & 13 & 40 \\
Modigliani-Miller pass-through & -9 & -7 & -20 \\
Liquidity Coverage Ratio (LCR) & 8 & 1 & 11 \\
Net Stable Funding Ratio (NSFR) & 10 & 11 & 16 \\
Overlap of LCR and NSFR actions (half of smallest) & -4 & 0 & -5 \\
Derivatives & 1 & N.A. & 3 \\
Taxes and fees & 6 & 0 & 4 \\
& & & \\
Total gross effects & 31 & 18 & 48 \\
Expense cuts (at 5\% for Europe, 10\% for US) & 8 & 8 & 15 \\
Other aggregate adjustments & 5 & 3 & 5 \\
$\quad$ of which: Planned capital mitigating actions & 3 & N.A. & 2 \\
Total adjustments & 13 & 10 & 20 \\
Net cost & 18 & 8 & 28 \\
\hline Source: Tables 6 to 14. & & & \\
& & & \\
\end{tabular}

\section{All that said, there remains considerable uncertainty about the exact size of the}

regulatory impacts. The analysis here necessarily makes a number of assumptions that may turn out to be wrong, particularly in regard to the liquidity requirements, which are novel and in flux. The analysis also assumes that regulation will be implemented appropriately and not in a manner that adds unnecessary costs. It is entirely possible for badly structured regulation to substantially increase the costs of the system.

Sensitivity Analysis

\footnotetext{
${ }^{47}$ Deposit rates may go up in total, as the liquidity rules make retail deposits very attractive to banks, but they might rise by a little less in order to offset other costs. The rise in rates is already implicitly factored into the liquidity analysis, whereas any offsets are not.
} 
Changes in key parameter assumptions can have a significant impact on the estimated cost of regulatory reforms. Figure 3 shows the impact of changes in key parameter assumptions. Increases in the minimum required common equity Tier 1 capital ratio, the base $\mathrm{ROE}$, or the marginal tax rate can have an adverse effect on the lending rates while increases in the base cost of other funding sources and in the Modigliani-Miller adjustment on capital reduce costs. The first set of increases works as an additional cost to banks that needs to be covered with an increase in lending rates. The second set reduces the effect of ROE on lending rates by either replacing equity with a cheaper source of funding or by offsetting the costs of adding equity. Except for the marginal tax rate, lending rates are a linear function of key parameter assumptions. Even under extreme parameter assumptions, changes in lending rates are still lower than 100 bps. 
Figure 3. Effects of Changes in Key Parameter Assumptions on Lending Rates (In basis points)
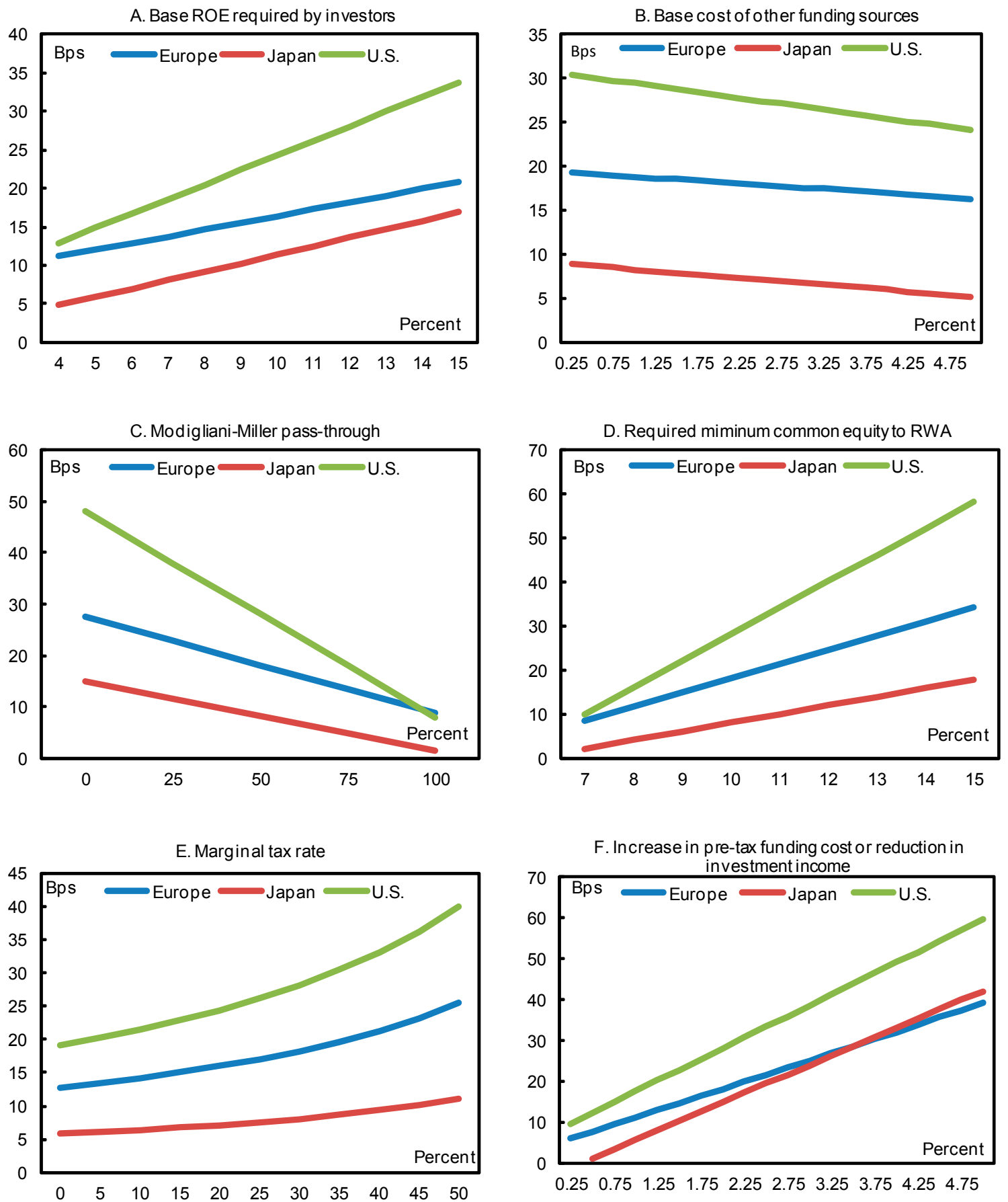

Source: Table 14 


\section{UNCERTAINTIES AND AREAS FOR FURTHER RESEARCH}

There are a number of important topics that extend beyond the scope of this paper, but would be well worth exploring with further research.

\section{Transitional Effects of Regulatory Changes}

Even though the focus of this paper is on the cost impacts in the long run, transitional costs are an important component of the adjustment process to a new regulatory regime. For instance, raising large amounts of common equity in a short period can be significantly more expensive than doing so in a long period. Similarly, it is likely that the fairly large shifts necessitated by the change in liquidity requirements could be substantially more costly if compressed into too short a period. In fact, the potential for these kinds of transitional problems lay behind the decision of the Basel Committee to establish a quite lengthy phase-in period for both capital and liquidity reforms. There will also be one-off administrative costs of various kinds to make the transition from one regulatory regime to another. It would be worthwhile to extend the quantitative analysis from this paper to take into account transitional as well as long-term effects.

\section{Impact of Regulatory Arbitrage}

There is clearly the potential for more lightly-regulated jurisdictions and market sectors to take business away from banks and more highly-regulated institutions. This is a real possibility and this study has also included brief descriptions of how the industry and markets would respond. However, there is considerably more that could usefully be done to examine the potential for regulatory arbitrage in a more focused manner.

\section{Impact of Less-Regulated Credit Providers}

It would be particularly worthwhile to look in detail at how "shadow banks" might target parts of the traditional banking business. For instance, there is a strong economic demand for maturity transformation services that will become substantially more expensive for traditional banks to fulfill as the new liquidity rules push them to increase the maturity of their liabilities and reduce the term of their assets. Money market funds in the United States have demonstrated that an entity need not necessarily have deposit insurance protection in order to appear safe enough to persuade bank depositors to shift funds from banks to these new quasi-deposit arrangements. Structured Investment Vehicles did a version of the same thing, albeit taking in their money on a wholesale basis and operating with a business model that is unlikely to be revived anytime soon. Nonetheless, they flourished for quite a number of years, as did a number of other types of shadow banking activity. 


\section{Effects on Additional Regions of the World}

This study focused only on the United States, Europe as a whole, and Japan, due to data limitations and resource constraints. It would be useful to break Europe down into at least Continental Europe, the United Kingdom, and Switzerland, given the quite different paths being taken in the United Kingdom and Switzerland on some important regulatory issues. Major emerging market financial powers are also worthwhile to examine in detail given how different their situations are from the more developed countries in this report and the high probability that their market shares of global financial activity will rise over time.

\section{Quantitative Estimates for Additional Categories of Reform}

This study only examined five of the most significant areas of financial regulatory reform, one of which, securitization, proved impossible to quantify. The others shown in the qualitative analysis would also be worth further consideration, although they would be more difficult to analyze quantitatively.

\section{Translating Credit Effects to Impacts on Economic Output}

This study stops at the estimation of effects on credit provision, but policymakers are most interested in the effects on economic output. It would be very useful to take the next step in the analysis.

\section{Conclusion}

Financial reform comes at a price. Higher safety margins, particularly in terms of greater capital and liquidity, do add operating costs for lenders. Those costs will be passed on, at least partially, to the wider economy. Lending rates appear likely to rise by $17 \mathrm{bps}$ in Europe, 8 bps in Japan, and 26 bps in the United States, according to the base case developed here. There is considerable uncertainty about the true cost levels, but the sensitivity analysis demonstrates that reasonable changes in assumptions would not dramatically alter the base case conclusions

important limitations to the analysis presented here. Transition costs are not examined, a number of regulatory reforms are not modeled, judgment has been required in making many of the estimates, the overall modeling approach is relatively simple, and regulatory implementation is assumed to be appropriate, not creating unnecessary costs. Despite these limitations, the results appear to be a balanced, albeit rough, assessment of the likely credit costs. In addition, the results are also broadly in line with previous studies from the official sector, partially because similar methodologies are employed. This paper finds similar firstorder effects to those from the official BIS assessments of Basel III (BCBS (2010) and MAG (2010)) and the analysis at the OECD by Slovik and Cournède (2010). 


\section{Three extensions of the methodologies from the official studies, though, lead to} substantially lower net economic costs. The base case figures in Table 14 show increases in lending rates of roughly a third to a half of those found in the BIS and OECD studies, despite important common modeling approaches between all of these studies. First, the baselines chosen here assume a greater increase in safety margins due solely to market forces, and therefore less of a regulatory effect, than the OECD study and certainly than the industrysponsored IIF study. ${ }^{48}$ Industry actions through end 2010 suggest that market forces alone would have produced reactions to that point similar to what was witnessed, even if no regulatory changes were contemplated. Second, this paper explicitly assumes that banks will react by reducing costs and taking certain other measures that have little or no effect on credit prices and availability, in addition to the actions assumed in the other studies. The official studies do not assume expense cuts and other adjustments of this type and the IIF study assumes a fairly low level of change. This accounts for $13 \mathrm{bps}$ in Europe, and $10 \mathrm{bps}$ in Japan, 20 bps of cost reduction in the United States. Third, this paper explicitly assumes that equity investors will reduce their required rate of return on bank equity as a result of the safety improvements. Debt investors are assumed to follow suit, although to a much lesser extent. For conservatism, the official studies assume zero benefit from investor reactions and the IIF study essentially assumes that these benefits, although real, will arise over a longer time-frame than is covered by their projections.

The relatively low levels of economic costs found here strongly suggest that the benefits in terms of less frequent and less costly financial crisis would indeed outweigh the costs of regulatory reforms in the long run, although this paper does not attempt to estimate the economic benefits of the regulatory changes. Put another way, banks around the world appear to have a considerable ability to adapt to the regulatory changes without radical actions that would harm the wider economy.

There is a great deal of additional work that would be helpful in confirming and expanding these conclusions, as noted in Section V. Financial systems are complex and so are the reform measures.

\footnotetext{
${ }^{48}$ The BIS studies do not reach firm conclusions on the additional capital needs, but rather calibrate the cost for different levels of increase.
} 
APPENDIX I. SUPPLEMENTARY TABLES

Table 15. Impact of Major Regulatory Initiatives on European and Japanese Financial Institutions

A. Europe

\begin{tabular}{|c|c|c|c|c|c|c|c|}
\hline & \multicolumn{2}{|c|}{ Commercial Banking } & \multirow{2}{*}{$\begin{array}{c}\text { Investment } \\
\text { Banking }\end{array}$} & \multirow{2}{*}{$\begin{array}{l}\text { Universal } \\
\text { Banking }\end{array}$} & \multirow{2}{*}{$\begin{array}{c}\text { Life } \\
\text { Insurers }\end{array}$} & \multirow{2}{*}{$\begin{array}{l}\text { Non-bank } \\
\text { Financials }\end{array}$} & \multirow{2}{*}{$\begin{array}{r}\text { Capital } \\
\text { Markets }\end{array}$} \\
\hline & Large & Small & & & & & \\
\hline Higher capital requirements & 10 & 10 & 10 & 10 & -2 & -8 & -10 \\
\hline Higher liquidity requirements & 10 & 10 & 10 & 10 & -4 & -6 & -10 \\
\hline Tightening of derivatives regulation & 5 & 2 & 10 & 7 & -2 & -3 & -4 \\
\hline Accounting changes & 2 & 2 & 2 & 2 & 1 & 4 & 2 \\
\hline Changes to securitization regulation & 2 & 2 & 2 & 2 & 1 & 4 & 3 \\
\hline Enhanced consumer protection regulation & 2 & 1 & 1 & 2 & 1 & 4 & 1 \\
\hline Expansion of the regulatory perimeter & -1 & -1 & -1 & -1 & 0 & 4 & 1 \\
\hline Higher taxes or fees facing financial institutions & 3 & 2 & 3 & 3 & 1 & 3 & -1 \\
\hline Changes in crisis management and resolution regimes & 4 & 3 & 3 & 3 & -1 & -1 & -2 \\
\hline Tougher regulation of credit rating agencies & 1 & 1 & 1 & 1 & 1 & 2 & 2 \\
\hline Structural changes to banks and activity limits & 1 & 0 & 1 & 1 & 0 & 0 & 0 \\
\hline Changes in regulation of compensation and governance & 1 & 0 & 2 & 2 & 0 & -1 & -1 \\
\hline
\end{tabular}

B. Japan

\begin{tabular}{|c|c|c|c|c|c|c|c|}
\hline & \multicolumn{2}{|c|}{ Commercial Banking } & \multirow{2}{*}{$\begin{array}{c}\text { Investment } \\
\text { Banking }\end{array}$} & \multirow{2}{*}{$\begin{array}{l}\text { Universal } \\
\text { Banking }\end{array}$} & \multirow{2}{*}{$\begin{array}{c}\text { Life } \\
\text { Insurers }\end{array}$} & \multirow{2}{*}{$\begin{array}{l}\text { Non-bank } \\
\text { Financials }\end{array}$} & \multirow{2}{*}{$\begin{array}{r}\text { Capital } \\
\text { Markets }\end{array}$} \\
\hline & Large & Small & & & & & \\
\hline Higher capital requirements & 10 & 10 & 10 & 10 & -5 & -5 & -10 \\
\hline Higher liquidity requirements & 5 & 4 & 10 & 6 & -5 & -5 & -8 \\
\hline Tightening of derivatives regulation & 5 & 2 & 10 & 7 & -2 & -3 & -4 \\
\hline Accounting changes & 2 & 2 & 2 & 2 & 1 & 4 & 2 \\
\hline Changes to securitization regulation & 2 & 2 & 2 & 2 & 1 & 4 & 3 \\
\hline Enhanced consumer protection regulation & 1 & 1 & 1 & 1 & 1 & 3 & 1 \\
\hline Expansion of the regulatory perimeter & -1 & -1 & -1 & -1 & 0 & 4 & 1 \\
\hline Higher taxes or fees facing financial institutions & 3 & 2 & 3 & 3 & 1 & 3 & -1 \\
\hline Changes in crisis management and resolution regimes & 2 & 2 & 3 & 2 & -1 & -1 & -2 \\
\hline Tougher regulation of credit rating agencies & 1 & 1 & 1 & 1 & 1 & 2 & 2 \\
\hline Structural changes to banks and activity limits & 1 & 0 & 1 & 1 & 0 & 0 & 0 \\
\hline Changes in regulation of compensation and governance & 1 & 0 & 1 & 1 & 0 & 0 & 0 \\
\hline
\end{tabular}


Table 16. European, Japanese, and U.S. Banks in the Sample

1-European banks
1.1-European investment banks
Barclays
Credit Suisse
Deutsche Bank
UBS
1.2-European universal banks
BNP
BPCE
Commerzbank
Credit Agricole Group
HSBC
ING
KBC
RBS
Société Générale
Standard Chartered

1.3-European commercial banks

Alpha bank

Banco Popular Español

Bank of Cyprus

Bank of Ireland

BBVA

BMPS

Danske

Dexia

DnB NOR

EFG

Erste

Handelsbanken

Intesa

La Caixa

Lloyds Group

NBG

Nordea

Piraeus

Raiffeisen Bank International AG

Sabadell

Santander

SEB

Swebank

UniCredit
2-Japanese banks

2.1-Japanese investment banks

Nomura

2.2-Japanese universal banks

Mizuho

MUFG

Resona

Shinsei

Sumitomo Holdings

3-U.S. banks

3.1-U.S. investment and trust banks

Bank of New York

Goldman Sachs

JPMorgan

Morgan Stanley

State Street

3.2-U.S. universal banks

Bank of America

Citigroup

3.3-U.S. commercial banks

American Express

BB\&T Corporation

Capital One Financial Group

COMERICA

Fifth Third Bancorporation

Huntington Bancshatres

Keycorp

M\&T Bank

Northern Trust

PNC

Regions Financial Corporation

SunTrust Banks

U.S. Bancorp

Wells Fargo 
Table 17. Planned De-Risking Measures, End-2010

\begin{tabular}{|c|c|}
\hline Country & Planned de-risking measures \\
\hline \multicolumn{2}{|l|}{ European banks } \\
\hline Alpha Bank & Loan deleveraging. \\
\hline Banco Popular Español & IRB Model optimization, RWA improvements and others. \\
\hline Bank of Ireland & $\begin{array}{l}\text { Wind-down and disposal of non-core loan portfolios and through repayments/redemptions in non-core book. They include portfolios of U.K. } \\
\text { Intermediary sourced residential mortgage; selected international niche businesses such as project finance, asset based lending and certain } \\
\text { international corporate banking portfolios; certain international commercial investment property portfolios; and certain land and development loans. }\end{array}$ \\
\hline Barclays & $\begin{array}{l}\text { Sale of legacy assets and other management actions including hedging of counterparty exposures and tail risks, selling down the correlation book, } \\
\text { and continued model refinement. }\end{array}$ \\
\hline BBVA & RWA optimization and asset and portfolio management. \\
\hline BMPS & Optimization of RWAs, product company structure, and real estate portfolio. \\
\hline BNP & $\begin{array}{l}\text { Asset repricing, strict origination policies for short-term facilities and medium-term loans, asset sales and business disposals. Downsize of } \\
\text { mortgage specialized businesses (Hungary, the Netherlands, Norway, Spain, and Switzerland) and brokers' activity in France and exit from leasing } \\
\text { non-core activities (real estate leasing, specific asset leasing, etc.) and subscale countries (the United Kingdom, Hungary, Switzerland). }\end{array}$ \\
\hline BPCE & Asset disposal, CVA optimization. \\
\hline Commerzbank & $\begin{array}{l}\text { Central clearing of OTC derivatives and adjusted framework for hedging counterparty risk. Accelerated reduction of prolongatinon rates and natural } \\
\text { portfolio wind-down in the asset based finance unit and restructuring and sale of assets in in the portfolio restructuring unit. }\end{array}$ \\
\hline Credit Agricole Group & $\begin{array}{l}\text { Run-off of discontinuing operations through natural amortization of outstanding loans and active management positions, potential asset disposals, } \\
\text { and optimization of RWAs. Withdrawal from businesses in equity derivatives and commodities. }\end{array}$ \\
\hline Credit Suisse & $\begin{array}{l}\text { Reduction of fixed income RWAs by accelerating exit from low revenues long-dated and unsecured trades in foreign exchange rates, selling/running } \\
\text { off low rated positions in securitized products, right-sizing investment grade positions in credit products, focusing on executing flow-based model in } \\
\text { larger emerging markets, optimizing towards private banking client demand in commodities, and acceleration of wind-downs. }\end{array}$ \\
\hline Deutsche Bank & $\begin{array}{l}\text { Sale, unwind, run-off, hedging, and optimization of securitizations, correlation trading, trading book exposures to certain emerging market } \\
\text { sovereigns, and uncollateralized derivatives exposures (shift to OTC derivatives towards central clearing), with limited dependency on sales. }\end{array}$ \\
\hline Dexia & Asset disposals and sale of Dexia banka Slovenko, DenizEmeklilik, Dexia Crediop, and Dexia Sabadell. \\
\hline Eurobank & Liability management, IRB methodology, deleveraging and de-risking in Greece, Tekfen strategic sale, other (net of PSI impact). \\
\hline HSBC & $\begin{array}{l}\text { Reduction of non-core portfolios and legacy positions (for instance, in HSBC Finance Corporation and GB\&M), correlation books, CVA and market } \\
\text { risk mitigation, and resecuritization actions. Actions improving capital allocation include expanding in attractive markets, turnaround efforts, increase } \\
\text { in efficiency, and disposals and closure of non-strategic business (retail banking in Russia). }\end{array}$ \\
\hline ING & Sale of Real Estate Investment Management businesses in the US, Europe, and Asia. \\
\hline Intesa & $\begin{array}{l}\text { Active capital allocation including sale of the remaining } 25 \% \text { of Findomestic, Cassa di Risparmio della Spezia, and } 96 \text { branches to Crédtit Agricole } \\
\text { Group, and the aquisition of control of Banca Monte Parma; optimization of sources and uses of capital (eg., extension of internal models, and } \\
\text { gradual disposal of unprofitable assets. }\end{array}$ \\
\hline KBC & $\begin{array}{l}\text { Mitigation consisting of selling Kredyt Bank and Wart in Poland, limiting international lending and capital market activities (sale of German corporate } \\
\text { activities, Diamond Financing, international leasing, global trade and project finance), divesting European Private Banking, complementary channels } \\
\text { in Belgium (Fidea) and non-EU CEE countries (Russia and Serbia) and accelerated sale or unwinding of selected ABS and CDO assets. }\end{array}$ \\
\hline Lloyds & Run-off of non-core assets, including treasury and customer assets (commercial real estate, wholesale, wealth and international, and retail). \\
\hline NBG & $\begin{array}{l}\text { Use of collective provisions, release of excess provisions in Turkey as asset quality improves, Finansbank stake offering, balance sheet } \\
\text { management, deleveraging, sale of non-core assets and other actions. }\end{array}$ \\
\hline Nordea & $\begin{array}{l}\text { Credit portfolio management (portfolio composition reviews, capital efficient products, improved transparency on profitability, netting and collateral } \\
\text { agreements) and models and process refinements (advanced IRB roll-out; foundation IRB for Standardized portfolios; internal models for counterparty } \\
\text { credit risk; sourcing and treatment of collaterals and guarantees, and refining and improving credit processes). }\end{array}$ \\
\hline RBI & Further run-down of remaining non-core financial institutions and sovereigns loan portfolio. \\
\hline RBS & $\begin{array}{l}\text { Run-off, impairments, and asset disposals and closures of undrawn commitments and non-core assets consisting of commercial real estate, } \\
\text { markets, retail, corporates, SMEs, and others. }\end{array}$ \\
\hline Santander & Deleveraging in mature markets. \\
\hline Société Générale & $\begin{array}{l}\text { Run-off and disposal of legacy assets (CDOs, RMBS and CMBS) and selected structured lending portfolios. Possible additional optimization of } \\
\text { market RWAs (active management of counterparty risk), optimization of portfolio of activities, and releasing goodwill and RWAs. }\end{array}$ \\
\hline Swedbank & Deleveraging in Baltic countries. \\
\hline UBS & $\begin{array}{l}\text { Reduction of investment bank assets by scaling down investment bank, CVA mitigation and optimization, reducing securitization, moving OTC } \\
\text { derivatives to CCPs, hedging, reducing student loan auction rate securities and sales and restructuring of other legacy assets. }\end{array}$ \\
\hline UniCredit & Migration of OTC derivatives to exchanges, portfolio optimization, capital management, and other mitigating actions. \\
\hline \multicolumn{2}{|l|}{ Japanese banks } \\
\hline Shinsei & $\begin{array}{l}\text { RWA optimization, reduction of capital deductions through disposal and run-off of non-core assets, including real estate equity investment, asset- } \\
\text { backed investment/securities, CLO/ACPM/CFI, housing loan warehousing, etc. }\end{array}$ \\
\hline \multicolumn{2}{|l|}{ U.S. banks } \\
\hline Bank of America & $\begin{array}{l}\text { Wind-down of proprietary trading, reduction in high RWA positions, reduction of equity exposures, reduction of low-quality investments subject to } \\
\text { deduction under Basel III, run-off of loan portfolio (excluding GNMA repurchases), and other measures including mitigation of counterparty and CVA } \\
\text { exposures. }\end{array}$ \\
\hline Bank of New York & Quarterly paydown of sub-investment grade securities. \\
\hline Goldman Sachs & Roll-offs of the correlation book and the ratio rate of mortgages and securitizations. \\
\hline Morgan Stanley & Run-off of existing inventory and new mitigation opportunities such as scheduled takedown of new inventory. \\
\hline PNC & Paydown of 30 percent of sub-investment grade securities. \\
\hline
\end{tabular}




\section{APPENDiX II. Assumptions For The CREDIt Pricing EQUATION}

Marginal tax rate: A 30 percent rate was used for the United States, based on the analysis in Elliott (2009). This assumes that tax management techniques reduced the effective marginal rate somewhat below the statutory 35 percent federal rate plus applicable state taxes. 30 percent was also used for Europe based on Kopp et al. (2010) and Schanz et al (2011) for the United Kingdom. The effective statutory tax rate for Japan is currently higher, but it is assumed that tax management techniques lower this to 30 percent.

Minimum ratio of capital to RWA: This is explained in the text related to Table 7.

RWA as a percentage of total assets: This is taken from company reports in the sample and assumed to remain constant at end-2010 levels.

Required return on equity (ROE): As discussed in the body, the ROE in the loan pricing equation is 12 percent for European and U.S. banks. For Japanese banks, it is 7 percent.

Base cost of other funding sources: This is a rough estimate of the weighted cost of deposits and debt funding in equilibrium, some years hence. As such it is necessarily quite imprecise. Rates are assumed to be higher than the present historically low levels that have resulted from the financial crisis, ensuing severe recession, and resulting policy actions.

Administrative expenses: For Europe, this is based on Kopp et. al. (2010). For the United States, this is based on Elliott (2009). This figure is somewhat difficult to calculate since it requires the allocation of total costs to lending and to other activities. For example, noninterest expense at United State's banks is much higher than $150 \mathrm{bps}$, but much of this is directly related to insurance brokerage and other activities which do not involve lending and which bring in higher levels of related income. Fortunately, the imprecision here is only tangentially relevant to the analysis, since it does not affect the marginal cost of the regulatory changes. The one impact is that it influences the authors' estimates of how much expenses could be cut in response to the cost pressures on the banking industry.

Base liquidity gap: Taken from Table 8.

Percentage of capital that replaces short-term funding: For illustrative simplicity, the marginal cost calculation for capital requirements assumes that additional capital replaced other funding sources pro rata. Therefore, a portion of short-term funding was replaced with capital, which counts as longer-term funding for the LCR and NSFR calculations. It is assumed that 30 percent of the additional capital replaces short-term funding.

Increase in pre-tax funding cost or reduction in investment income: This represents the increased cost of shifting from short-term to long-term funding sources or the decreased 
investment earnings from switching from less liquid or longer-term assets to more liquid or shorter-term assets. As shown in Abouhossein (2011), European banks have multiple avenues to adjust their asset and liability portfolios. That analysis showed that the more expensive, but more likely, methods would cost modestly more than 200 bps. The exact 200 bps reduction in interest margin for Europe and the United States in Table 9 is based on the assumption that some of the adjustment would be done with cheaper methods. As noted in the body, BCBS (2010) assumes a 100 bps difference in short-term and long-term interest rates based on historical figures. For Japan, an adjustment cost of $125 \mathrm{bps}$ is used. Kato et. al. (2010) suggests a significantly lower cost would exist currently, but it is assumed here that this would be higher in equilibrium, as rates and related spreads likely resume more normal long-term patterns.

Reduction in interest margin as percentage of total assets: Since no sources provided a breakdown of the liquidity gaps between lending and other activities, the costs of meeting the LCR and NSFR requirements is assumed to be spread evenly across the full range of bank activities.

Cost of derivatives changes: Taken from Table 11.

Cost of new tax and fee measures: Taken from Table 12. Taxes and fees are assumed not to be tax-deductible and therefore need to be offset by after-tax income from other sources.

Cost per dollar of assets, for derivative reforms and tax changes: The costs are assumed to be spread evenly across the full range of bank activities. 


\section{REFERENCES}

Abouhossein, K. (2010a), European Banks - Regulatory Fears now Over-discounted, JP Morgan Europe Equity Research (London).

— (2010b), Global Investment Banks - Dodd/Lincoln Bill Analysis : Implications for the Structure of the IB Industry, JP Morgan Europe Equity Research (London).

- (2011), All Eyes on Funding: LCR, the Next Undiscounted Headwind, JP Morgan Europe Equity Research (London).

— the Patch to an Acceptable ROE for Tier I and III Players, JP Morgan Global Equity Research (London).

Acharya, V., Colley, T., Richardson, M., and Walter, I. (2011), Dodd-Frank One Year Ago (London: Centre for Economic Research).

Admati, A.R., DeMarzo, P.M. ,Hellwig, M.F., and Pfleiderer, P. (2011), “Fallacies, Irrelevant Facts, and Myths in the Discussion of Capital Regulation: Why Bank Equity Is not Expensive?," Working Paper (Stanford, CA: Rock Center for Corporate governance at Stanford University).

Amom, P. (2011), Dodd-Frank Act: Assessing the Regulation, Sungard (Wayne).

Anderson, D., Buehler, K., Ceske, R., Ellis, B., Samandari, H., and Wilson, G. (2011), "Assessing and Addressing the Implications of New Financial Regulations for the U.S. Banking Industry,” McKinsey Working Papers on Risk, 25 (New York).

Association for Financial Markets in Europe (2010), The Systemic Safety Net: Pulling Failing Firms Back From the Edge (London).

Bank for International Settlements (BIS, 2010), Proposal to Ensure the Loss Absorbency of Regulatory Capital at the Point of Non-Viability, BCBS Consultative Document (Basel).

— , (2011), "Fixed Income Strategies of Insurance Companies and Pension Funds," CGFS Papers, No. 44 (Basel).

Basel Committee on Banking Supervision (BCBS, 2010), An Assessment of the Long-Term Economic Impact of Stronger Capital and Liquidity Requirements (Basel: Bank of International Settlements). 
_- (2012), Results of the Basel III Monitoring Exercise as of 30 June 2011 (Basel: Bank of International Settlements).

Belton, T. (2011), The Domino Effect of a U.S. Treasury Technical Default, JP Morgan U.S. Fixed Income Strategy (New York).

Cannon. F., McGratty, C., Kleinhanzl, B., and Konrad, D. (2010), Our First Go at Basel III for the BKX, The BKX Monthly: Large Cap Banks (New York).

Chan-Lau, J.A. (2011), "Capital Requirements, Leverage Ratio, Countercyclical Buffers, and Dynamic Provisions," in "Policy Instruments to Lean Against the Wind in Latin America," by G. Terrier et al. IMF Working Paper 11/159 (Washington: International Monetary Fund).

Choulet C. (2011), Dodd-Frank Act: U.S. Vision of Financial Regulation, BNP Paribas Economic Research (Paris).

Claessens, S., Keen, M., and Pazarbasioglu, C. (2010), "Financial Sector Taxation: The IMF's Report to the G-20 and Background Material," (Washington: International Monetary Fund).

Da Silva, C. A., Goel, A., and O'Donohoe, N. (2010a). Global Banks—Too Big to Fail? A Review of Regulatory Proposals, JP Morgan Global Equity Research (London).

—_, (2010b). Global Banks—Too Big to Fail? Big Can (also) Be Beautiful, JP Morgan Europe Equity Research (London).

—, (2010c). Global Banks—Too Big to Fail? Running the Numbers, JP Morgan Europe Equity Research (London).

—, (2010d). Global Banks—Too Big to Fail? Regulation -A clearer Pictures Emerges, JP Morgan Global Equity Research (London).

—_, (2011). European Banks: The Lost Decade, Credit Suisse Equity Research (London).

Davis, Polk (2011), Dodd-Frank Progress Report (New York).

Dayal, R., Grasshoff, G., Jackson, D., Morel, P., and Neu, P. (2011), Facing New Realities in Global Banking, The Boston Consulting Group Risk Report 2011 (Boston). 
De Ramon, S., Iscenko, Z., Osborne, M., Straughan, M., and Andrews, P. (2012), Measuring the Impact of Prudential Policy on the Macroeconomy: A Practical Application to Basel III and Other Responses to the Financial Crisis, Occasional Paper Series, No. 42, (London: Financial Services Authority).

Deloitte (2011), "Central Clearing for OTC Derivatives Impact on OTC Revenues-What Can You Expect beyond Compression?," Perspectives on Financial Reform, No. 4 (New York).

Elliott, D.J. (2009), Quantifying the Effects of Lending Increased Capital Requirements (Washington: The Brookings Institution), http://www.brookings.edu/papers/2009/0924_capital_elliott.aspx.

(2010a), A Further Exploration of Bank Capital Requirements: Effects of Competition from Other Financial Sectors and Effects of Size of Bank or Borrower and of Loan Type, (Washington: The Brookings Institution), http://www.brookings.edu/ /media/Files/rc/papers/2010/0129_capital_elliott/0129 ca pital_requirements_elliott.pdf.

(2010b). A Primer on Bank Capital, The Brookings Institution, (Washington: The Brookings Institution), http://www.brookings.edu/ /media/Files/rc/papers/2010/0129_capital_elliott/0129_ca pital primer elliott.pdf.

(2010c), Financial Reform: Now It's up to the Regulators, (Washington: The Brookings Institution), http://www.brookings.edu/papers/2010/0712 regulators_elliott.aspx.

- (2010d), The Danger of Divergence: Transatlantic Cooperation on Financial Reform, (Washington: Atlantic Council), http://www.brookings.edu/reports/2010/1007_atlantic_council_elliott.aspx.

— Salloy, S., and Santos, A.O. (2012), "Assessing the Costs of Financial Regulation," IMF Working Paper, forthcoming (Washington: International Monetary Fund).

Elmendorf, D.W. (2011), “Review of CBO's Cost Estimate for the Dodd-Frank Wall Street Reform and Consumer Protection Act," statement before the Subcommittee on Oversight and Investigations (Washington: Committee on Financial Services of the U.S. House of Representatives).

European Banking Authority (EBA, 2012), Results of the Basel III Monitoring Exercise as of 30 June 2011 (London). 
Flannery, Mark J. (2010), "What to do about TBTF?," paper presented at the Federal Reserve Bank of Atlanta 2010 Financial Markets Conference-Up From the Ashes: The Financial System After the Crisis, Atlanta, May 12.

—_, (2009), "Stabilizing Large Financial Institutions with Contingent Capital Certificates," (unpublished; Gainesville: University of Florida).

Financial Stability Oversight Report (2011), Annual Report (Washington: Treasury Department).

Goldberg, J., Blyakher, I., Keating, M., and Nash, R. (2010) (2010). Large-cap/Mid-Cap Banks 1Q10 10-QReview-Quantifying the Regulatory Impact, Barclays Capital Equity Research America (New York).

Gorton, G., Lewellen, S., and Metrick, M. (2011), “The Cost of Bank Capital: Thinking beyond Modigliani and Miller” (unpublished; New Haven: Yale University).

Haldane, A., Brennan, S., and Madouros, V. (2010). "What Is the Contribution of the Financial Sector: Miracle or Mirage?" in The Future of Finance: The LSE Report by A. Turner et al. (London: London School of Economics and Political Science).

Hansen, M., Moss, J., Grossman, R., and Murray, A. (2012), Basel III: Return and Deleveraging Pressures, Fitch Ratings Macro-Credit Research (New York).

Heller, D., and Vause, N. (2012), "Collateral Requirements for Mandatory Central Clearing of Over-The-Counter Derivatives,” BIS Working Papers, 373 (Basel: Bank for International Settlements).

Herring, R.J., and Calomiris, C.W. (2011), "Why and How to Design a Contingent Convertible Debt Requirement," (unpublished; Philadelphia: University of Pennsylvania and New York: Columbia Univerisity).

Horowitz, K., Foundos, S., Ketron, G., and Fandetti, D. (2010), U.S. Financials: Regulatory Reform Update-Assessing EPS Impact in an Uncertain Environment, Citigroup Global Markets (New York).

Institute of International Finance (2011), The Cumulative Impact on the Global Economy of Changes in the Financial Regulatory Framework (Washington).

International Monetary Fund (2011), Global Financial Stability Report, April (Washington). 
Kato, R., Kobayashi, S., and Saita, Y. (2010), "Calibrating the Level of Capital: The Way We See It,” Bank of Japan Working Paper Series, 10-E-6 (Tokyo).

King, M. R. (2010), "Mapping Capital and Liquidity Requirements to Bank Lending Spreads,” BIS Working Papers, 324 (Basel: Bank for International Settlements).

Kono, A. (2010), Update on Global Financial Regulation-U.S. Banks Face Largest Earnings Impact, JP Morgan Japan Equity Research (Tokyo).

Kopp, E., Ragacs, C., and Schmitz, S. (2010), The Economic Impact of Measures Aimed at Strengthening Bank Resilience-Estimates for Austria, Financial Stability Report, 20 (Vienna: Oesterreichische National Bank), pp 86-114.

LeLesle, V., and Avramova, Sofiya, "Revisiting Risk-Weighted Assets," IMF Working Paper, 12/90 (Washington: International Monetary Fund).

Macroeconomic Assessment Group (MAG, 2010), Assessing the Macro-Economic Impact of the Transition to Stronger Capital and Liquidity Requirements, (Basel: Bank of International Settlements).

Miles, D., Yang, J., and Marcheggiano, G. (2011), “Optimal Bank Capital,” External MPC Unit Discussion Papers, 31 (revised and extended version), (London: Bank of England).

Modigliani, F., and Miller, M.H. (1958), "The Cost of Capital, Corporation Finance, and the Theory of Investment," American Economic Review, Vol. 48, No. 3, pp. 261-97.

Morgan Stanley and Oliver Wyman (2011), Wholesale \& Investment Banking OutlookReshaping the Model, Morgan Stanley Research Global (New York).

Moszkowki, G., Goldschneider, S., and Chubak, S., (2010), FinReg Update: Senate Version likely to Dominate, Bank of America-Merrill Lynch Industry Overview (New York).

Myers, S. (1984), “The Capital Structure Puzzle,” Journal of Finance, Vol. 39, No. 3, pp. 573-92.

—_ and Majluf, N. (1984), "Corporate Financing and Investment Decisions When Firms Have Information That Investors Do Not Have," Journal of Financial Economics, No. 13, pp. 187-221.

Nozaki, H., and Saito, K. (2011), Basel Primer (4 ${ }^{\text {th }}$ Edition), Citigroup Global Markets Japan Inc. (Tokyo). 
Otker-Robe, I., and Pazarbasioglu, C. (2010), "Impact of Regulatory Reforms on Large and Complex Financial Institutions," IMF Staff Position Note, 10/16 (Washington: International Monetary Fund).

Ötker-Robe, I., Narain, A., Ilyina, A., and Surti, J. (2011), The Too-Important-to-Fail Conundrum: Impossible to Ignore and Difficult to Resolve, IMF Staff Discussion Note, 11/12 (Washington: International Monetary Fund).

Quigon, L. (2011), Basel III: No Achilles'Spear, BNP Paribas Economic Research (Paris).

Roger, S., and Vlcek, J. (2011), "Macroeconomic Cost of Higher Bank Capital and Liquidity Requirements," IMF Working Paper, 11/103 (Washington: International Monetary Fund).

Samuels, S., Harrison, M., and Rajkotia, N. (2012), Bye Bye Basel? Making Basel More Relevant, Barclays Equity Research (London).

Schanz, J., Aikman, D., Collazos, P., Farag, M., Gregory, D., and Kapadia, S. (2011), The Long-Term Economic Impact of Higher Capital Levels, BIS Papers, 60 (Basel: Bank of International Settlements), pp. 73-81.

Slovik, P., and B. Cournède (2011), "Macroeconomic Impact of Basel III," OECD Economics Department Working Papers, 844 (Paris: Organisation for Economic Cooperation and Development).

Schröder, M., Riedler, J., Jaroske, L., and Lang, G. (2011), Assessment of the Cumulative Impact of Various Initiatives on the European Banking Sector, European Parliament, Directorate-General for Internal Policies, Policy Department A: Economic and Scientific Policy, IP/A/ECON/ST/2010-21 (Brussels).

Singh, M. (2010), "Collateral, Netting, and Systemic Risk in the OTC Derivatives Market," IMF Working Paper, 10/99 (Washington: International Monetary Fund).

Tamura, S., and Tani, M. (2009), Japan's Major Banks: Industry Overview, Barclays Capital Equity Research (London).

The Clearing House Association (2011a), How Much Capital Is Enough? Capital Levels and G-SIB Capital Surcharges (Washington).

— , (2011b), The Basel III Liquidity Framework: Impacts and Recommendations (Washington). 
Van Steenis, H., and others (2011), Investment Banks: Basel III Transforms Returns, Models, and Advantages, Morgan Stanley Research Europe (London).

Visalli, S., Roxburgh, C., Daruvala, T., Dietz, M., Lund, S., and Marrs, Anna (2011), The State of Global Banking - In Search of a Sustainable Model, McKinsey Annual Review on the Banking Industry (New York). 